OOD

A.UES

OCKE:

64

1025 


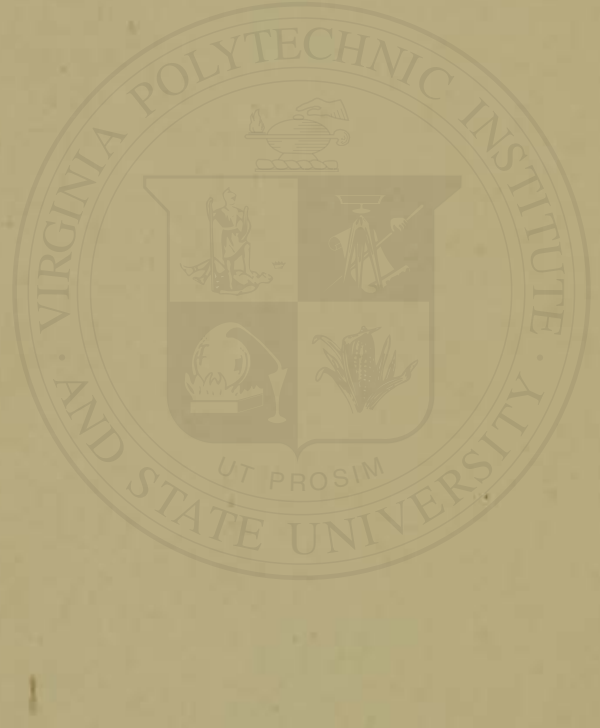





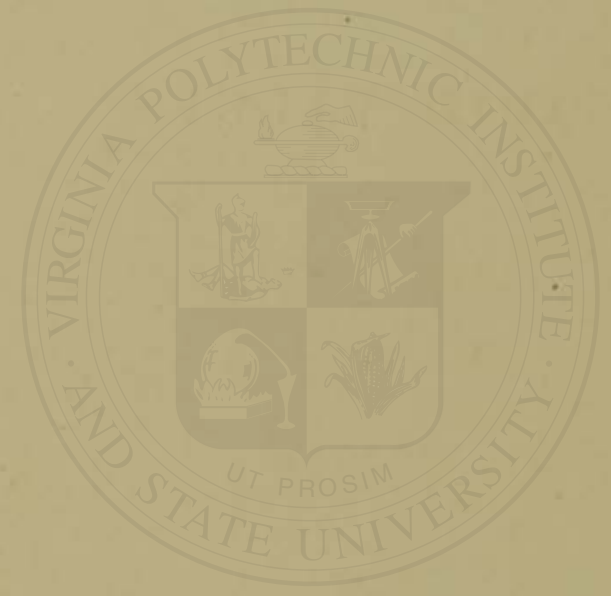




\section{FOOD VALUES}

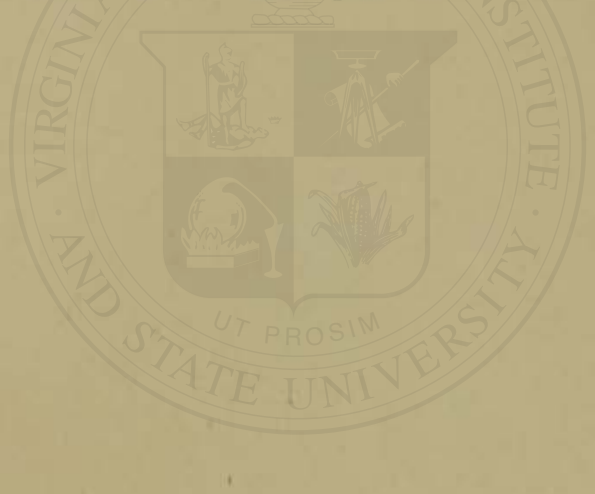




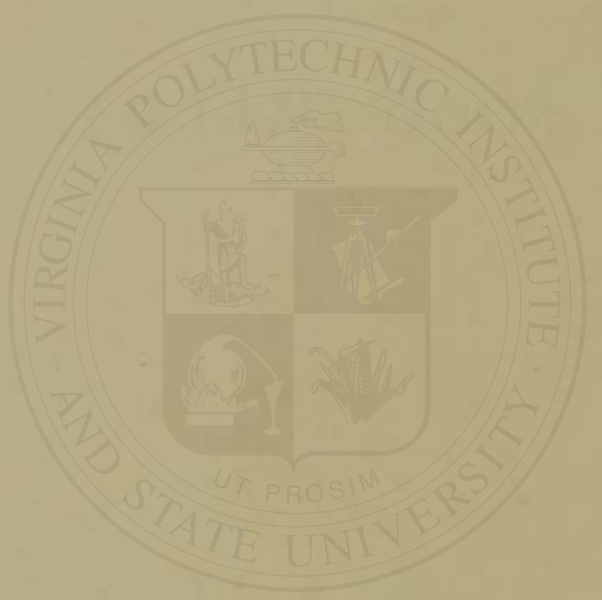




\section{FOOD VALUES}

PRACTICAL TABLES FOR USE IN PRIVATE PRACTICE AND PUBLIC INSTTITUTIONS

BY

EDWIN A. LOCKE, A.M., M.D.

INSTEUCTOR IN MEDICINE, HARVARD MEDICAL SCHOOL

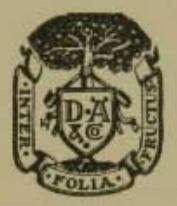

NE W Y ORK A N D LONDON

D. APPLETON AND COMPANY 1918 


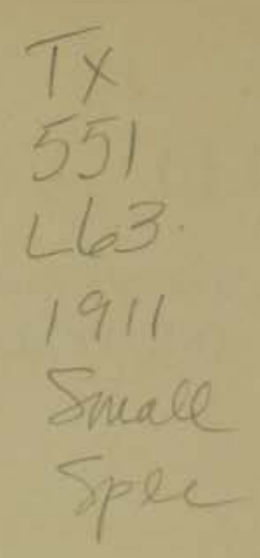

463

1911
Small
Spec

Copyntart, 1911, geY

D. APPLETON AND COMPANY

PRINTED AT THE APPLETON PRESB

NEW YORK, U. B. A.

SCANNED AT VIRGINIA POLYTECHNIC INSTITUTE AND STATE UNIVERSITY 


\section{PREFACE}

THE numerous tables of chemical analysis of foods and of food values appearing during recent years have made possible a more precise qualitative and quantitative regulation of the diet for the sick. Such tables, however, are not readily accessible, or are arranged in such form as to be applied to practical dietetics only with considerable diffieulty. The majority necessitate the actual weighing of the foods and often tedious calculations in order to determine the exact nutritive values; procedures which greatly detract from their practical usefulness. Furthermore the figures given are usually for raw food values which frequently differ considerably from those of cooked foods.

In the present volume I have attempted to bring together from various sources as exact information as possible regarding the composition and nutritive value of all common foods in a form so simple that it can be readily applied to the every day regulation of diets. The work has been prepared especially for the students in the Harvard Medical School.

It is obvious that many factors combine to make the caleulations of the nutritive worth of cooked foods exceedingly difficult and in many instances the results given must be regarded as only approximate. 


\section{PREFACE}

No original chemical analyses have been made by the author but all ealculations are based on actual weighings. It is not a treatise on dieteties and no attempt has been made to give special diets for particular diseases or conditions. In the following pages, however, some of the principles of dieteties which apply especially to the use of the tables are briefly discussed. Our knowledge of the relative digestibility of different foods is so incomplete that no discussion of the subject is given.

It has been impossible to give eredit in all eases to the authors eonsulted. Information has been drawn largely from the numerous reports of investigations made under the direction of the United States Department of Agrieulture, especially those of Atwater, Bryant, Langworthy, Grindley, Wood and Milner.

Grateful acknowledgment is made of the valuable advice and assistance given by Drs. H. F. Hewes and David L. Edsall in the preparation of these tables. 


\section{O N T E T S}

PAGE

INTRODUCTION • . . . . . . . . 1

Table I.-EQUivalents OF Weights AND Measures • . . . . . . . 25

Table II.-Prepared Foods-Edible PorTION

Table III.-Alcoholic Beverages • • • 58

Table IV.-Average Chemical Composition OF AMERICAN Foods . . . . . . 63

$\operatorname{INDEX} \cdot \cdot \cdot \cdot \cdot \cdot \cdot \cdot \cdot \cdot \cdot 101$ 


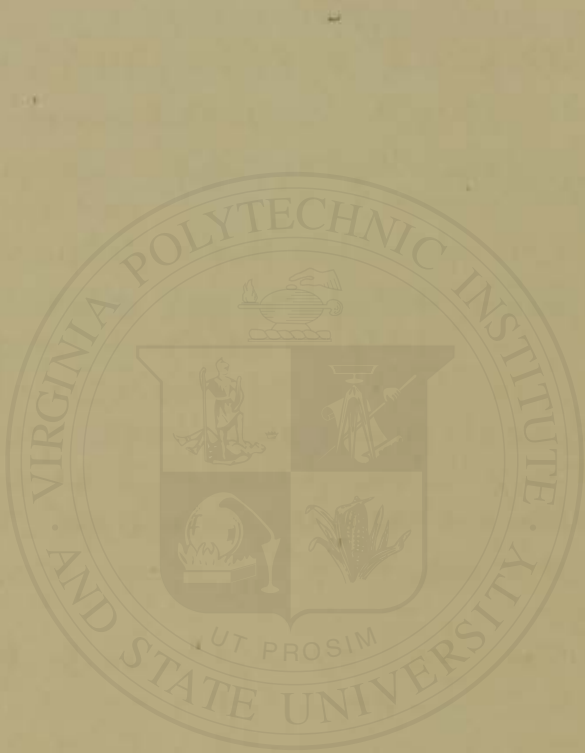




\section{FOOD VALUES}

\section{INTRODUCTION}

\section{CLASSIFICATION OF FOOD STUFFS}

THE various food materials, although frequently classified as organic or inorganie, are more reasonably divided into (1) nutritive and (2) non-nutritive constituents. The former are chiefly organic, the latter largely inorganie substances.

Atwater and others group the nutritive constituents into four general classes, i. e.: (1) protein, (2) fats, (3) carbohydrates, and (4) mineral matter or ash. The nonnutrient constituents include water, refuse (bones of meat and fish, shells of shell-fish, stones of fruit, skins of fruits and vegetables, etc.), and the salts of salted meats and fish.

In the following tables the term "edible portion" (Atwater) is used to include the nutritive portion and water, i. e., flesh of meat and fish, white and yolk of egg, pulp of fruit, ete., while the term "as purchased" indieates the total edible portion plus the refuse.

Protein.-Protein as employed by Atwater is a comprehensive term comprising all nitrogenous substances whether of animal or vegetable origin except the nitrogenous fats. As distinguished from protein the proteids are definite chemical compounds such as the albumin of meat and the white of egg which form only a portion of 
the general group of proteins. Hoppe-Seyler and Dreehsel $^{1}$ classify the protein bodies as follows: (1) Simple Proteids (albumins, globulins, nueleoalbumins, albuminates, proteoses and peptones, coagulated proteids and histones), (2) Compound Proteids (hemoglobins, glucoproteids and nueleoproteids), (3) Albumoids or Albuminoids (keratins, elastin, eollagen and reticulin).

Carbohydrates. - The earbohydrates embrace an unusually large number of compounds such as sugars, stareh, gums and cellulose, and form the principal constituent of plants as do the proteids of meats. Though found chiefly in such foods as are derived from the vegetables, nuts, fruits and grains, they are also present in small amounts in milk, meat, and fish.

Fats.-This group is made to include the total ether extract of the dried substance, and eomprises both plant and animal fat besides a variety of other substances, including neutral fat, fatty acids, lecithin, cholesterin, coloring matter, tannin, wax and ash residue. These last mentioned, however, are present in very minute traces and the heat of combustion of the total ether extract has been shown to be practically identical with that of pure fat. (Stohmann. ${ }^{2}$ )

Mineral Matter or Ash.-A considerable number of inorganic elements (chlorine, sulphur, phosphorus, sodium, ealcium, magnesium, iron, manganese, potassium and others) are contained in the food, to a small extent as organic compounds, but prineipally as salts (earbo-

${ }^{1}$ Cited by Hammarsten, "A Text-Book of Physiological Chemistry," p. 36 .

"Quoted by Schwenkenbecher, Zeit. f. diet. u. physik. Terapie, Bd. 4, 1900, s. 388. 
nates, sulphates, phosphates, oxides, ete.). They are never oxidized in the system to furnish heat or energy, but are essential in tissue building.

Water.-The importance of water in the diet of man, though a non-nutrient, is attested by the fact that nearly two-thirds of the body weight is due to water.

\section{USES OF FOODS IN THE BODY}

In general the function of food ingested is twofold, first, to build up or repair tissues, and second, through combustion to furnish energy either as heat or museular work ineluding the work of digestion. The degree to which the various food ingredients discussed above answers in these respects to the body needs is various. Protein foods, like lean meat and fish, egg albumen, easein of milk, wheat gluten, and the proteid portion of vegetables, are essentially the tissue builders but under some conditions, especially when the amount of fats and earbohydrates is insuffieient, are utilized by the organism to provide energy. It is probable also that proteids may be ehanged to fat. The fats, both animal and vegetable, and the earbohydrates, very largely furnish the energy required. To a considerable extent the fats of the food may be stored up as body fat but only when the ingested food is more than adequate to meet the demands of the body for tissue building and energy. Likewise when taken in excess the earbohydrates may be transformed into fat and stored as adipose tissue. Neither ean go to the building up of tissue yet they act as proteid sparers and indirectly serve this purpose.

It will thus be readily seen that the functions of the 
three kinds of nutrients in the body are to a certain extent interchangeable, and the purpose which each serves will depend largely on the quantity of the other two. In other words the degree to which the three types of food stuff's participate in the production of energy will depend on their relative proportion in the diet as much as on any preference on the part of the organism.

This fact is of the greatest importance in the regulation of the diet in certain diseases. Thus if we aim to increase the body weight in a given ease it is as important to provide adequate amounts of fats and earbohydrates in order to spare the proteids which would otherwise to some degree be used to answer the needs for heat and energy, as to increase the nitrogenous foods.

As stated above, mineral matter does not contribute to the energy needs of the body yet is absolutely essential in the food, first, beeause it forms bone and other tissues, and second, because of its influence on general metabolism. It is generally agreed that, with the exception of sodium chloride, the average mixed diet comprises more than a sufficient quantity of mineral matter to supply the body needs.

It has been shown experimentally beyond a doubt, that alcohol in small quantities, like the fats and carbohydrates, is entirely oxidized in the body and the energy thus produced is utilized by the body largely as heat but also to some degree as muscular work. Alcohol must in consequence be considered with the foods. It differs from other foods in not being stored in the body as fat for future use. To some extent, at least, it undoubtedly acts in a manner analogous to the earbohydrates and fats in sparing the protein. The maximum action of this sort 
probably takes place in those habitually addicted to its use. There is considerable experimental evidence to indicate that alcohol likewise spares the carbohydrates and even the fats. Under no conditions can it serve to repair or build tissue. Unlike other foods, alcohol, when taken into the body in large amounts, not only acts as a food but as a drug also. This action often outweighs its effects as a nutrient. Any food may, when taken in excess, act deleteriously, but these effects in the case of alcohol are proportionately greater beeause of its action as a drug. ${ }^{1}$

\section{METHODS OF CALCULATING FOOD VALUES}

All foods possess potential or latent energy which with combustion becomes kinetic or actual. This holds true whether it is burned in a ealorimeter or oxidized in the body. When oxidized in the body this energy appears both as heat and museular power. Atwater has shown by calorimeter experiments that when the body is in a state of eomplete rest all the energy is represented by heat and the work of metabolism, whereas with activity a considerable portion appears as museular work. In either ease the total "exactly equals the latent energy of the material burned in the body." This energy of foods is known as the heat or fuel value and is expressed in terms of a heat unit or ealorie. A calorie is the amount of heat necessary to raise one kilogram of water from $0^{\circ}$ to $1^{\circ} \mathrm{C}$. or 1 pound $4^{\circ} \mathrm{F}$. This is sometimes spoken of as

${ }^{1}$ For a full discussion of the action and nutritive value of alcohol, see Atwater, "Physiological Aspects of the Liquor Problem," vol. ii., 1903. 
the "large calorie," the "small ealorie"' being 1/1000 of a large calorie, or the amount of heat necessary to raise one gram of water from $0^{\circ}$ to $1^{\circ} \mathrm{C}$. Stohmann ${ }^{1}$ gives the following heat values for protein, fat and earbohydrate, when completely burned in the calorimeter:

1 gram protein . ..... 5,711 small calories... 5.7 large calories.

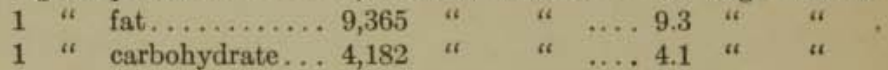

Digestibility. - If completely oxidized and transformed in the body the same figures would hold for these ingredients; but as is well known not all the food is utilized in the body, the unused portion appearing in the exereta. In order therefore to obtain the exact heat value of a given food when ingested, it is necessary to know not only its ealorimeter value, but also the energy value of that portion which has escaped oxidation and appears in the feees and urine, the difference obviously being the so-called " available fuel value." Consequently it becomes of the first importance to determine what proportion of the food taken into the body is digested and absorbed, in other words, is available for body needs. This is designated as the "coefficient of digestibility." (Atwater.) It may be defined as the total energy value of a given food less that of the unoxidized exereta.

The digestibility of nutrients differs slightly when given in a mixed diet from that of the same when ingested separately. Atwater's figures of digestibility ?

1" Ueber den Wärmewerth der Bestantheile der Nahrungsmittel." Zeit. f. Biologie, Bd. 31.

"The term digestibility is used by Atwater to indicate the completeness of digestion, and not the ease of digestion as ordinarily employed. 
for the average mixed diet are : protein 92 per cent, fats 95 per cent, and earbohydrates 97 per cent, those of animal origin being considerably higher than those of vegetable. Of the total food in a mixed diet 91 per cent is estimated to be entirely digested and transformed into energy. The coefficient of digestibility of alcohol is 98 .

Availability.-A further consideration of very great moment in the ealculation of food values is the completeness with which the available protein, fat and earbohydrate are burned in the body. Since the fats, earbohydrates and alcohol are almost completely oxidized, their available energy is represented by eonstants which are very close to those for the same oxidized outside the body. Not only is there a considerable loss in the amount of proteid available for oxidation, as stated above, namely 8 per cent, but a considerable portion of the remainder escapes complete oxidation and appears in the form of the nitrogenous excreta in the urine (urea, ete.) Whereas the coefficient of digestibility of protein is 92 , the coefficient of availability of energy is only 70 . (Atwater.) The nltimate energy value developed by change and oxidation of foods in the organism is termed the "physiological heat of combustion."

From his own investigation and those of many others, Rubner ${ }^{1}$ ealculates this physiological ealorie value as follows:

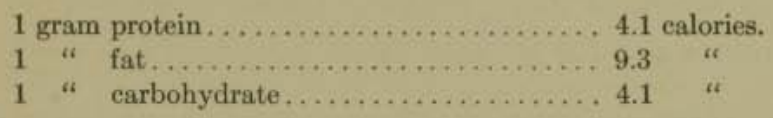

1 "Calorimetrische Untersuchungen." Zeit. f. Biologie, N.F., Bd. $3,1885$. 
The physiological ealorie value of alcohol is 7. More recently Atwater and Bryant ${ }^{1}$ have revised these figures basing their conelusions on a large number of eareful investigations. A summary of their results is given in the following table : ${ }^{2}$

\begin{tabular}{|c|c|c|c|c|c|c|c|}
\hline & \multirow{3}{*}{$\begin{array}{c}\text { Heat of } \\
\text { com- } \\
\text { bustion } \\
\text { per } \\
\text { gram. }\end{array}$} & \multicolumn{2}{|c|}{$\begin{array}{l}\text { Coefficients of } \\
\text { svailability. }\end{array}$} & \multicolumn{4}{|c|}{ Fuel values. } \\
\hline & & \multirow{2}{*}{$\begin{array}{l}\text { Of ma- } \\
\text { terial. }\end{array}$} & \multirow{2}{*}{$\begin{array}{c}\text { Of } \\
\text { energy. }\end{array}$} & \multicolumn{2}{|c|}{$\begin{array}{l}\text { Referred to avail- } \\
\text { able material. }\end{array}$} & \multicolumn{2}{|c|}{$\begin{array}{l}\text { Referred to tota } \\
\text { material. }\end{array}$} \\
\hline & & & & Per grm. & Perlb. & Per grm. & Per lb. \\
\hline & Cal. & $\begin{array}{c}\text { Per } \\
\text { cent. }\end{array}$ & $\begin{array}{l}\text { Per } \\
\text { cent. }\end{array}$ & Cal. & Cal. & Cal. & Cal. \\
\hline Protein. & 5.65 & 92 & 70 & 4.4 & 2,000 & 4.0 & 1,815 \\
\hline Fat. & 9.40 & 95 & 95 & 9.4 & 4,260 & 8.9 & 4,040 \\
\hline Carbohydrates & 4.10 & 97 & 97 & 4.1 & 1,860 & 4.0 & 1,818 \\
\hline Aleohol...... & 7.07 & 98 & 98 & 7.1 & 3,210 & 6.9 & 3,130 \\
\hline
\end{tabular}

It will be seen that Atwater's figures eorresponding to those of Rubner given above are:

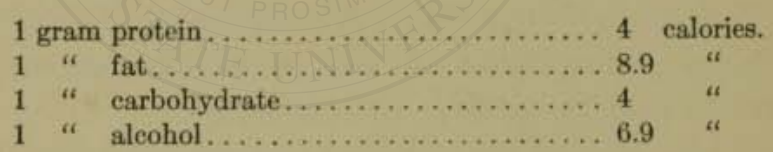

While more accurate than Rubner's figures, the latter have attained such general aeceptance that practically all tables of food values available are based on these values and for the sake of uniformity it has seemed best

1 "The Availability and Fuel Value of Food Materials." Report of the Storrs (Connecticut) Agricultural Station, 1889.

" "Physiological Aspects of the Liquor Problem," vol. ii., p. 281. 
to use the same in the preparation of the following tables.

\section{THE FOOD REQUIREMENTS OF THE BODY IN HEALTH}

In spite of numerous eareful researches no precise general rules ean be laid down regarding the food requirements which shall apply to all persons. The needs of the organism for nutriment both with relation to its kind and quality must depend on many factors. First of all it is evident that these needs bear a direct relationship to the size of the body, large individuals requiring more food than smaller ones. The average man in health and with moderate work is found to require roughly 40 calories per kilogram of weight. The extent of body surface likewise determines to some degree the amount of fuel needed inasmuch as the radiation of heat is relatively greater in those with proportionately large skin surface. The thinner the individual, the greater the relative skin surface and hence the greater the demands for food. A partial explanation is found here for the fact that thin people frequently eonsume more food than the obese. Added reasons for this difference are found in the sedentary habits of life so often characteristic of the obese, and in the lessened metabolism. Fat tissue as well as bone is virtually dead tissue when compared with muscle since it participates but little in the general processes of waste and repair. Whereas the average man at work requires somewhere between 30 and 60 calories per kilogram of weight to maintain health and strength, the very fat have been observed to preserve 
their weight and vigor on from 26 to 36 ealories per kilo of weight.

Children have relatively more skin surface than adults, and the ealls for food are correspondingly inereased. Young cells furthermore oxidize a greater quantity of food. Still another important reason is that the young organism needs food for the growth of new tissue as well.

An exactly opposite condition exists in the aged. There is lessened body activity, a diminished vitality in the body cells, and commonly a smaller degree of heat radiation. In consequence the food consumption is deereased beyond the period of maximum vigor and in extreme old age surprisingly little is required to meet the demands of the organism. The young infant utilizes nearly 100 calories per kilogram, the aged searcely more than one-quarter to one-third as much.

It is estimated that on the average women take barely four-fifths as much food as men, due largely to the smaller size, the greater percentage of body fat, and the less active life.

Climate and seasons exert some influence, though by reason of the methods of dress among civilized people, which protects the body from excessive loss of heat by radiation, far less than would at first be supposed. To some extent the demands of the system in cold climates increase the fuel needs of the body.

Marked individnal differenees in the amount of food digested and assimilated, apart from such differences as are due to size, age, mode of life, shape of body, and similar factors, are commonly observed. Not only is this individual variation seen with reference to the amount 
of food required, but also in the proportions of the different ingredients. In both health and disease, one likewise frequently sees that a particular kind of food does not agree with a given individual. These individual peculiarities are important considerations in the regulation of the diet, especially in conditions of ill-health.

The one factor of probably more importance than all the above combined is muscular work. Langworthy ${ }^{1}$ summarizes the results of statistical and experimental studies with regard to the food requirements of man under varying conditions of work as follows:

Man without muscular work . . . . . .

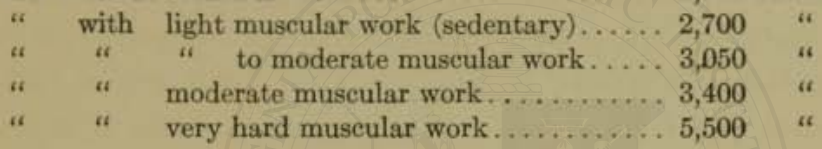

In the case of Maine lumbermen working during the winter months the food consumed in a single day in some instances was found to be capable of yielding over 8,000 calories. It seems to be generally agreed that a man at moderately hard work requires somewhat more than 3,000 ealories daily.

Atwater has shown by calorimeter experiments that in the case of the man performing work, as contrasted with the man at rest, only about 20 per cent of the additional food taken appears as the energy equivalent of work, that is, for every 20 ealories developed and applied as work, 80 ealories are lost in the body as heat and "internal work."

${ }^{1}$ United States Department of Agriculture, Office of Experiment Station, Circular No. 46, 1906. 
While it is fairly generally conceded that the average man at work requires approximately 3,000 ealories daily, there is a wide divergence of opinion as to the relative amounts of the protein, earbohydrates and fats best suited to furnish these needs. Unfortunately physiologieal experiments are frequently not in accord with the results of actual studies of the diet taken by individuals of different races and under varying conditions. While the question cannot at present be finally settled, the proportions of nutrients taken by the average person is probably the safest guard. These figures are, roughly, 150 grams fat, 100 grams protein, and 350 grams earbohydrates per diem.

The most important question is as to the quantity of protein best suited to the needs of the average individual. In spite of very numerous experiments by many eminent physiologists as well as eareful studies regarding the amount consumed by various races and classes, it still remains an open question. The work of Chittenden and others proves that health may be maintained under the ordinary conditions of life for a long period on a daily ingestion of proteids even as low as 50 grams daily. It has not been shown, however, that such a low proteid content is an advantage or if continued indefinitely may not work injuriously. A large excess of protein taken with a diet rich in fats and earbohydrates, especially with hard muscular work, is, as a rule, well tolerated, observations having been made frequently where more than 200 grams of protein were taken daily and well tolerated. Without an ample supply of fats and earbohydrates, however, an excess of protein leads to severe digestive disturbances and must be regarded as 
distinetly harmful. The form in which the protein is ingested is also important. At least one-half should be in the form of vegetable protein except in the case of persons doing very severe work when a larger proportion of animal protein may be allowed.

Granting that 100 grams of protein is a fair average for a diet yielding 3,000 ealories, the proportion of the fats and earbohydrates best suited to the body needs is the next consideration. The ratio of these two ingredients in the diet of different individuals varies within very wide limits as shown by many dietary studies. Although energy derived from the carbohydrates seems to spare the proteids to a slightly greater degree than that from the fats, they may for all practical purposes be considered of equal importance as proteid sparers. The vital question appears to be not as to the ratio of the two, but rather that the necessary caloric value of the diet be maintained. When additional food is required because of hard museular work there is good reason for the opinion that the supplementary calories should be supplied largely by earbohydrates and fats.

The influence of mental work on the fuel needs of the body has not been so accurately determined as in the ease of museular work. One important fact, however, has been established by the calorimeter experiments of Atwater, ${ }^{1}$ namely that the body waste is not increased by brain activity. There seems to be no evidence for supposing that any particular kind of food is indicated in the ease of brain workers, or that the ealorific needs are greatly or even to any extent increased. Overeating

1 United States Department of Agriculture, Office of Experiment Station, Bulletin No. 44, 1897. 
is detrimental to hard brain work for the reason that under such conditions excessive work is put on the digestive organs necessitating an abundant blood supply to the abdominal organs which undoubtedly interferes to a eonsiderable extent with the supply needed by the brain. Intellectual workers are usually of sedentary habits and require much less food in general and a smaller pereentage of fats and earbohydrates than those doing manual labor. In a word, the food required by this elass is relatively small and should be of such a nature as to put as little burden as possible on the digestive organs.

\section{THE BODY'S RESERVE}

It is one of nature's provisions that the body should to a considerable though varying degree act as a storehouse of fuel. On a sufficient diet the body stores up in the form of fat tissue a greater or smaller reserve which during a period of insufficient food or actual starvation ean for a remarkably long period sustain life. At first only adipose tissue is oxidized, but later even the nitrogenous tissues may also be utilized. Death usually oceurs after the reduction of from one-third to one-half the body weight. Underfeeding, especially an insuffieiency of nitrogenous foods, inevitably leads to a lessening of body resistance, and finally, to physical deterioration as evideneed by abundant examples too familiar to be enumerated.

Continued overfeeding, if extreme, brings in time a chain of evil eonsequences of nearly equal importance. The proper diet is probably one moderately in excess of that absolutely necessary to answer the demands of the body for tissue repair and energy as it is desirable to 
have a reserve of fuel in the body. One of the first results of excessive food ingestion in many cases, though by no means all, is an abnormal inerease in the body weight due to the accumulation of adipose tissue. The principal ill effects are those consequent on the relatively great amount of additional work thus put on the system in disposing of the extra fuel. If for only a short time, the effects are seldom more severe than moderate disturbances in the functions of the gastro-intestinal tract. In the case of habitual overalimentation, grave disorders of metabolism or even degenerative changes take place in the body tissues especially in the internal organs and arteries.

"For people in good health and with good digestion there are two important rules to be observed in the regulation of the diet. The first is to choose the things whieh 'agree' with them, and to avoid those which they cannot digest and assimilate without harm. The second is to use such kinds and amounts of food as will supply all the nutrients the body needs and at the same time avoid burdening it with superfluous material to be disposed of at the cost of health and strength.

"For guidance in this selection, nature provides us with instinet, taste and experience. Physiological chemistry adds to these the knowledge-still new and far from adequate - of the composition of food and the laws of nutrition. In our actual practice of eating we are apt to be influenced too much by taste-that is, by the dictates of the palate; we are prone to let natural instinet be overruled by acquired appetite, and we negleet the teachings of experience. We need to observe our diet and its effects more carefully and to regulate appetite by reason. In doing this we may be greatly aided by the 
- knowledge of what our food contains and how it serves its purpose in nutrition." (Atwater.)

\section{COOKING OF FOODS}

The nutritive value of foods is very definitely influenced by cooking. As a rule they are made more digestible for the reason that their structure is so altered as to render them much more easily chewed and more acessible to the digestive juices. Their eomposition is also often considerably changed, depending on the method of cooking. During this process certain flavors are developed which give them a more pleasing taste and so directly assist digestion through stimulation of the digestive functions. Bacteria and parasites are killed by most forms of eooking.

The above applies especially to the cooking of meats, although by some methods they suffer a very signifieant loss in nutrients. Meats lose weight in cooking largely in consequence of the loss of water, and to a variable extent of fat.

The following table compiled from Schwenkenbecher ${ }^{1}$ illustrates in a general way these losses in weight:

\begin{tabular}{|c|c|c|c|}
\hline 100 grams raw, lean meat. & $\begin{array}{l}\text { Boiled. } \\
\text { Grams. }\end{array}$ & $\begin{array}{c}\text { Rare, } \\
\text { Grams. }\end{array}$ & $\begin{array}{c}\text { Well done. } \\
\text { Grams. }\end{array}$ \\
\hline 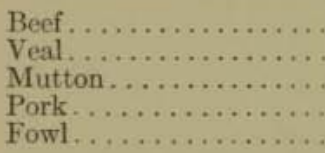 & $\begin{array}{l}58 \\
72 \\
65 \\
63 \\
70\end{array}$ & $\begin{array}{l}82 \\
78 \\
85 \\
78 \\
76\end{array}$ & $\begin{array}{l}62 \\
61 \\
70 \\
57 \\
\cdots\end{array}$ \\
\hline
\end{tabular}

1 "Die Nährwerthberechnung tischfertiger Speisen." Zeit. $f$. diāt. u. physik. Therapie, Bd. 4, H. 5, 1900. 
The changes taking place in meats as the result of cooking have been made the subject of very careful experimental studies by Grindley and Mojonnier ${ }^{1}$ and their conclusions are briefly as follows: When meats are boiled from 3.3 to 12.6 per eent of the protein, 0.6 to 37 per cent of the fat, and 20 to 67 per cent of the salts were found in the broth. When roasted, 0.3 to 4.6 per cent of protein, 4.5 to 57.5 per cent of the fat and 2.5 to 57.2 per eent of the mineral matter were found in the drippings of the meat. If the broth in the former and the drippings in the latter be used there is obviously only an insignificant diminution in food value. To a certain extent the losses vary directly with the length of time of cooking and inversely with the size of the piece of meat. Different euts of the same kind of meat vary greatly in the amount and nature of the losses. Sehwenkenbecher concludes from the study of the results of numerous investigations that 100 grams of the muscle portion of the common meats when boiled yields roughly from 160 to 180 calories, when roasted, rare, about 130 calories, well done, 150 to 230 calories. The edible portion of lean fish boiled furnishes approximately $80-100$ calories per 100 grams. Piekling and smoking alters but very slightly either the composition or nutritive value of meat and fish. On the whole the meats are rendered more palatable by eooking but slightly less digestible and sometimes less rich in nutrients.

In vegetables as in the case of meats the flavors are

1 "Experiment on Losses in Cooking Meat," United States Department of Agriculture, Office of Experiment Station, Bulletin No. 141. 
produced, the structures altered, and the proteids coagulated. The most important changes are in the starch granules, the cell walls of which are ruptured and the starch made more soluble. While a proper degree of cooking renders the vegetables more palatable and digestible, excessive cooking produces changes in them which make the vegetables unpalatable and indigestible.

Snyder, Frisby and Bryant, ${ }^{1}$ investigated the effects of boiling on the composition of vegetables using potatoes, earrots and cabbage as representatives of the three groups, tubers, roots, and pot herbs. They found a considerable though variable loss in mutritive constituents depending on the methods employed. In the ease of the potatoes, the greatest loss took place when they were peeled and then soaked in cold water before boiling, namely 46 to 58 per cent of the nitrogenous matter and 38 per cent of the mineral matter. When put immediately into boiling water, the loss in mineral matter remained the same but the loss in nitrogenous matter was only one half as great. If boiled unpeeled, the losses were insignificant. As ordinarily eooked earrots were found to lose about 40 per eent of the total nitrogen and 26 per cent of the total sugar, or approximately one quarter of the nutritive value. Cabbage when boiled in lime water lost about one-half of the mineral matter and one-third of the carbohydrates and nitrogenous matter.

1 "Losses in Boiling Vegetables and the Composition and Digestibility of Potatoes and Eggs," United States Department of Agriculture, Office of Experiment Stations, Bulletin No. 43 . 
This loss ean be largely prevented if the water in which the eabbage is cooked be used.

\section{METHOD OF CALCULATING FOOD VALUES}

In the ordinary tables of food analysis such as those of Atwater and Bryant, the chemical composition of foods is given in percentages by weight of protein, fats and carbohydrates, and the total ealoric value per pound. It is therefore evident that in order to determine the value of a given diet each article of food must be separately weighed and the weight of the three food ingredients calculated from the table of percentages. For example, Atwater's table gives the composition of homemade white bread as 9.1 per cent protein, 1.6 per cent fat and 53.3 per cent earbohydrates. Now if one slice of bread weighs 37 grams, the actual weight of the protein, fat and earbohydrates is $3.37,0.59$ and 19.72 respectively. The number of ealories represented in each is then ascertained by multiplying the first and third figures by 4.1 , and the second by 9.3 (in each case by the number of calories per gram) which gives for protein 13.8, for fats 5.5 , and for carbohydrates 80.9 ealories, or a total of 100.2 ealories.

I have attempted to simplify the ealculations of diet by arranging a table of American foods on the basis of the "average helping." To this end the common measure of the serving is given as well as the actual weight in grams. It is believed that in this manner the value of the diet ean be estimated not only very easily but with suffieient aecuracy for all practical purposes. The actual weight of the protein, fats and carbohydrates in the 
average helping is also given, and the fuel value in calories for each. The student is thus enabled to make direct comparisons of different artieles of food according to the calories represented by each ingredient as well as the total number of ealories. The ealeulation of the total fats, earbohydrates and proteids taken at a single meal or during the twenty-four hours is made very easy.

When food is ingested in amounts other than the average helping its value ean be reckoned from its weight and the values for 100 grams given in the last column. ${ }^{1}$ Frequently in such eases the quantity eaten is a definite fraction of the "average helping" given in the table and its value ean be more readily obtained by dividing all the values given by that fraction. For example, if 1 heaping tablespoonful of apple sauce instead of 3 heaping tablespoonsful, as given in the table, be served, the value can be determined by dividing all the values in the different columms by three.

Suppose it is desired to figure the value of a given meal composed as follows : chicken soup, $4 \mathrm{oz}$; lean roast beef, 1 slice; boiled potato, 1 medium sized; string beans, 2 heaping tablespoonsful; white bread, 1 slice; butter, 1 small ball; glass milk; chocolate pudding, 2 heaping tablespoonsful, with whipped eream, 1 heaping tablespoon. Reference to Table II gives the following:

${ }^{1}$ A very convenient table scale for weighing foods is manufactured by John Chatillon \& Sons, New York. 


\begin{tabular}{|c|c|c|c|c|c|c|c|}
\hline \multirow{2}{*}{ FooD. } & \multicolumn{2}{|c|}{ Protein. } & \multicolumn{2}{|c|}{ Fats. } & \multicolumn{2}{|c|}{$\begin{array}{c}\text { Carbo- } \\
\text { hydrates. }\end{array}$} & \multirow{2}{*}{$\begin{array}{l}\text { Total } \\
\text { Cal. }\end{array}$} \\
\hline & Grams & $\mathrm{Cal}$. & Grams & Cal. & Grams & Cal. & \\
\hline Soup. & 12.60 & 51.7 & 0.96 & 8.9 & 2.88 & 11.8 & 72 \\
\hline Roast beef. & 23.33 & 95.7 & 1.66 & 15.4 & & & 111 \\
\hline Boiled potato & 3.75 & 15.4 & .15 & 1.4. & 31.35 & 128.5 & 145 \\
\hline String beans. & .48 & 2.0 & .66 & 6.1 & 1.14 & 4,7 & 13 \\
\hline White bread. & 3.37 & 13.8 & .59 & 5.5 & 19.72 & 80.9 & 100 \\
\hline Butter...... & .15 & .6 & 12.75 & 118.6 & & & 119 \\
\hline Milk. & 7.26 & 29.8 & 8.80 & 81.8 & 11.00 & 45.1 & 157 \\
\hline Chocolate pudding. ... . . & 4.99 & 20.5 & 7.90 & 73.5 & 27.83 & 114.1 & 208 \\
\hline Whipped cream.... & 1.11 & 4.6 & 7.72 & 71.8 & 1.06 & 4.3 & 81 \\
\hline Totals. & 57,04 & 234,1 & 41.19 & 383.0 & 94.98 & 389.4 & 1,006 \\
\hline
\end{tabular}

The table shows that we have a total of 57.04 grams protein, 41.19 grams fat, and 94.98 grams earbohydrates yielding respectively $234.1,383.0$ and 389.4 ealories or a total of 1,006 ealories. When only the total fuel value is desired it will readily be seen to be a very simple matter of addition to ascertain the desired figures.

On the other hand, the arrangement of weights and values in Table II facilitates the choice of a menu for special diseases as diabetes or nephritis.

The use of Table I affords a ready means of changing from one system of weights or measures to another. This is often necessary in food determinations.

Table IV is abstracted from Atwater and Bryant ${ }^{1}$ for the purpose of furnishing the percentage composition of the more common American foods for those wishing to know the exact value of raw food.

1 "The Chemical Composition of American Food Materials," United States Department of Agriculture, Office of Experiment Station, Bulletin No. 28, 1906. 


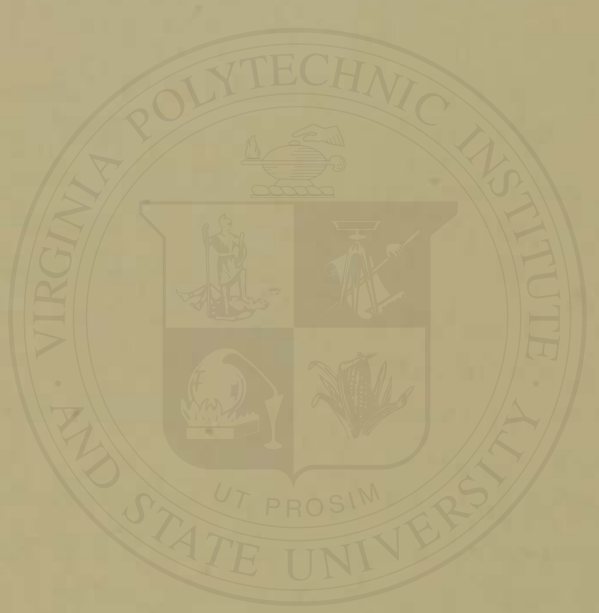




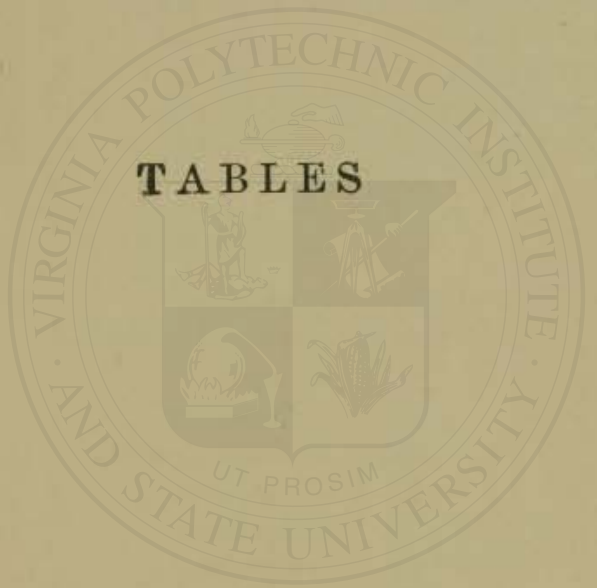


TABLE EQUTVALENTS (approximate)

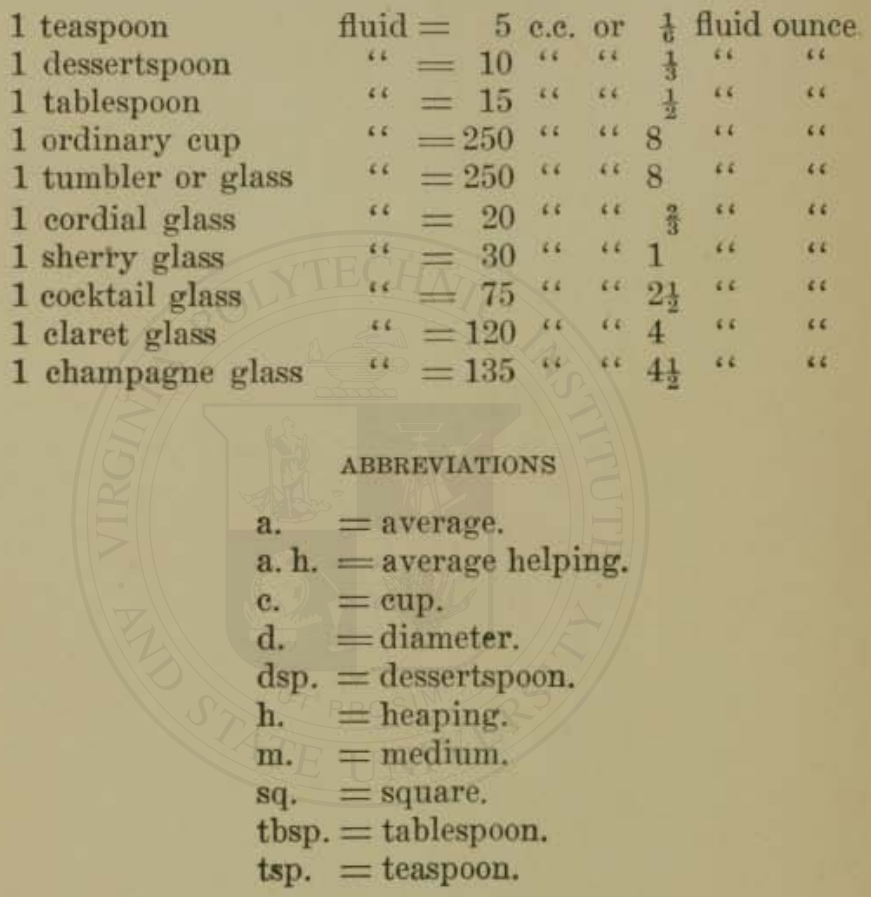




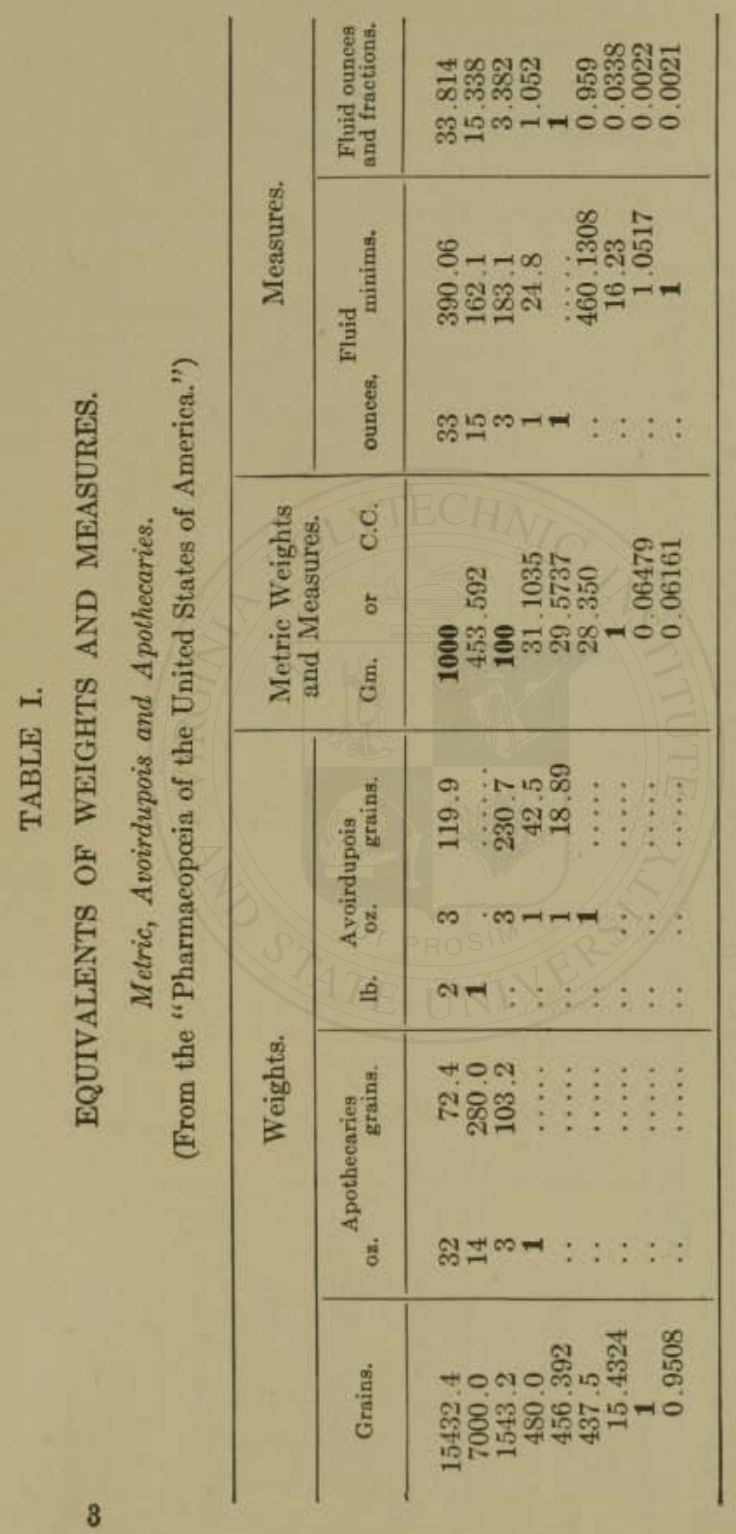




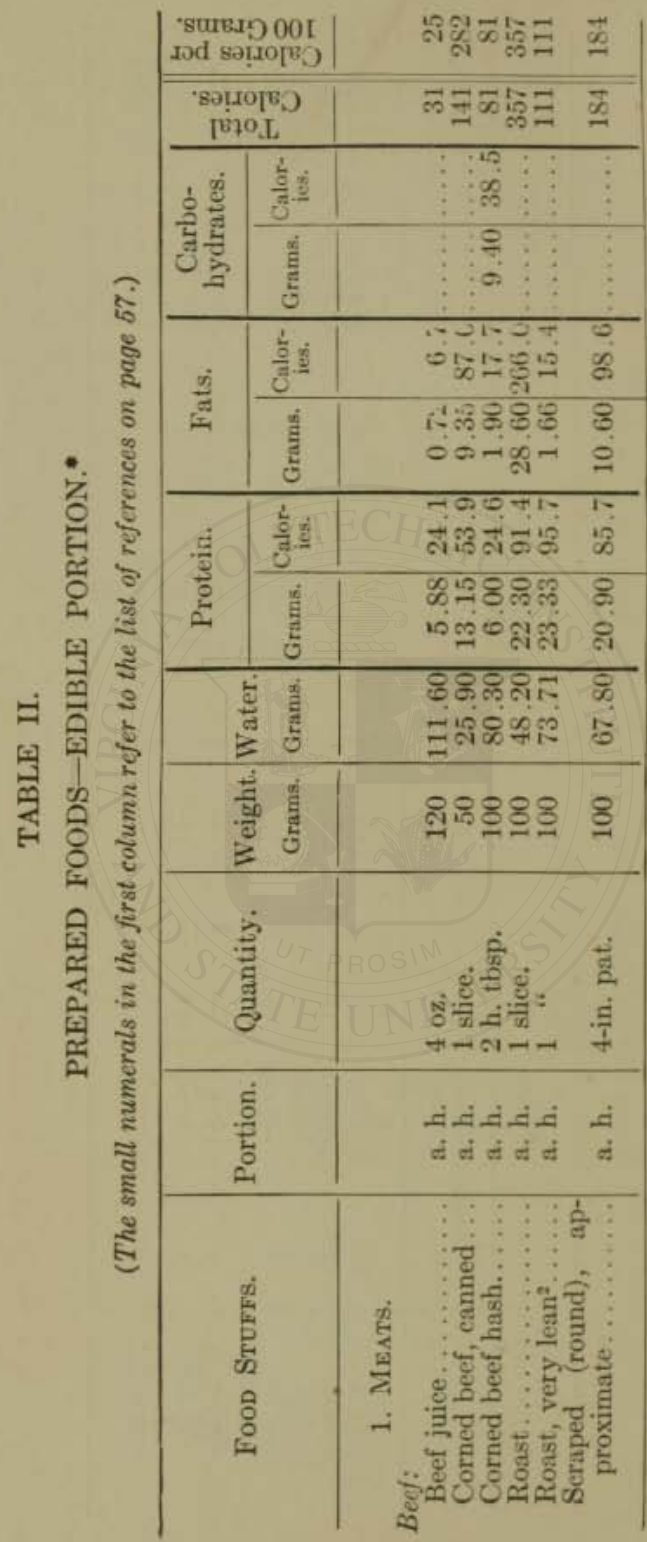

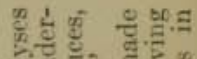

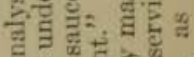

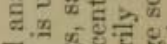
를.

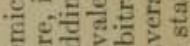

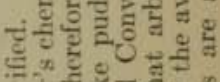

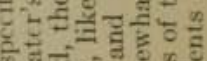

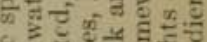

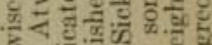
ह ह

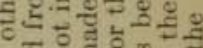
क

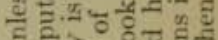
E. - 5 . 2. $=$ कू हैं H. 5.

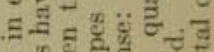
5

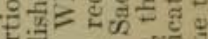
के कृ

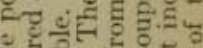
글 농

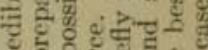

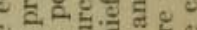
§ ․․욜

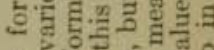

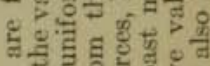

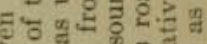
क्ष $m$ 르 퐁 대

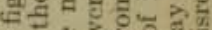

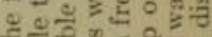

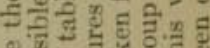
궁

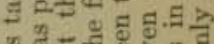

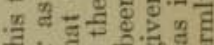

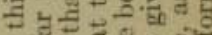
s.

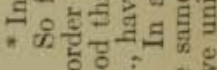

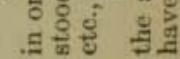


PREPARED FOODS-EDIBLE PORTION 27

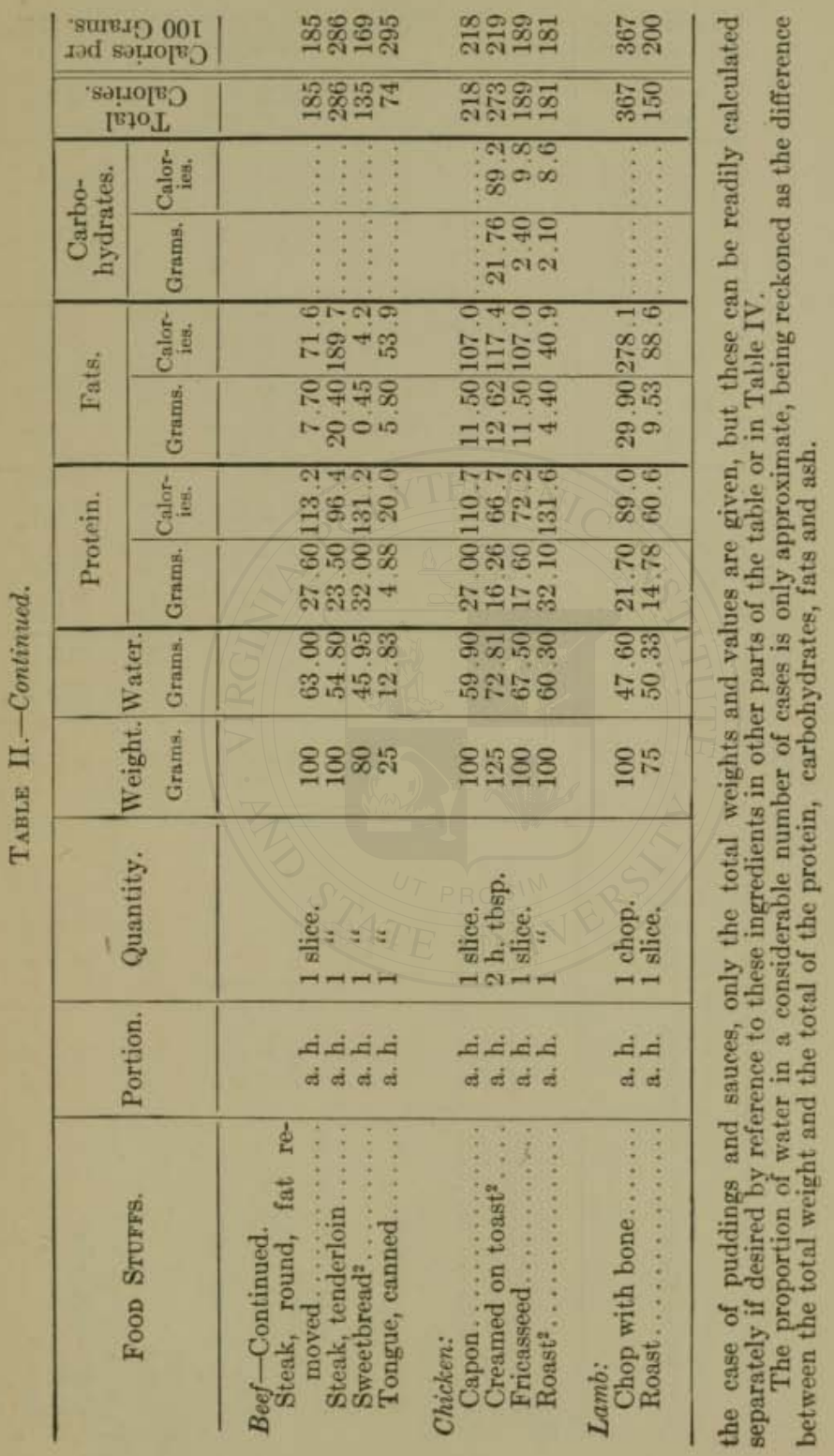




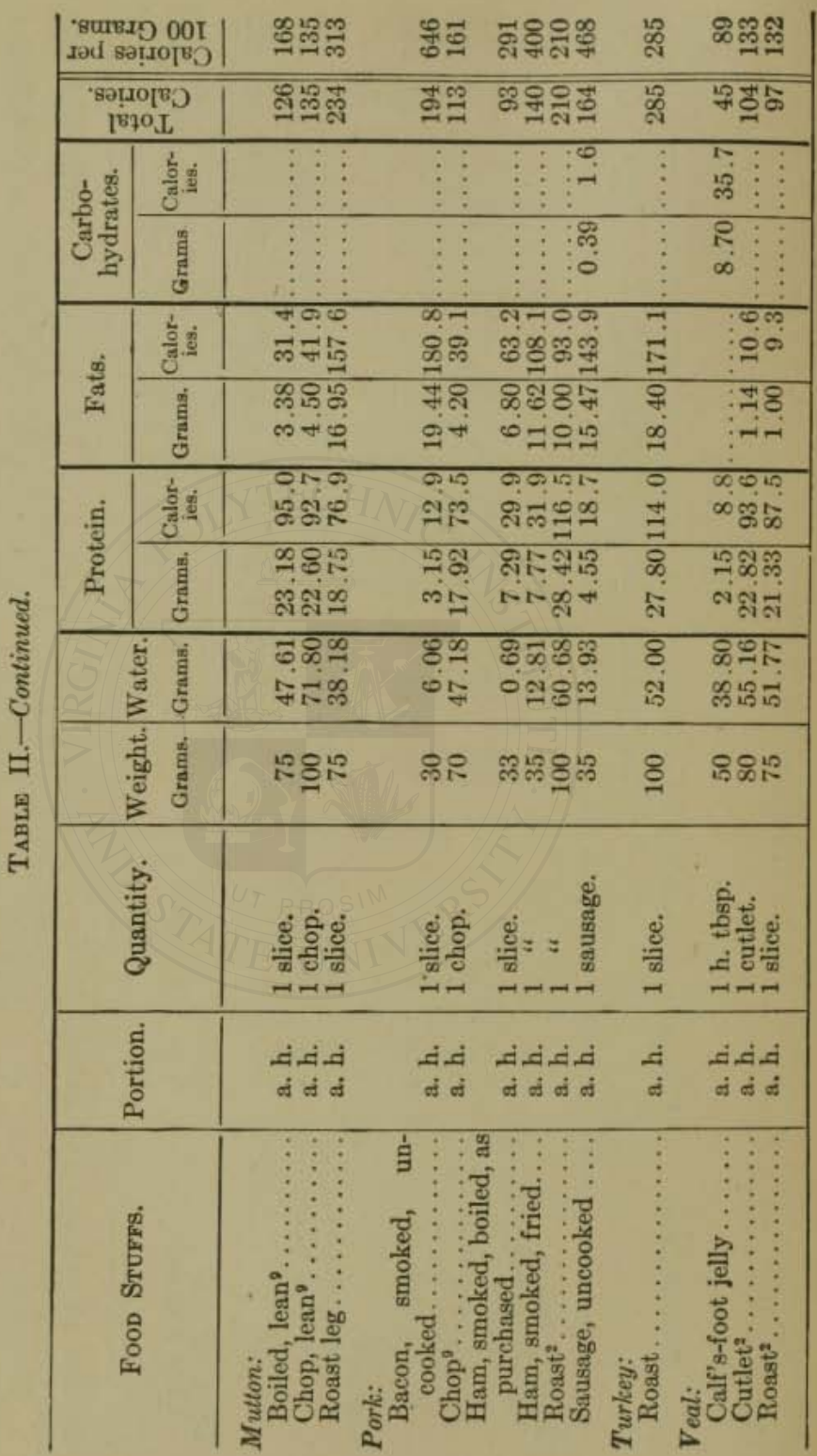




\section{PREPARED FOODS-EDIBLE PORTION 29}

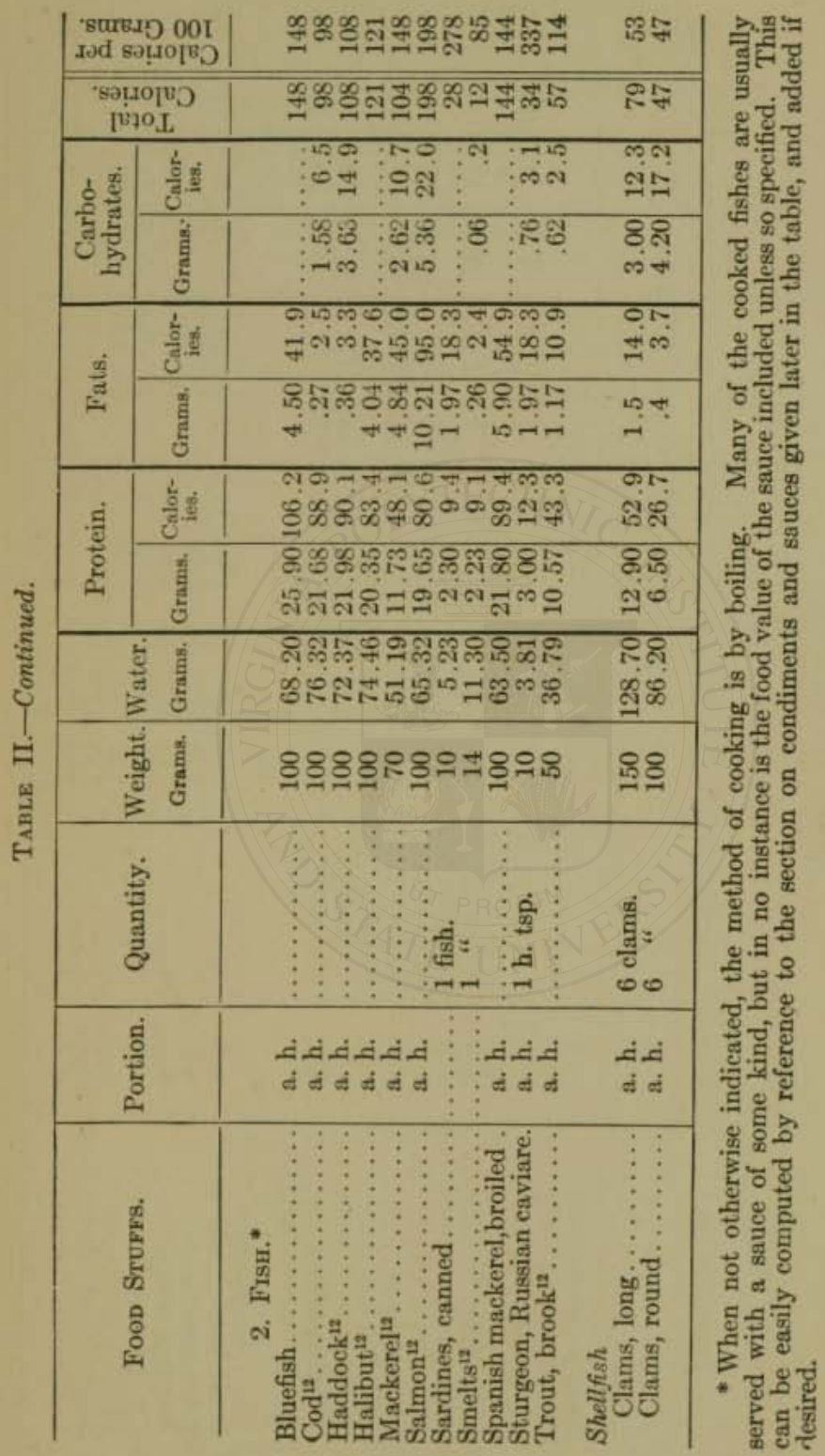




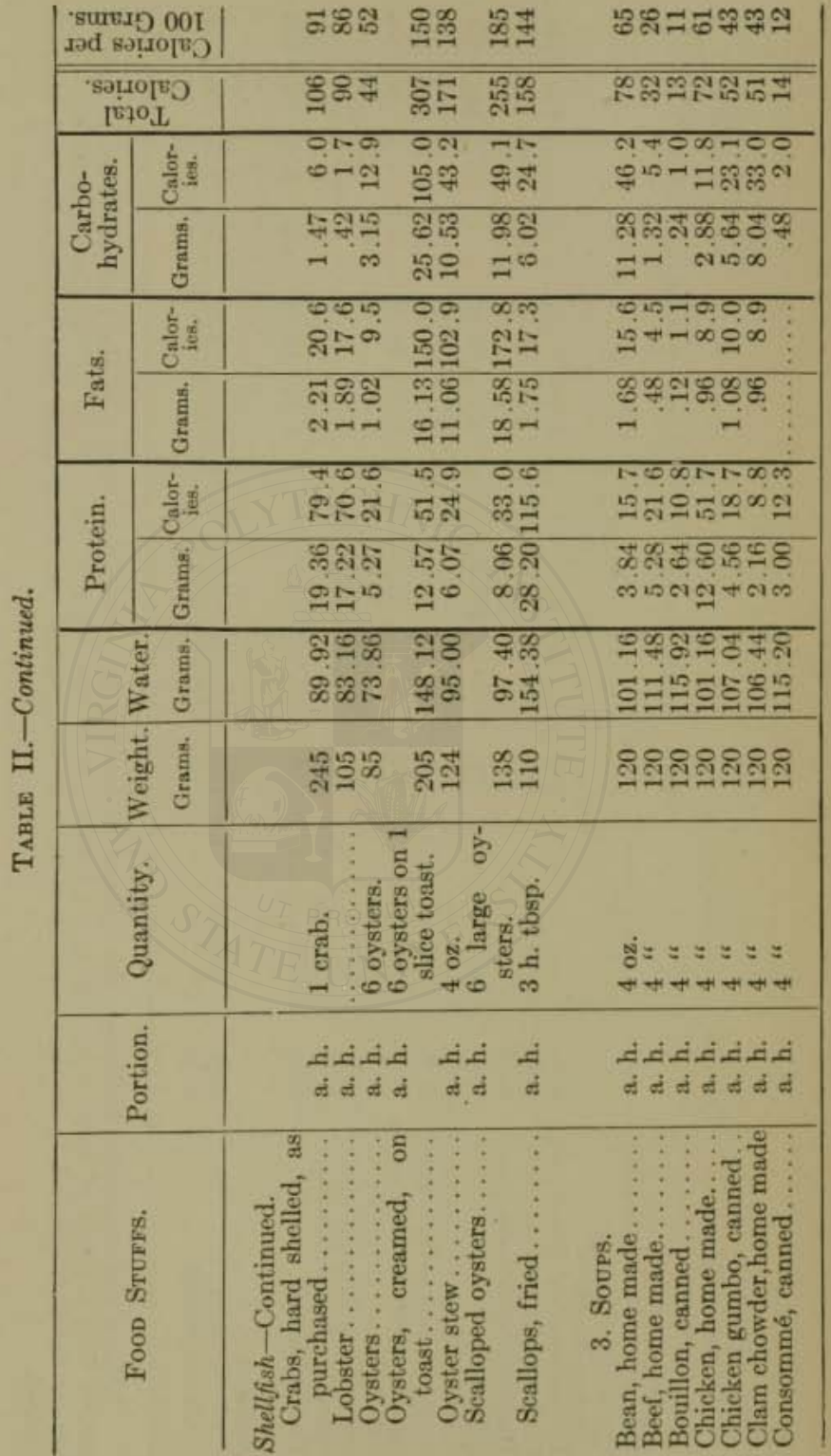




\section{PREPARED FOODS-EDIBLE PORTION 31}

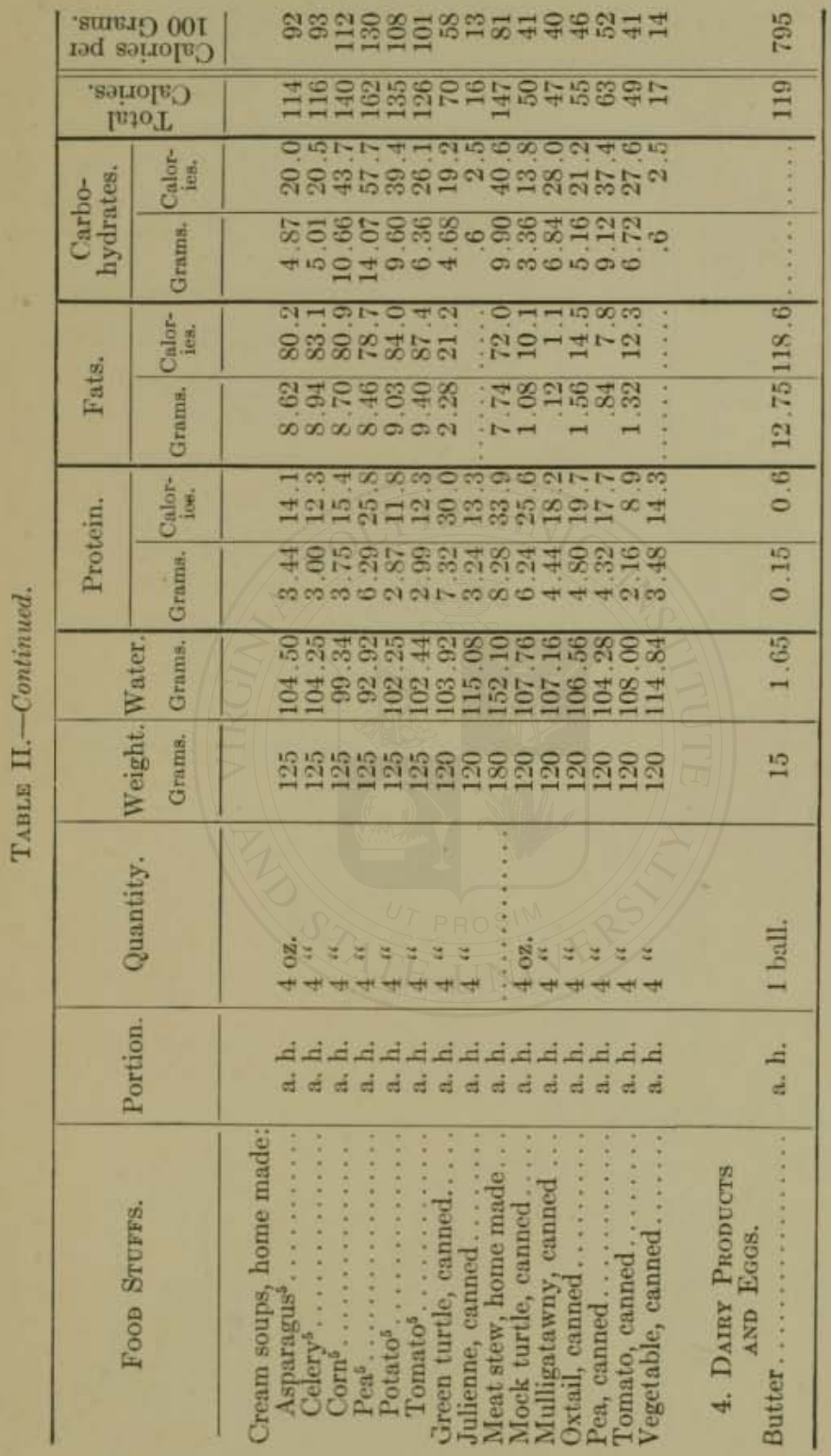




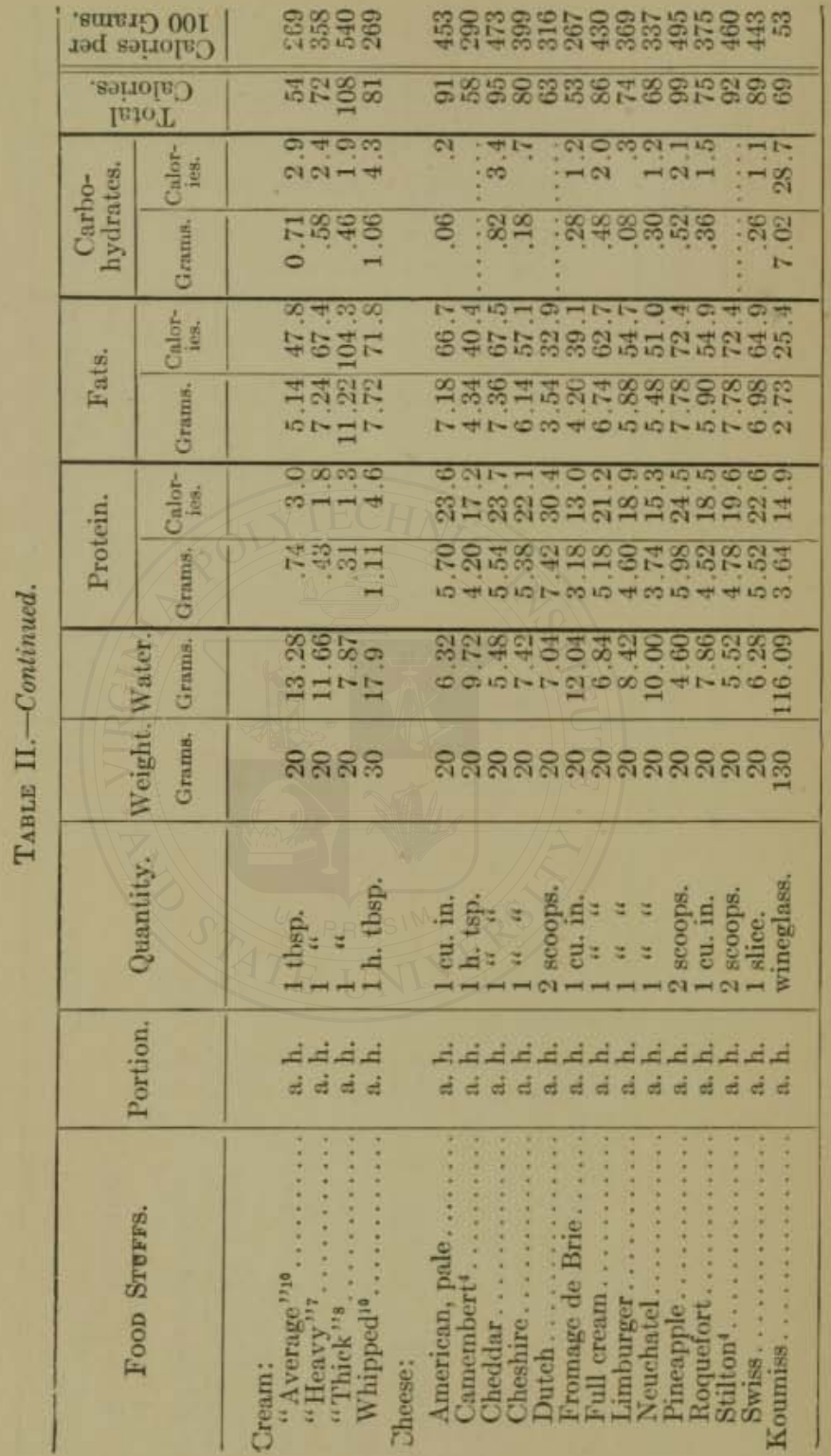


PREPARED FOODS-EDIBLE PORTION 33

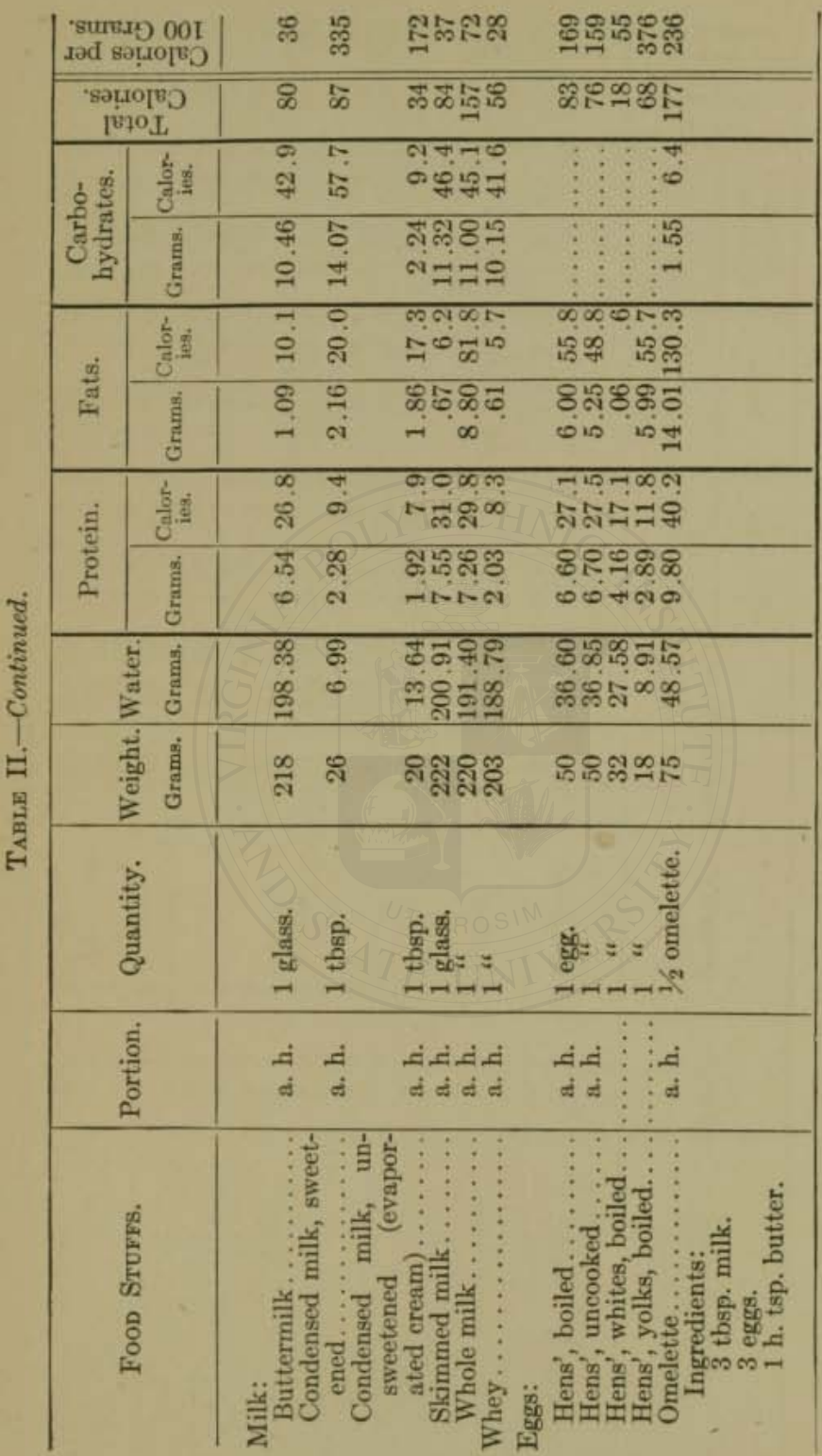




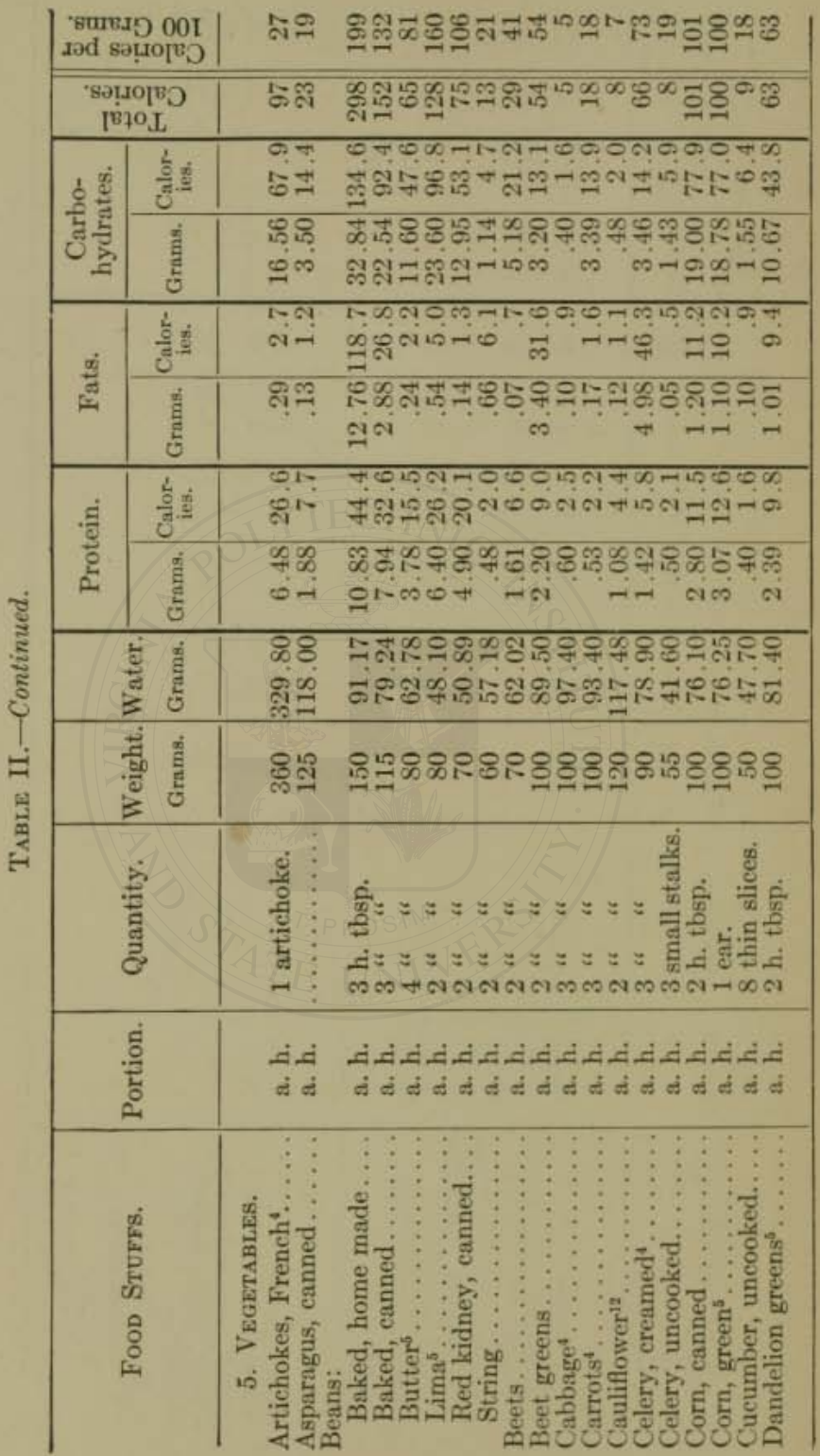




\section{PREPARED FOODS-EDIBLE PORTION 35}

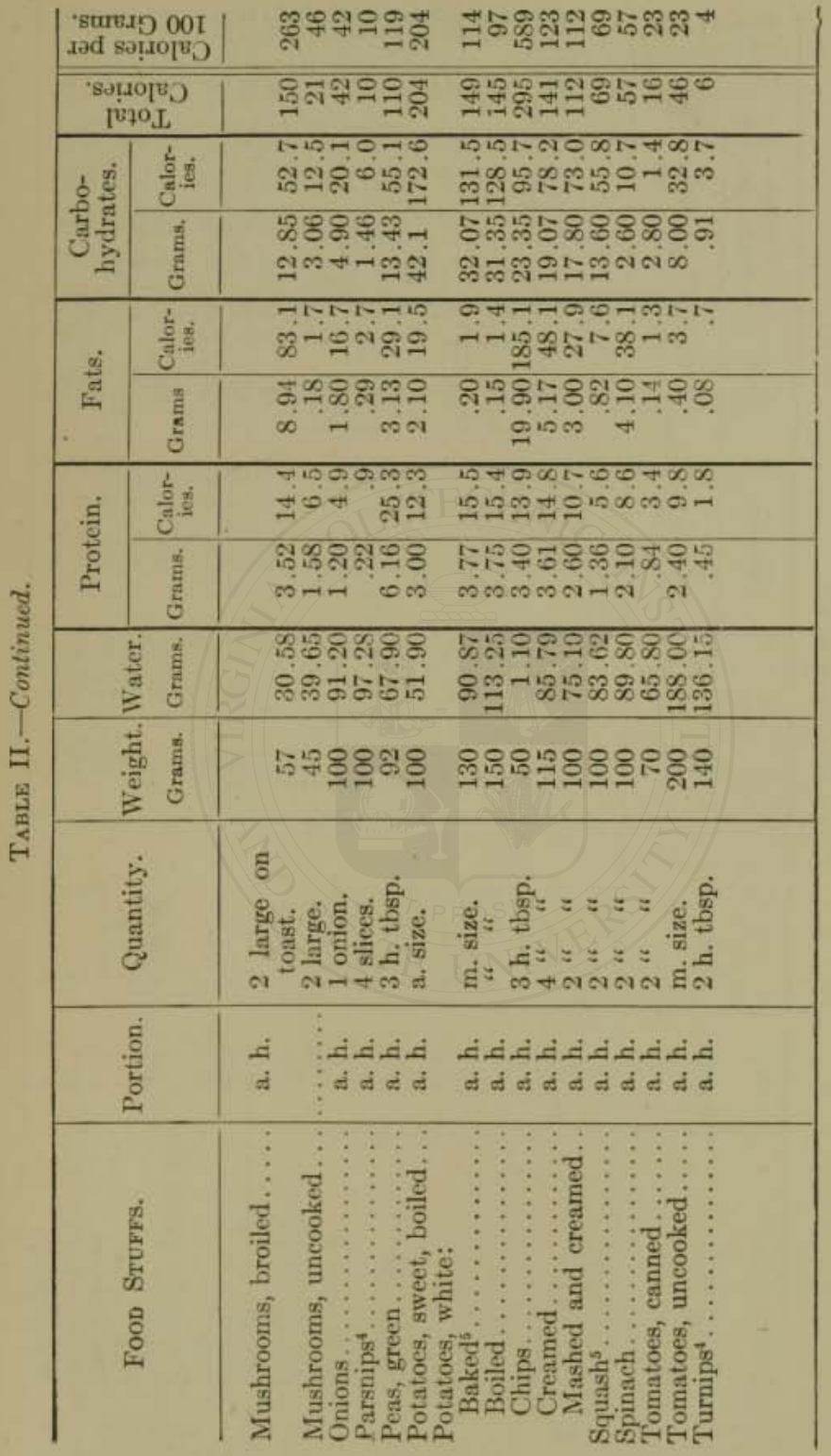




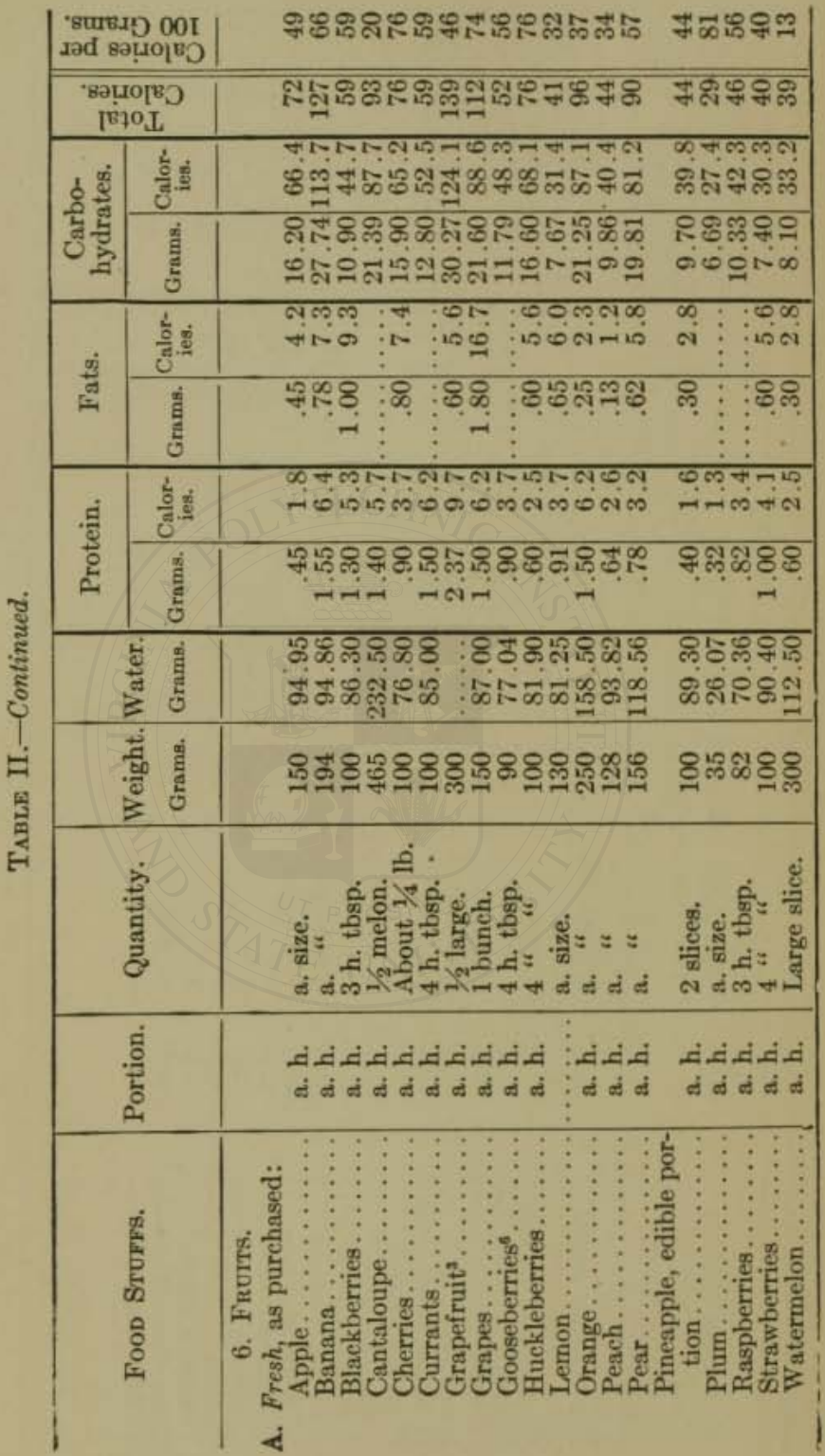


PREPARED FOODS-EDIBLE PORTION 37

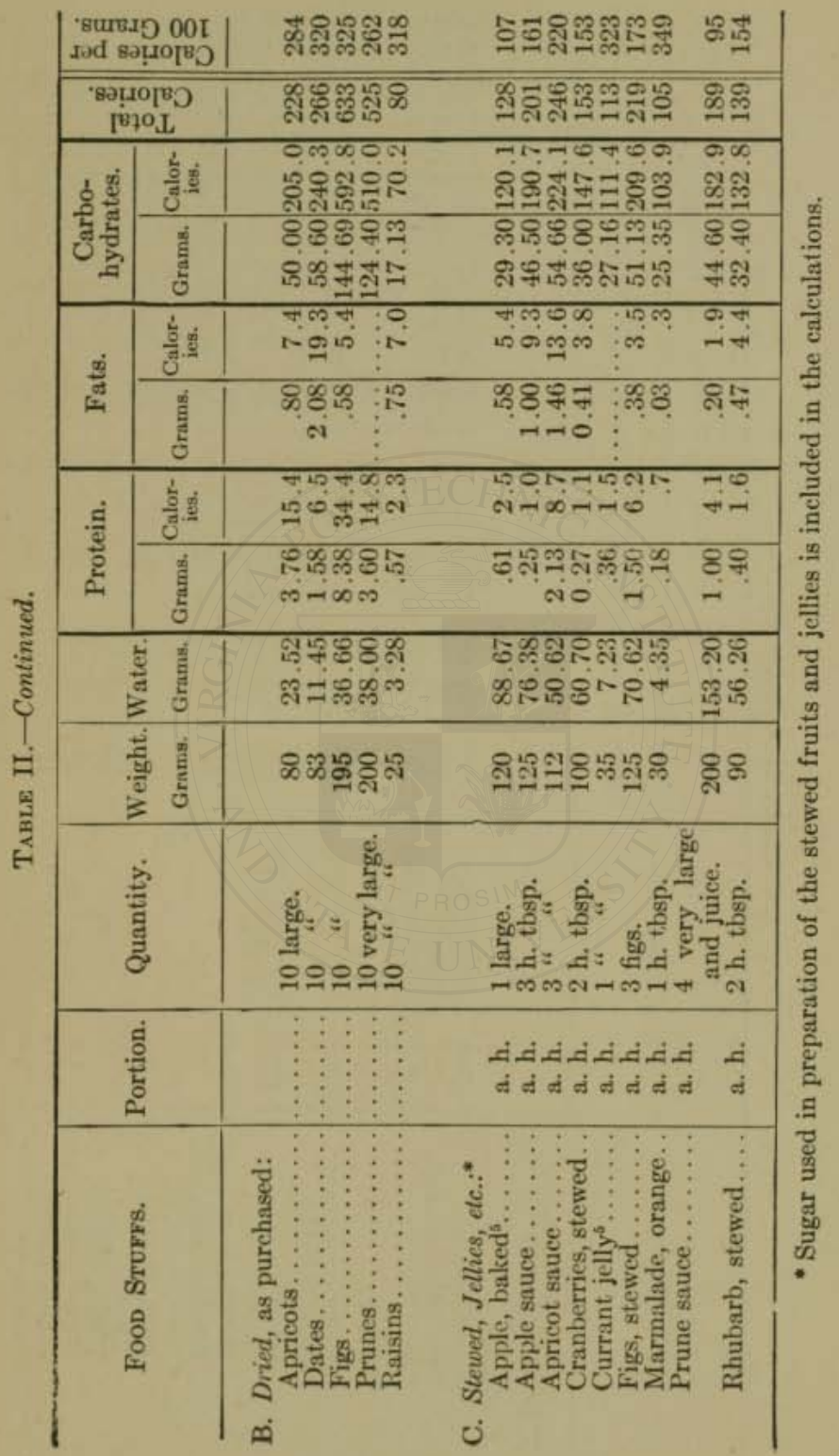




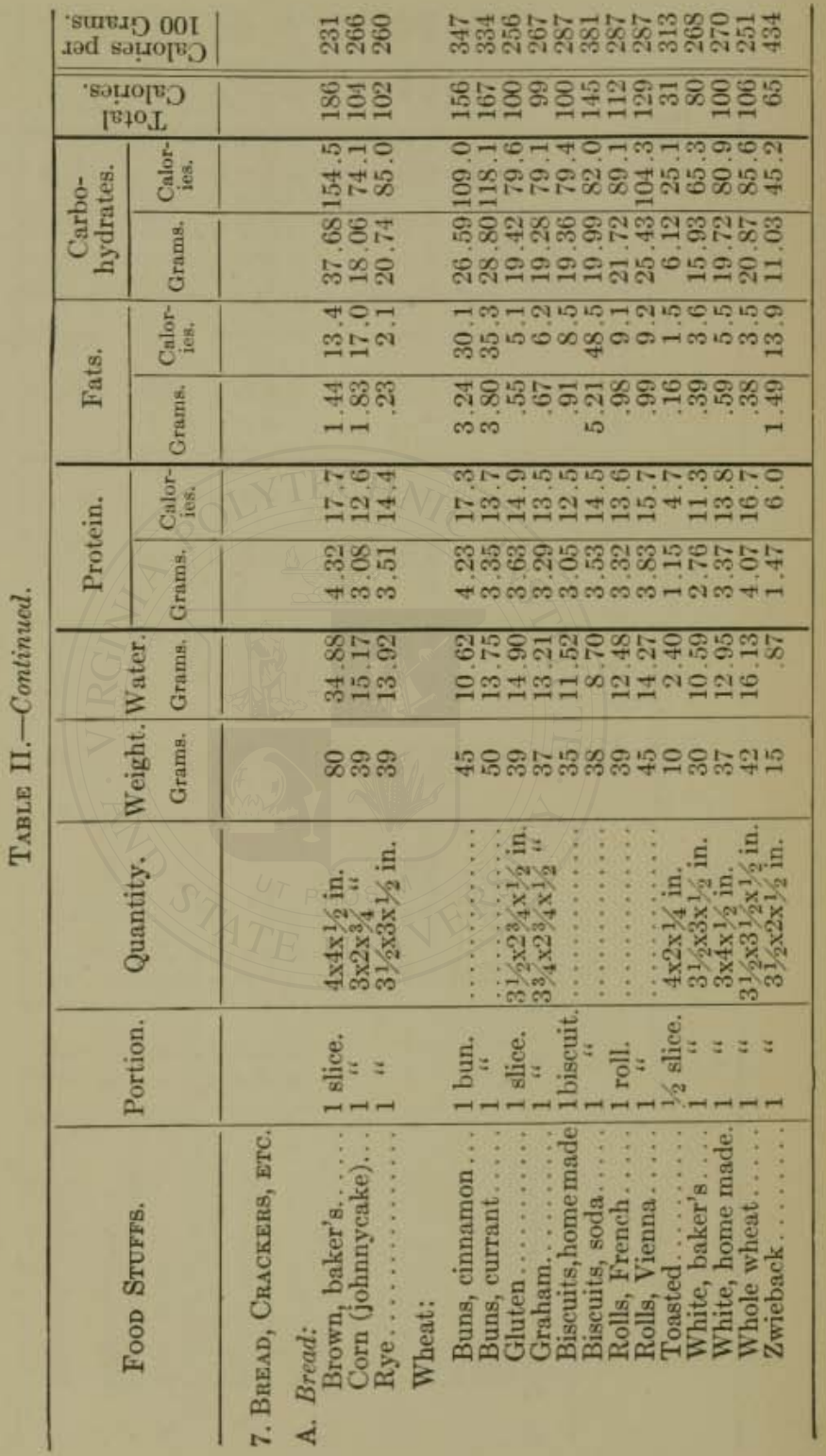




\section{PREPARED FOODS-EDIBLE PORTION 39}

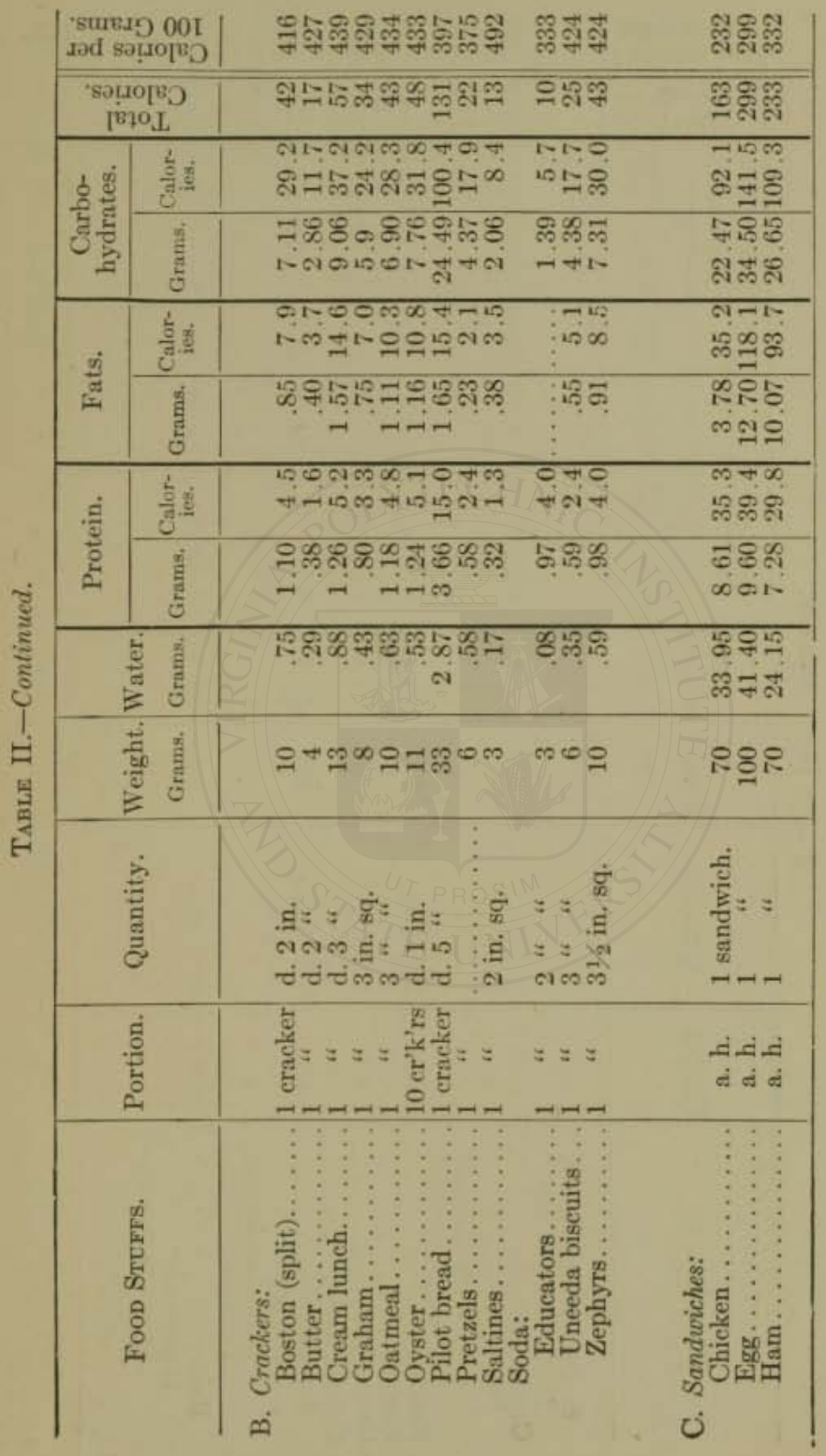




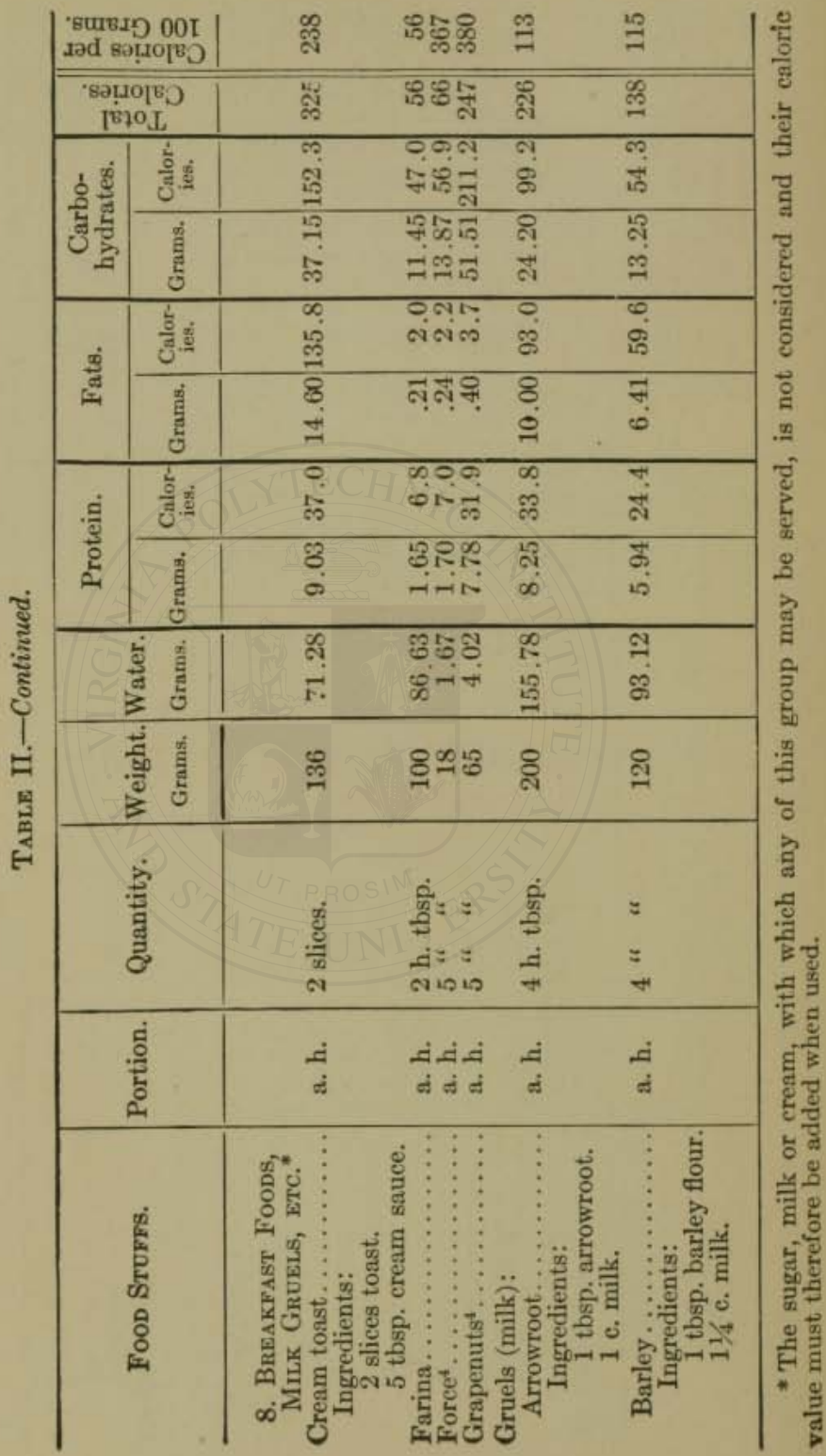


PREPARED FOODS-EDIBLE PORTION 41

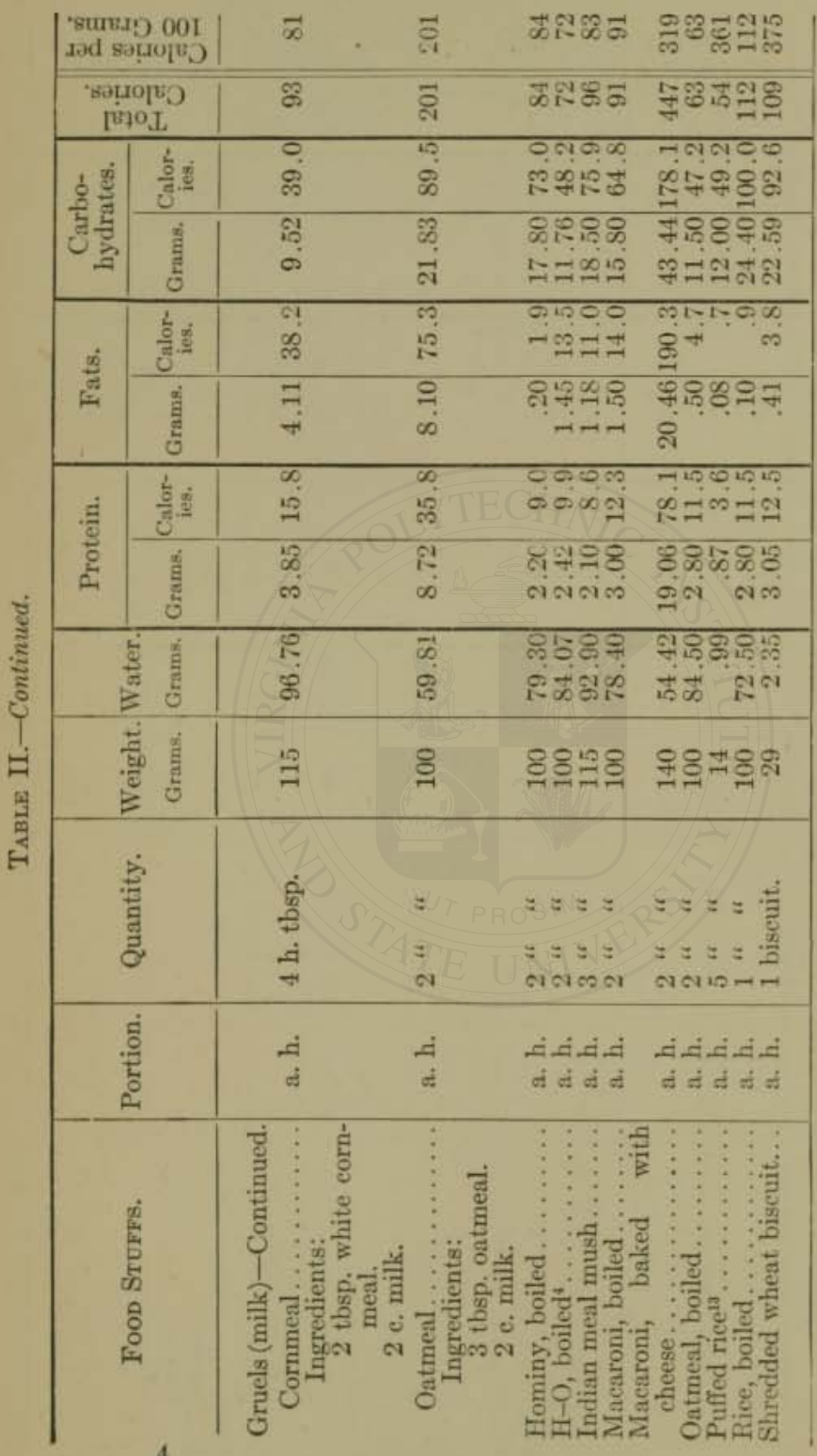




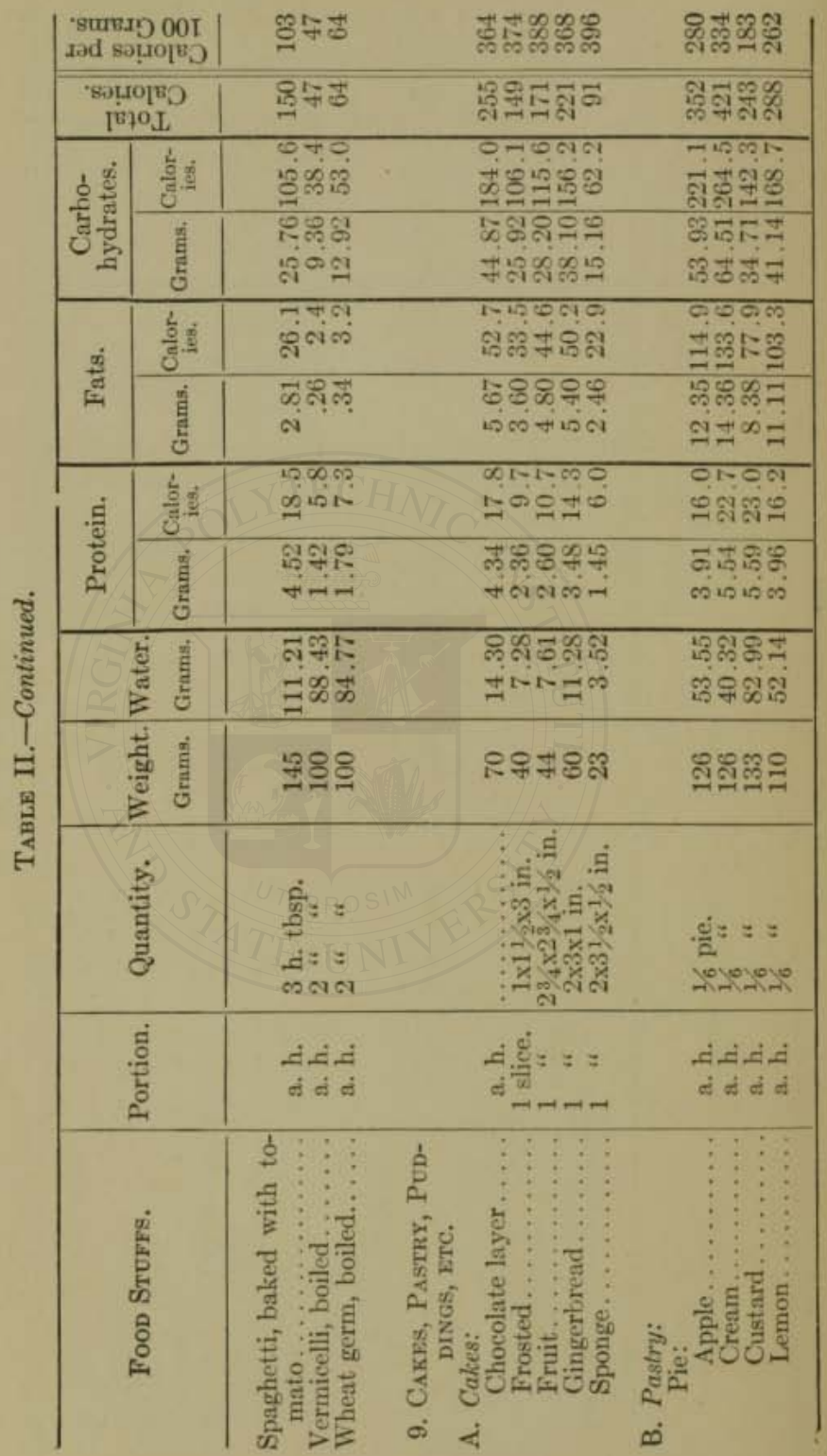




\section{PREPARED FOODS-EDIBLE PORTION 43}

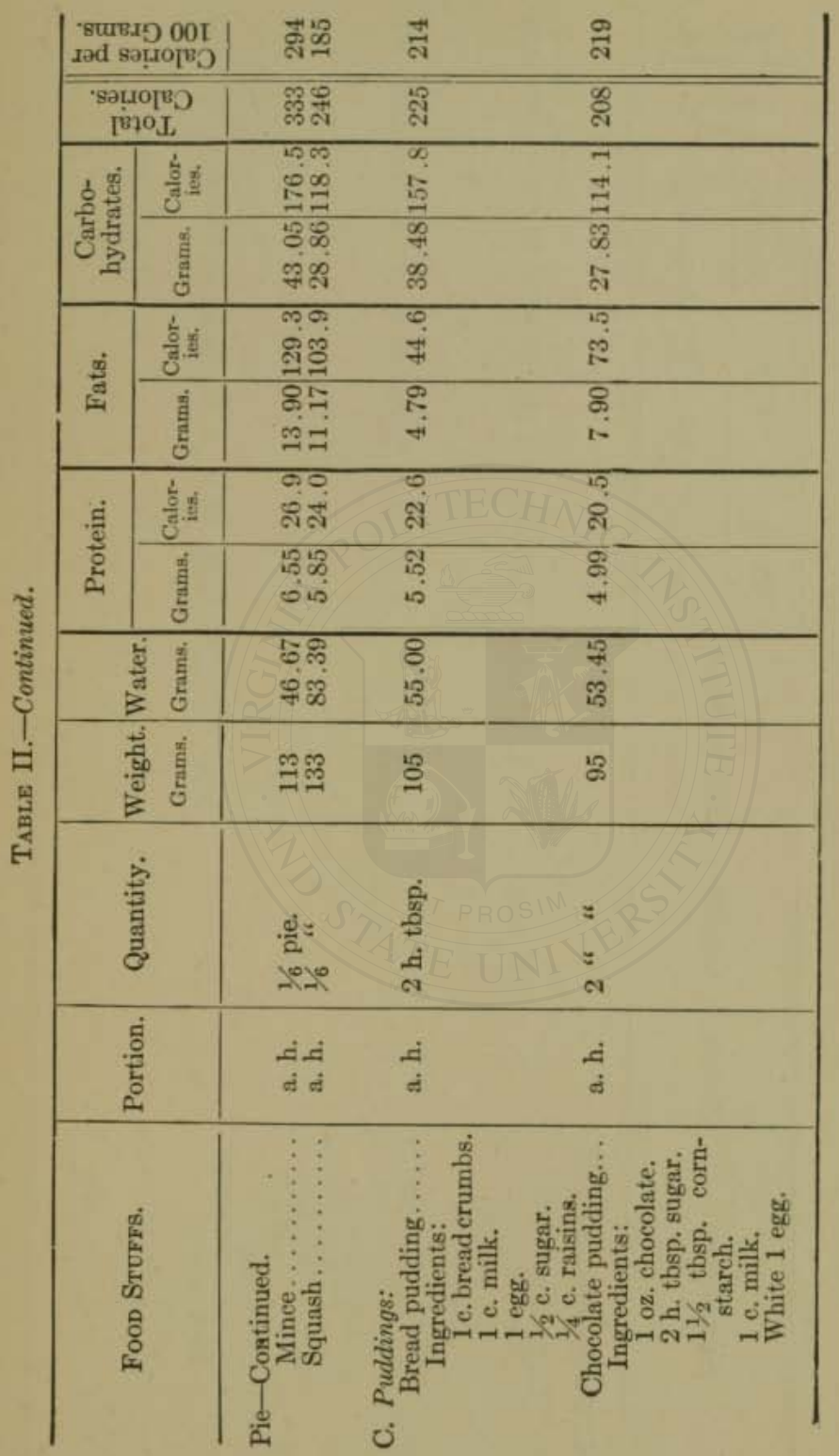


FOOD VALUES

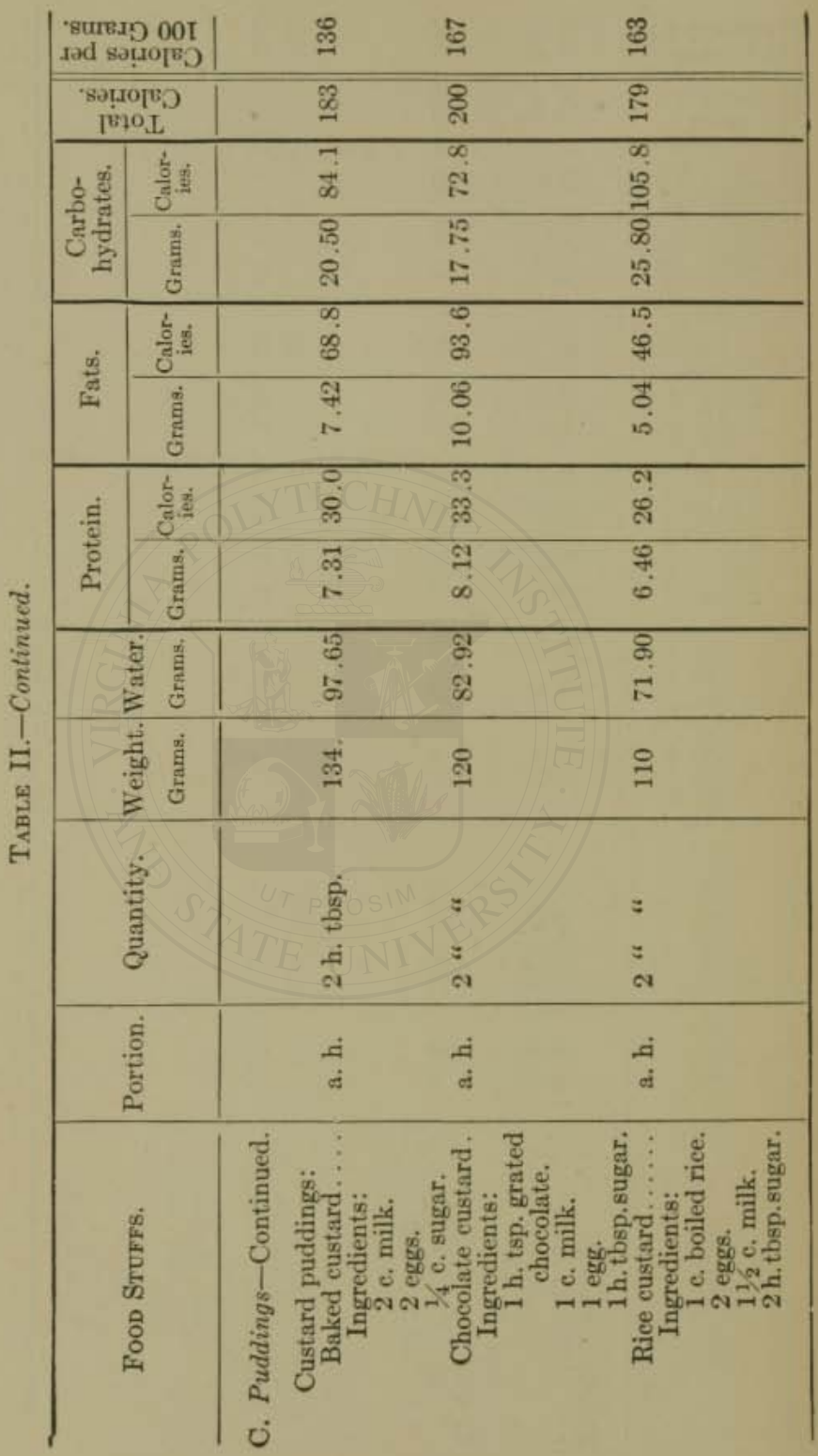




\section{PREPARED FOODS-EDIBLE PORTION 45}

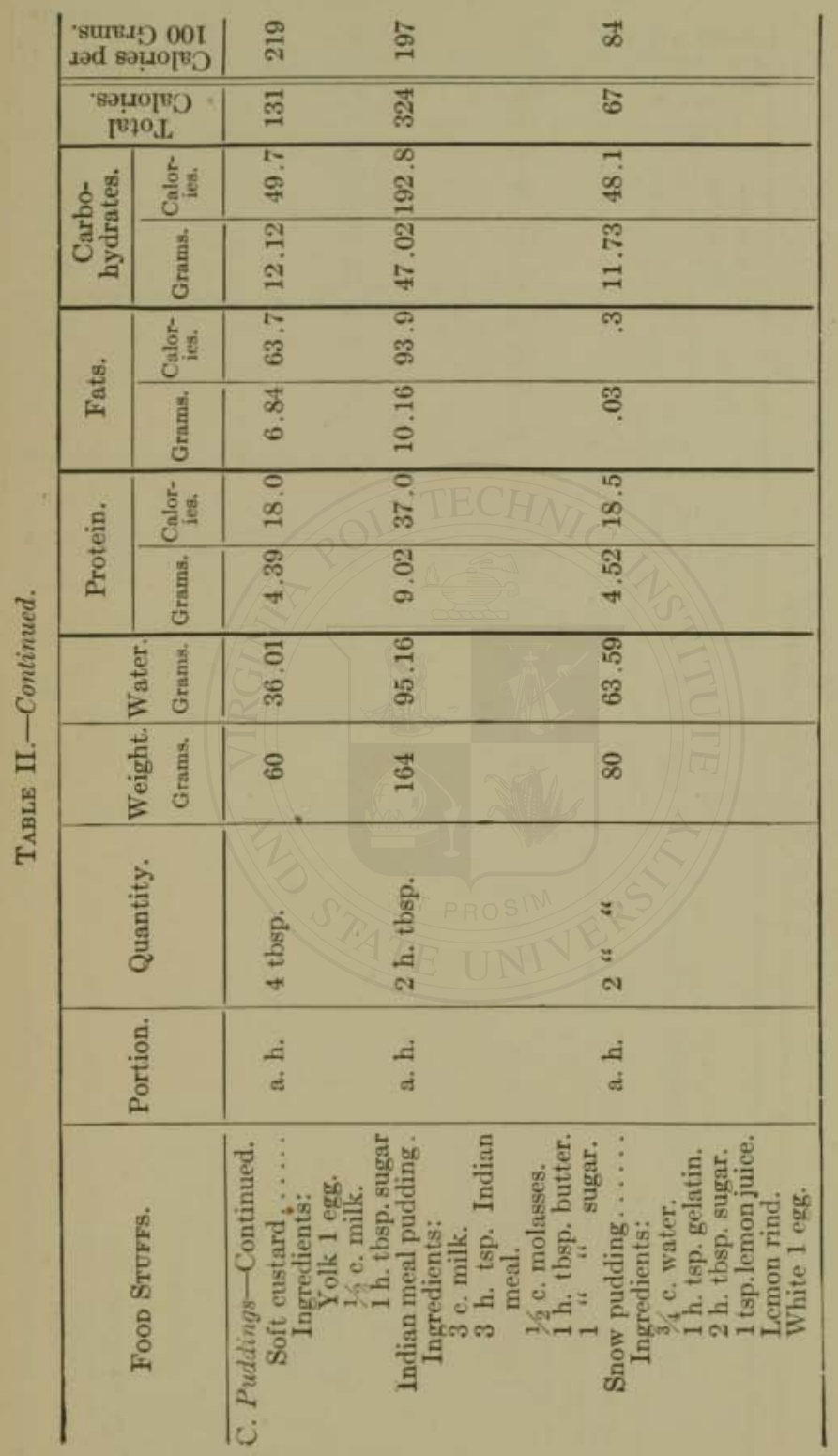


FOOD VALUES

\begin{tabular}{|c|c|c|c|}
\hline \multirow{2}{*}{ 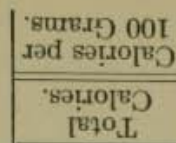 } & 怘 & กิ & 궉요 \\
\hline & ลี & 욕 & $\underset{7}{212}$ \\
\hline & न! & क & लूढ \\
\hline s. & क & $\stackrel{\varrho}{\varrho}$ & कृष्త \\
\hline 预育 & ลุ & 贾 & $8 \%$ \\
\hline 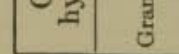 & สิ่ & $\stackrel{+}{\infty}$ & รี่กิ \\
\hline 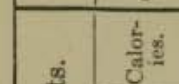 & 5 & $\vec{a}$ & $\begin{array}{l}0,0 \\
100\end{array}$ \\
\hline ही & $\stackrel{9}{-1}$ & क्षै & $8 R$ \\
\hline 立高 & क & ? & काज \\
\hline के हूँ & is & $\overline{\text { जे }}$ & 윰ำ \\
\hline 安 & $\bar{\infty}$ & $\$$ & ల్ల \\
\hline$\stackrel{\text { D }}{2}$ & ti & R & 188 \\
\hline 苟 & $\exists$ & $\stackrel{8}{\circ}$ & ్ㅐㄴㅝ \\
\hline $\begin{array}{l}\dot{3} \\
\text { है } \\
\text { है }\end{array}$ & $\begin{array}{l}\dot{1} \\
\stackrel{1}{2} \\
\dot{1} \\
\infty\end{array}$ & $\begin{array}{l}= \\
= \\
\therefore\end{array}$ & 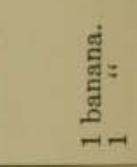 \\
\hline 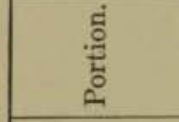 & $\dot{~}$ & में & $\begin{array}{l}\dot{L} \dot{ } \\
\text { di }\end{array}$ \\
\hline 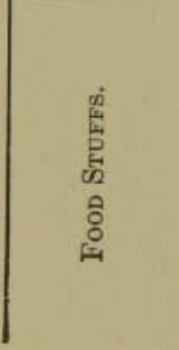 & 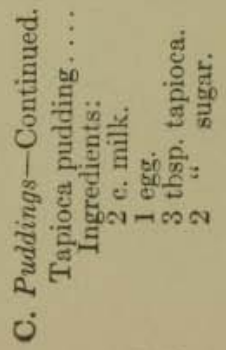 & 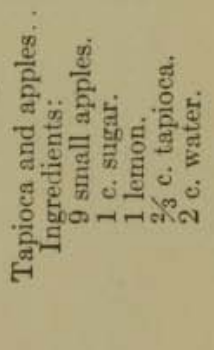 & 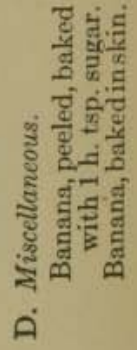 \\
\hline
\end{tabular}


PREPARED FOODS-EDIBLE PORTION 47

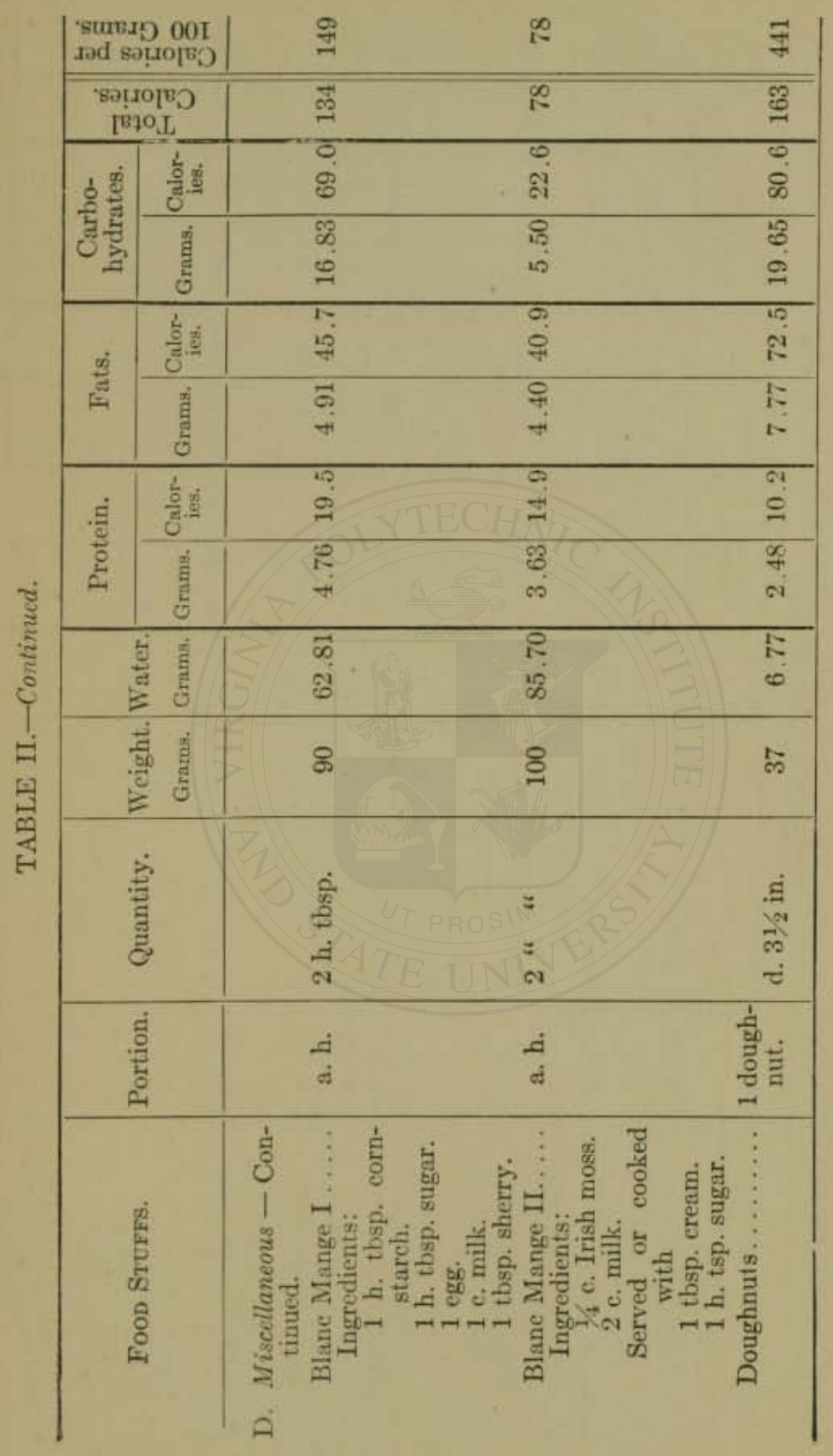


FOOD VALUES

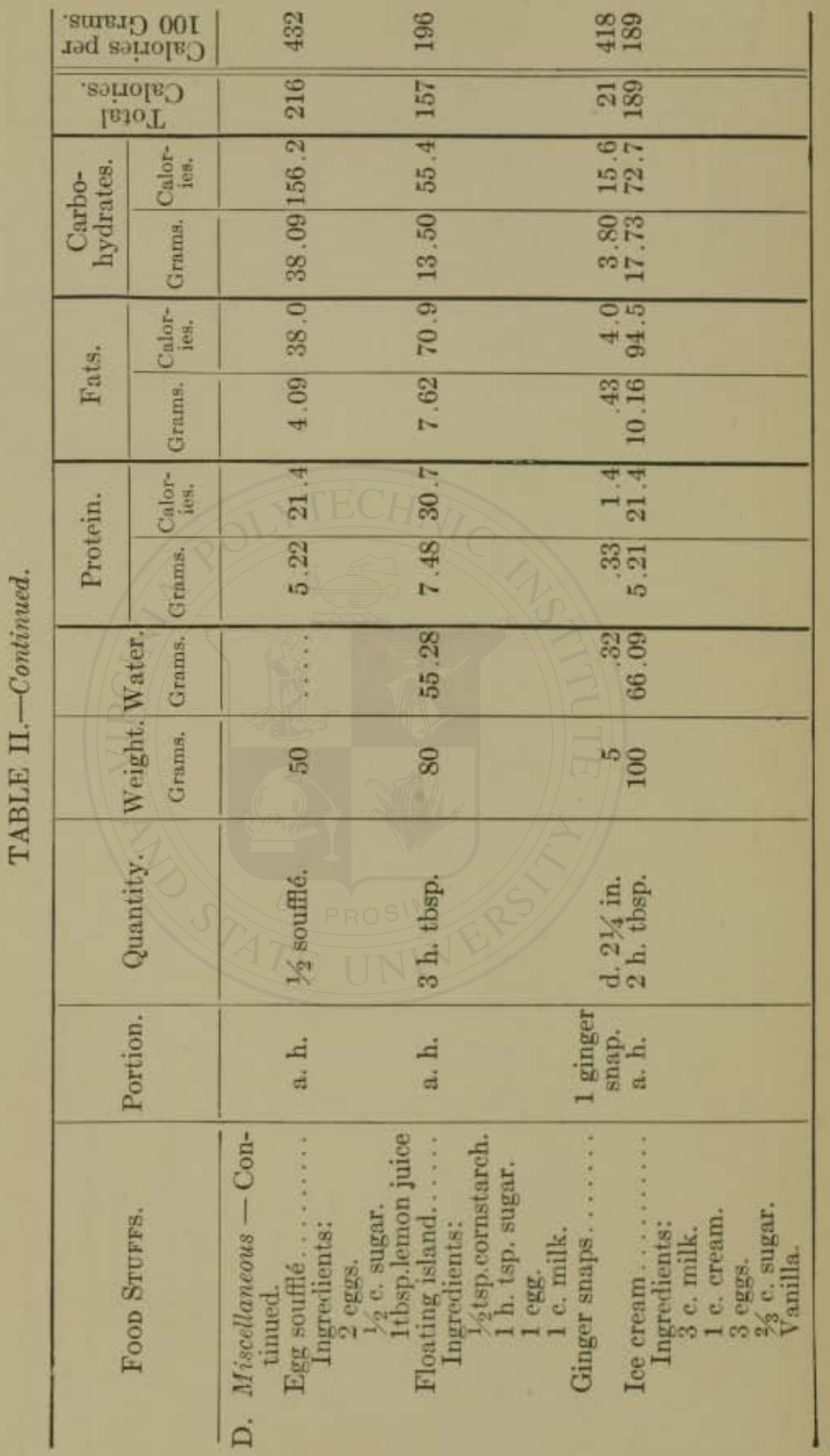


PREPARED FOODS-EDIBLE PORTION 49

\begin{tabular}{|c|c|c|c|c|}
\hline \multicolumn{2}{|c|}{ 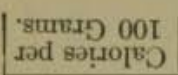 } & 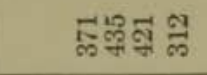 & $\Xi$ & ฬึ \\
\hline \multicolumn{2}{|c|}{ 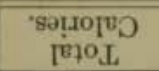 } & 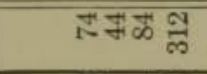 & Бे & 단 \\
\hline \multirow{2}{*}{ o } & & 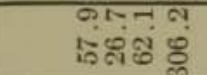 & $\stackrel{5}{15}$ & ○ \\
\hline & & 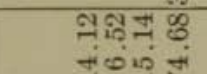 & $\begin{array}{l}10 \\
\infty \\
\infty\end{array}$ & : \\
\hline \multirow{3}{*}{ sin } & & लन-न न & 0 & 7 \\
\hline & 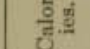 & oIg & $0^{\circ}$ & 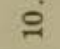 \\
\hline & & 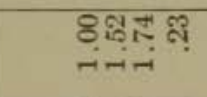 & 89 & $\stackrel{9}{-}$ \\
\hline \multirow{2}{*}{ 这 } & $\frac{1}{b}$ & $\begin{array}{l}\text { बानक क } \\
\text { Novis कo }\end{array}$ & @i & $\begin{array}{l}\text { N. } \\
i\end{array}$ \\
\hline & & Qृषन के & $\begin{array}{l}\overrightarrow{0} \\
\text { ம. }\end{array}$ & F \\
\hline \multirow{2}{*}{\multicolumn{2}{|c|}{$\stackrel{d}{=}$}} & 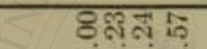 & ஜ़ & $\overline{6}$ \\
\hline & & ๓ー- ฌ & हं & \\
\hline \multicolumn{2}{|c|}{ 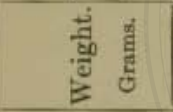 } & ి요 §్స & 18 & $=$ \\
\hline \multicolumn{2}{|c|}{ 总 } & 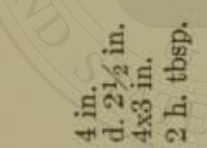 & 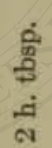 & $\begin{array}{l}\text { ने } \\
\text { d }\end{array}$ \\
\hline \multicolumn{2}{|r|}{ : } & & $\dot{d}$ & 용 \\
\hline \multicolumn{2}{|c|}{ 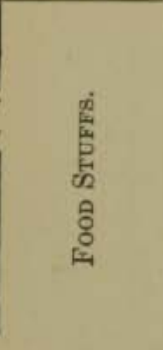 } & 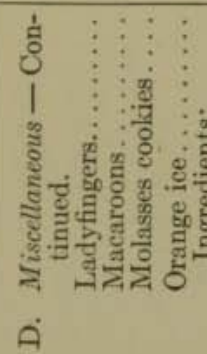 & 至 & $\begin{array}{l}\vdots \\
\vdots \\
\vdots \\
0 \\
\frac{0}{8} \\
8 \\
0 \\
\vdots \\
\text { कू } \\
\text { के }\end{array}$ \\
\hline
\end{tabular}




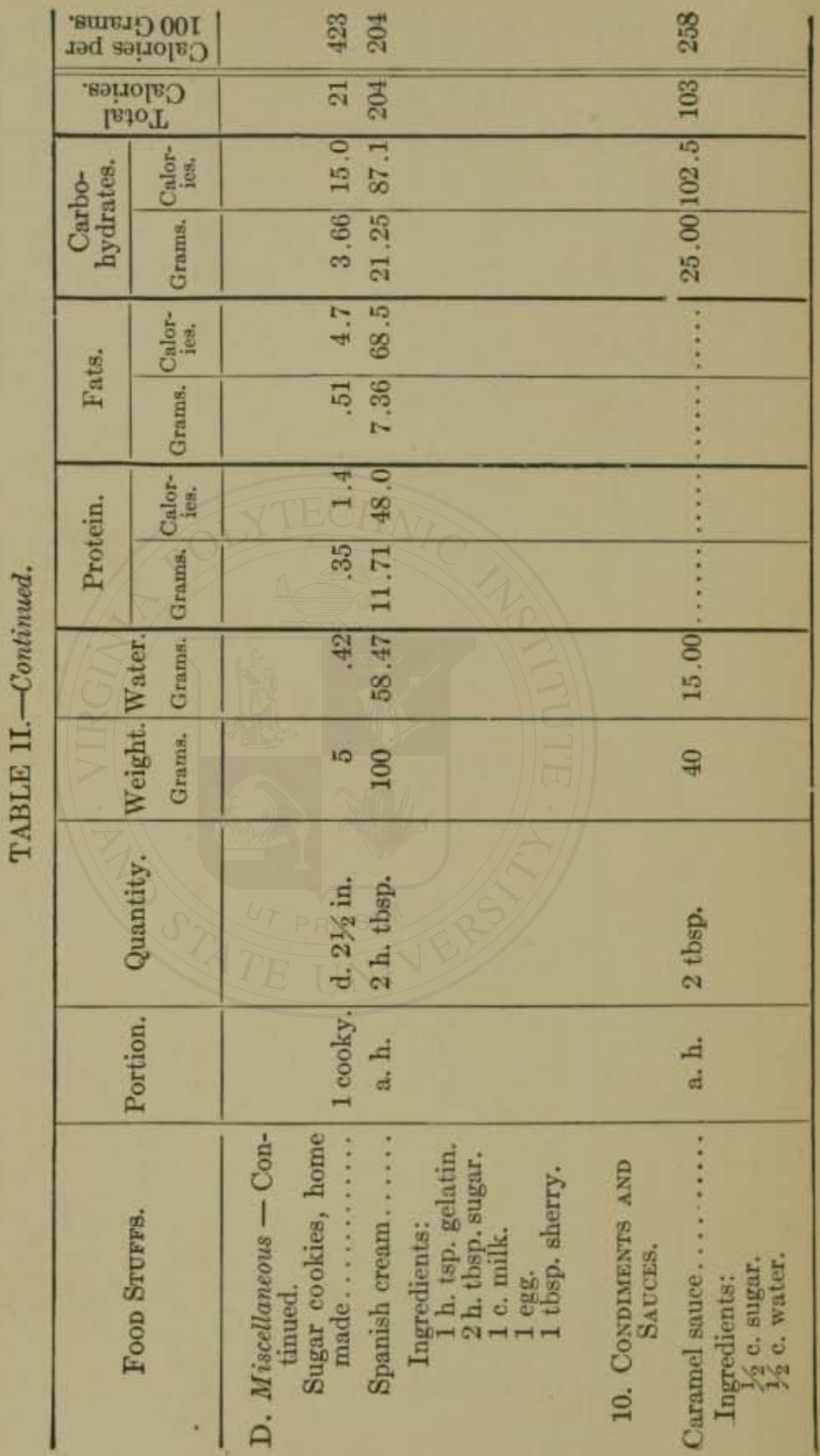


PREPARED FOODS-EDIBLE PORTION 51

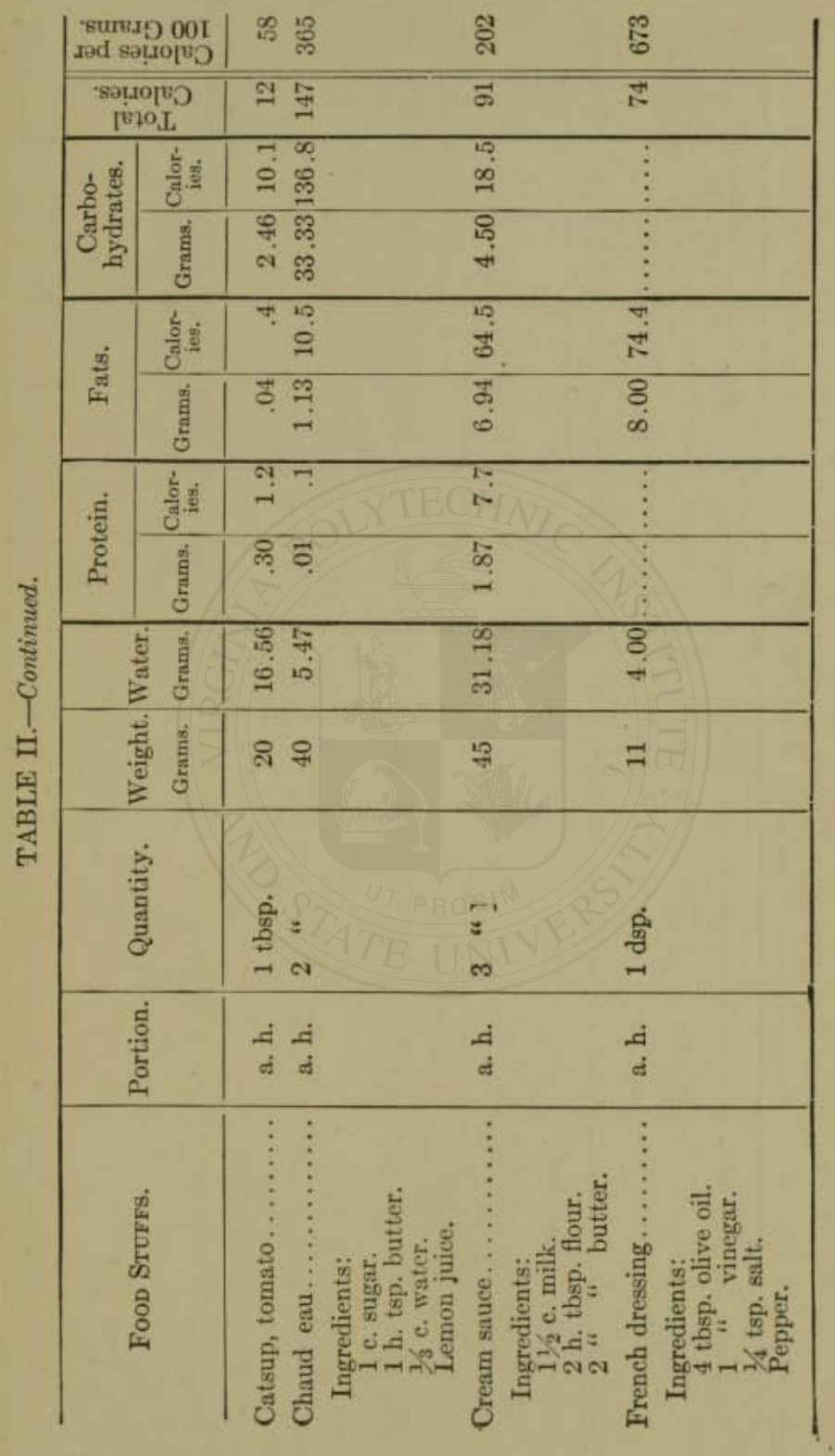




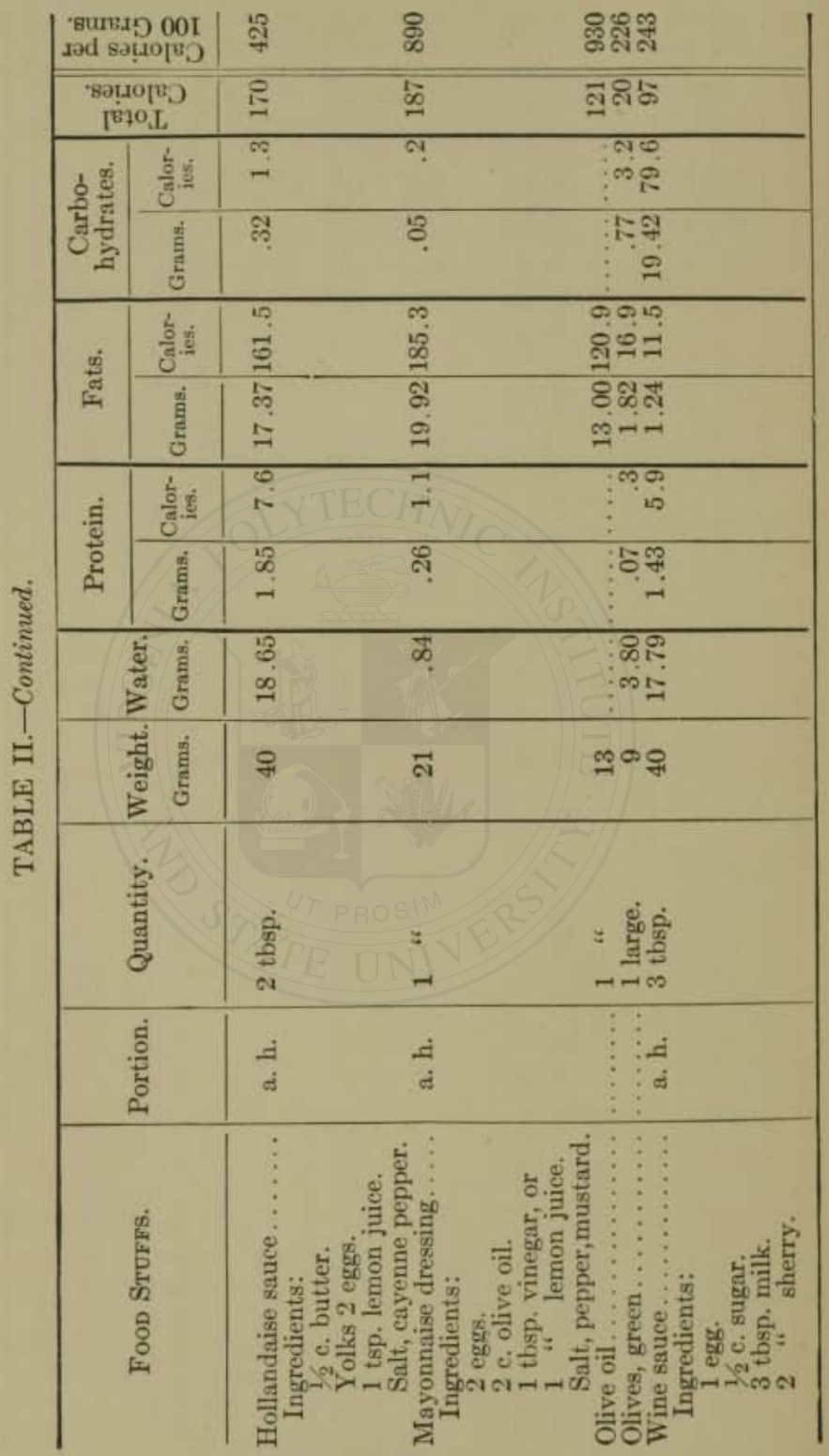




\section{PREPARED FOODS-EDIBLE PORTION 53}

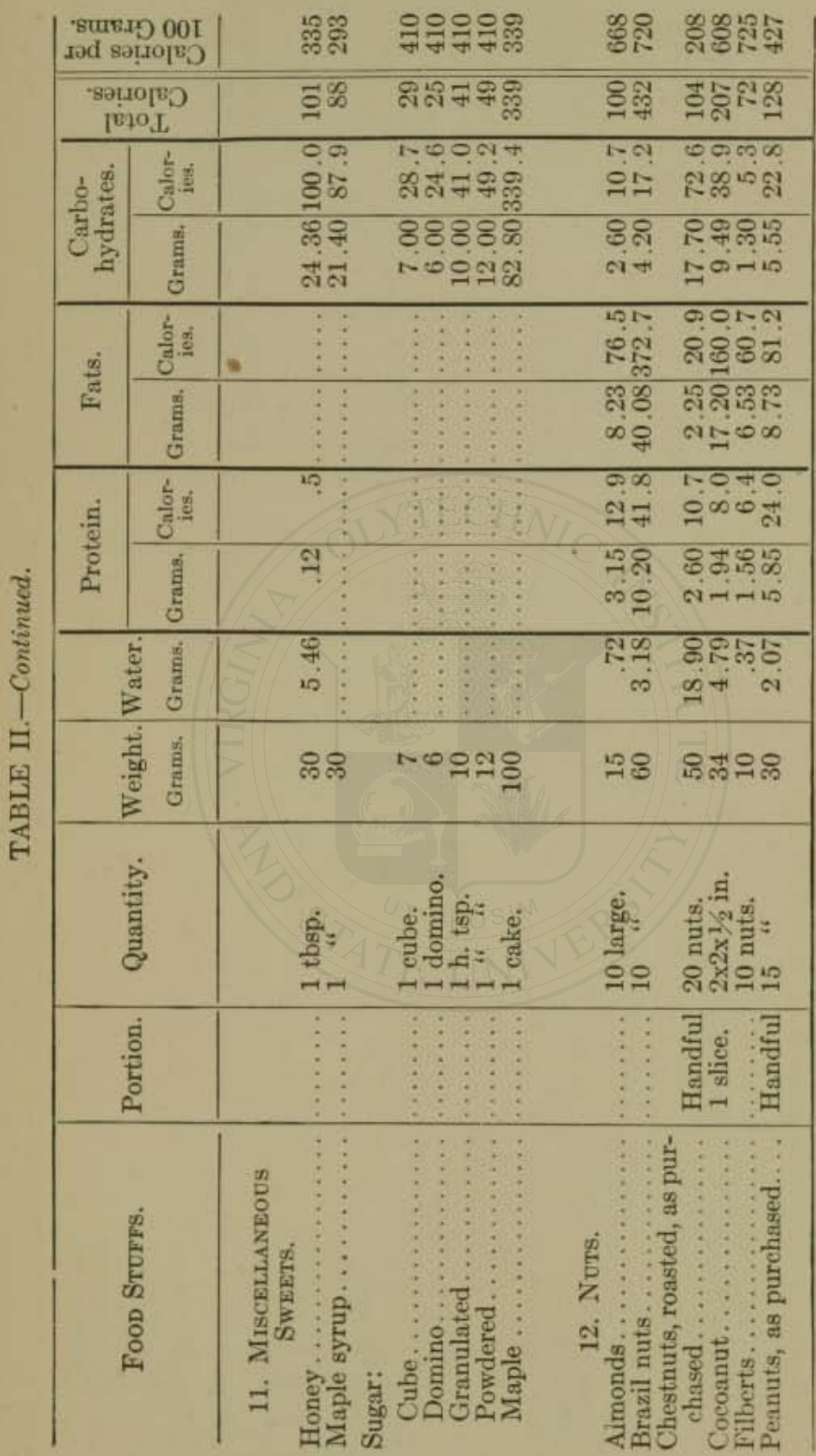




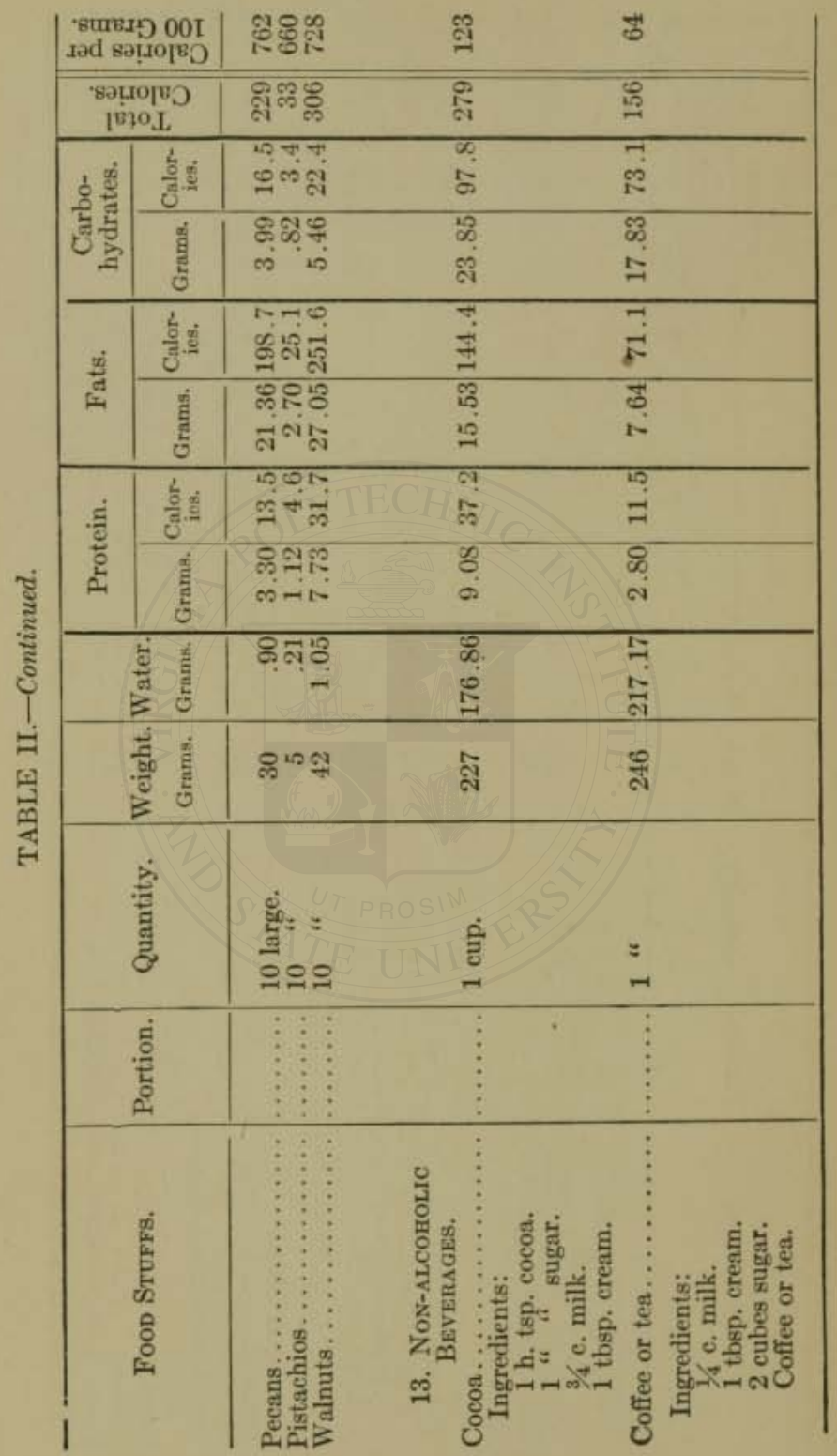




\section{PREPARED FOODS-EDIBLE PORTION $\mathbf{5 5}$}

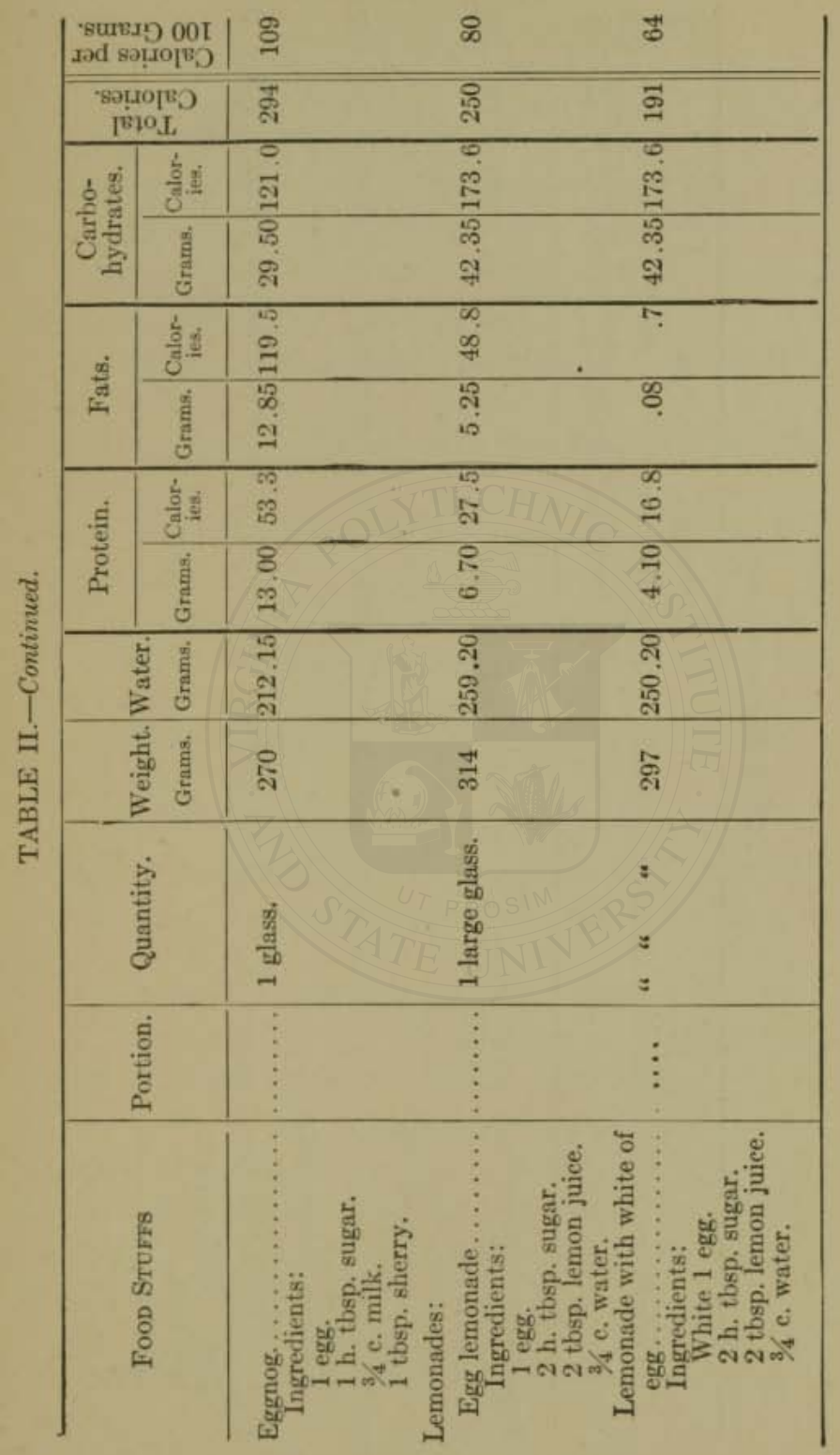




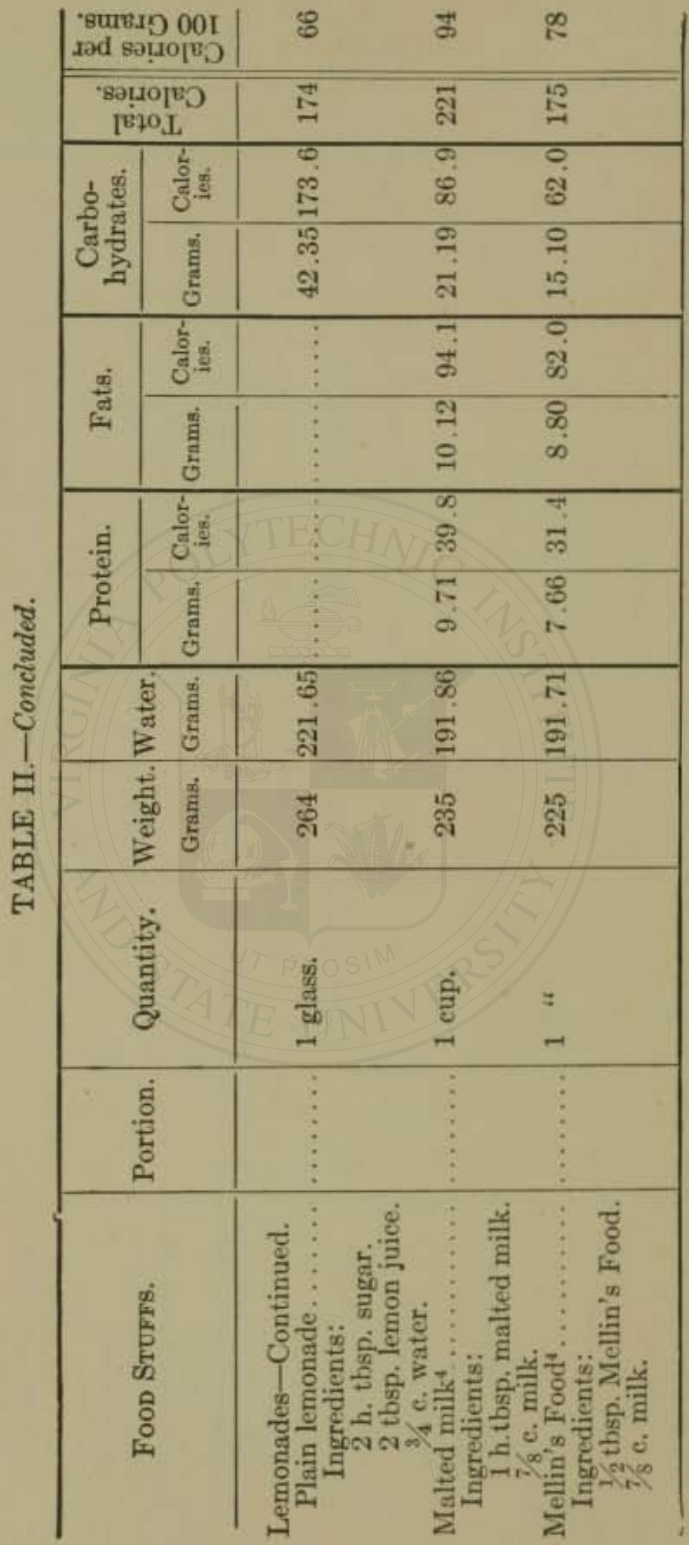




\section{REFFRENCES.}

1. Atwater and Bryant. "The Chemical Composition of American Food Materials." Bulletin No. 28 (revised), Office Experiment Station, United States Department of Agriculture, 1900.

2. DetTweiler. "Handbuch der Ernährrungstherapie und Diätetik,"' v. Leyden, Bd. II, 1904.

3. Fisher. "A Graphie Method in Practieal Dietetics," 1907.

4. Hutchison. "Food and the Principles of Dieteties," 1908.

5. Kellogg. "The Battle Creek Sanitarium Diet List," 1909.

6. Langworthy. "Use of Fruit as Food." Farmers" Bulletin, No. 293, United States Department of Agrieulture, 1907.

7. Monthly Bulletin. Massachusetts State Board of Health, Oct., 1910.

8. Richmond. "'Dairy Chemistry,"' 1899.

9. ScHWENKENBEcHER. "Die Nährwerthberechnung tischfertiger Speisen. Zeit. für diät. und physik. Therapie, IV, 1901.

10. SNyder. "Dairy Chemistry," 1906.

11. Wriliams. "The Composition of Cooked Vegetables." Journ. Chem. Soc. Trans., LXI, 1892, 226.

12. "The Composition of Cooked Fish." Journ. Chem. Soc. Trans., LXVI, 1897, 649.

13. Woods AND SNyder. "Cereal Breakfast Foods." Farmers' Bulletin, No. 249, United States Department of Agriculture, 1906.

14. Woons. "Meats: Composition and Cooking." Farmers' Bulletin, No. 34, United States Department of Agriculture, 1904. 


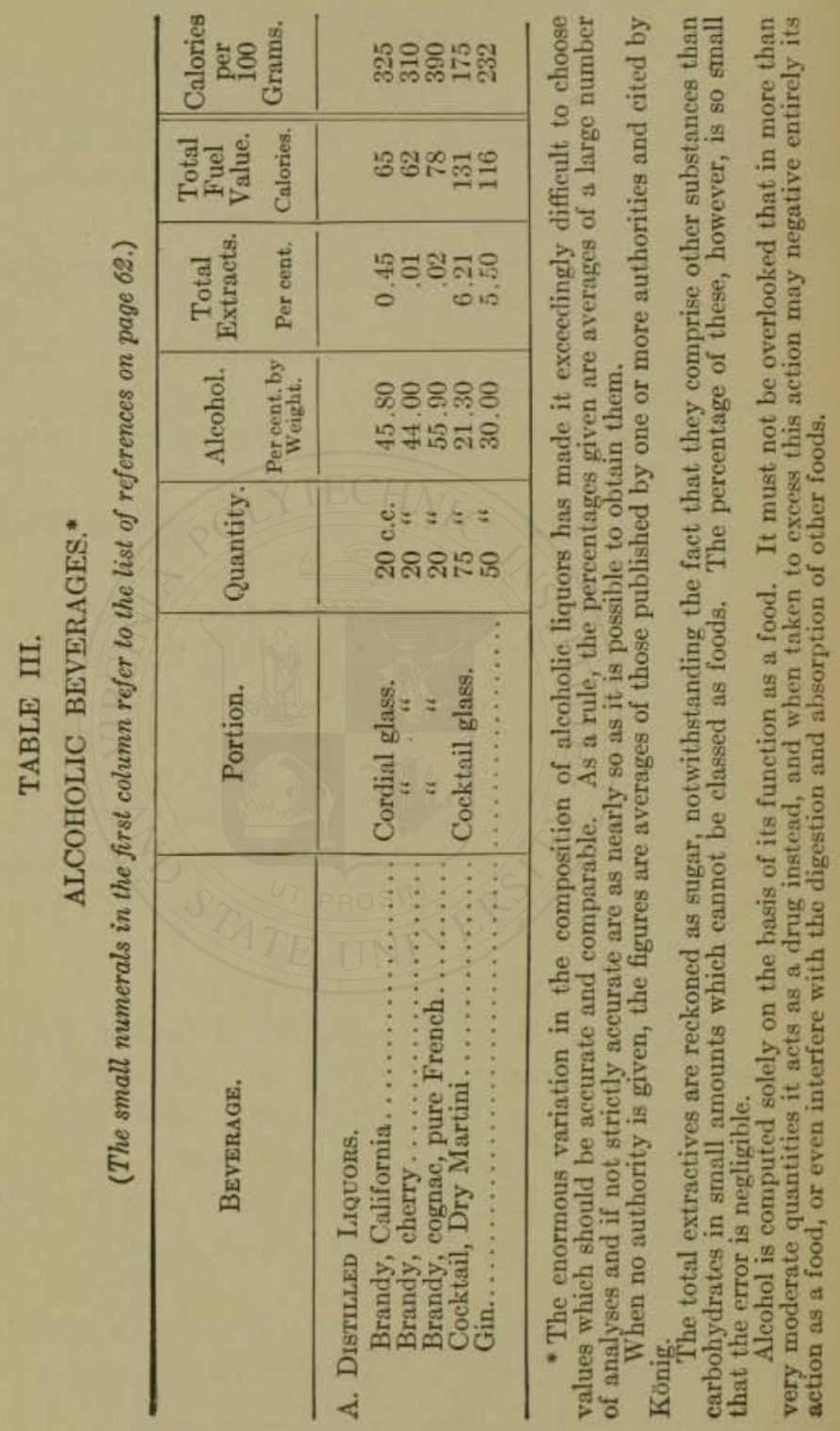




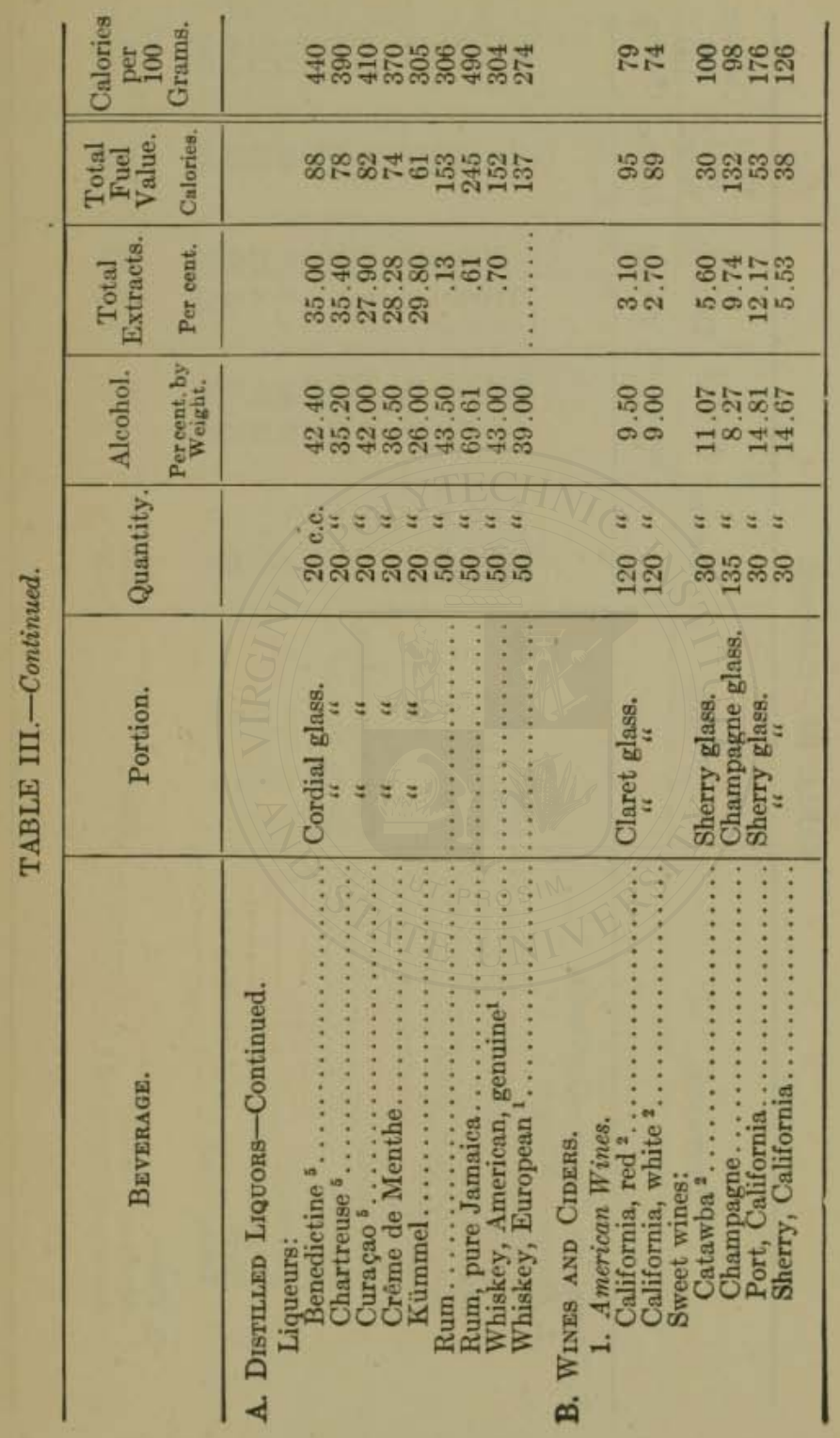




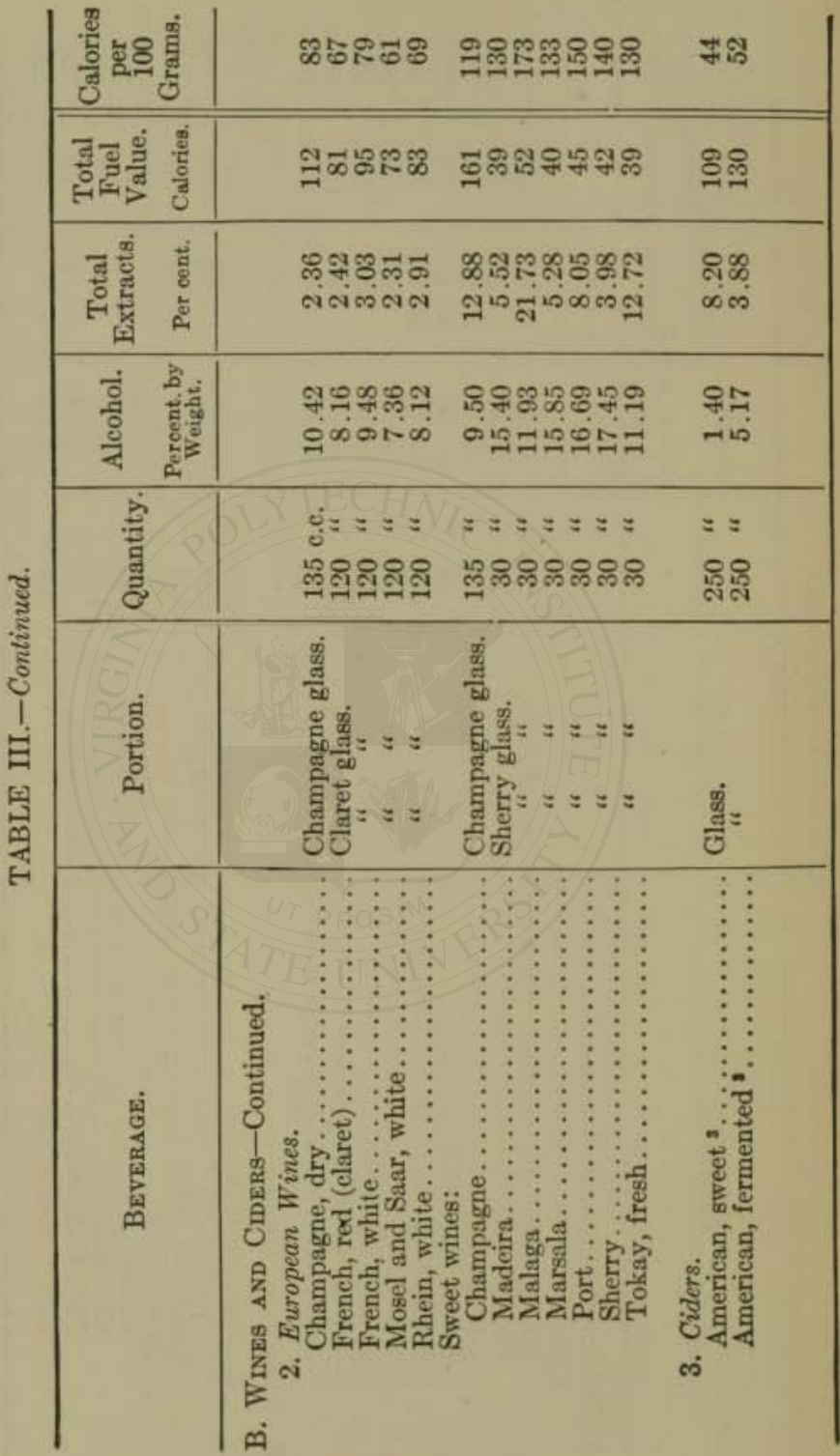


ALCOHOLIC BEVERAGES

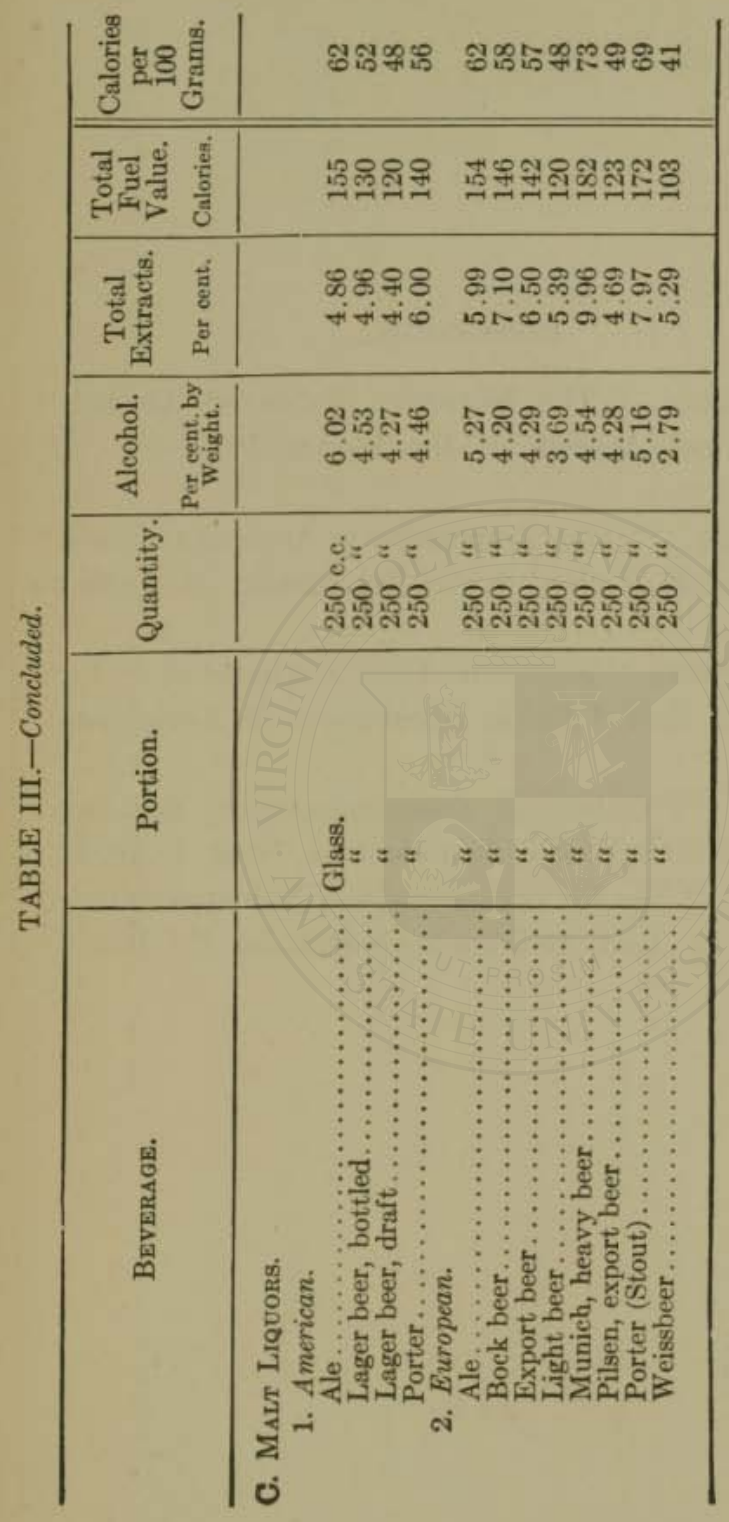


REFERENCES.

1. Atwater. "The Nutritive Value of Alcohol," "Physiological Aspects of the Liquor Problem," II, 1903.

2. Bigelow. "The Composition of American Wines," Bulletin No. 59, United States Department of Agriculture, 1900.

3. Crompton. "Foods and Food Adulterants," Bulletin No. 13, United States Department of Agriculture, 1877.

4. KöNIG. "Chemische Zusammensetzung der menschlichen Nährungs- und Genussmittel,', Bd. I, 1903.

5. Rupp. "Die Untersuchung von Nahrungsmitteln, Genussmitteln und Gebrauchgegenstanden." Heidelberg, 1894. 
COMPOSITION OF AMERICAN FOODS 63

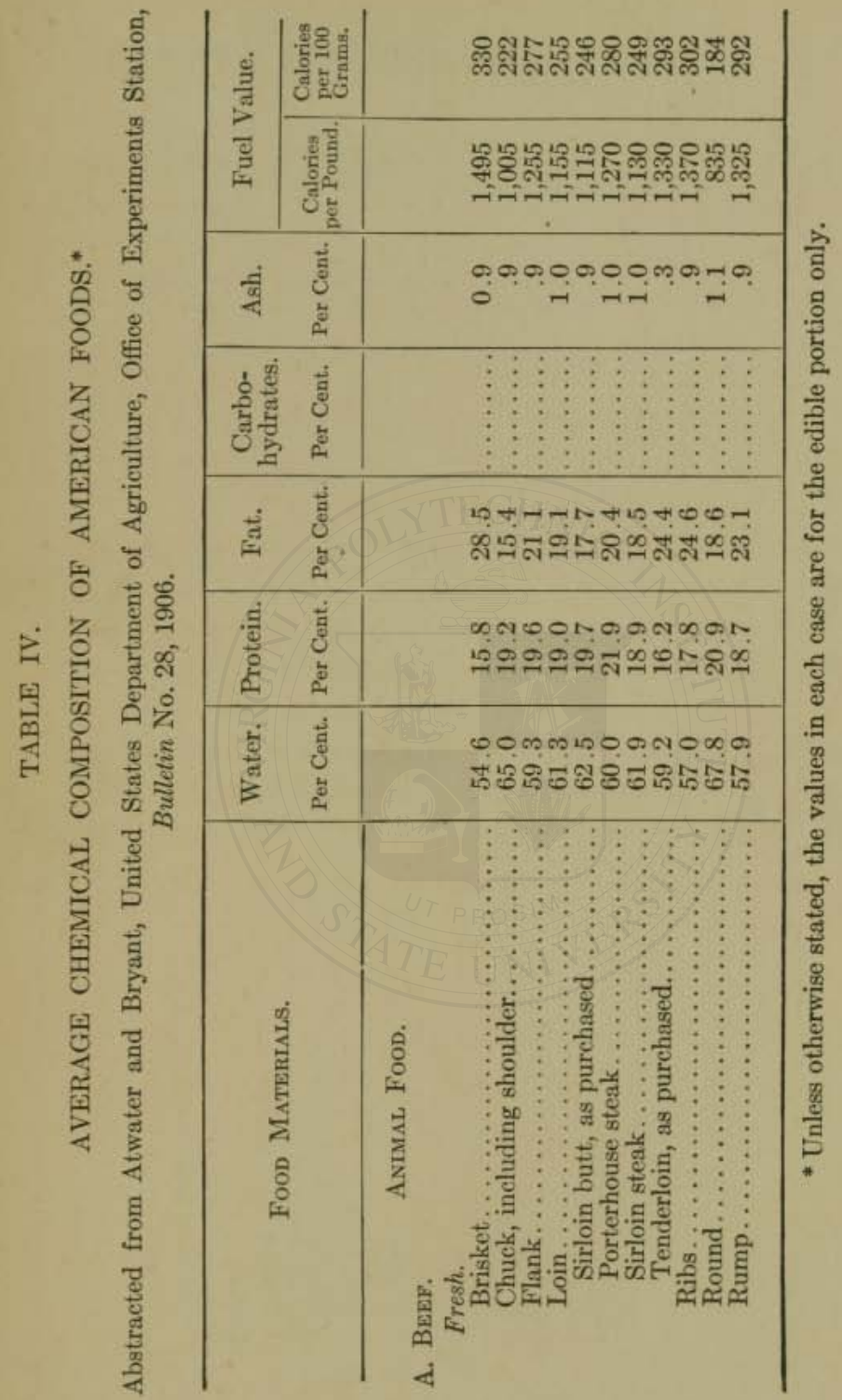




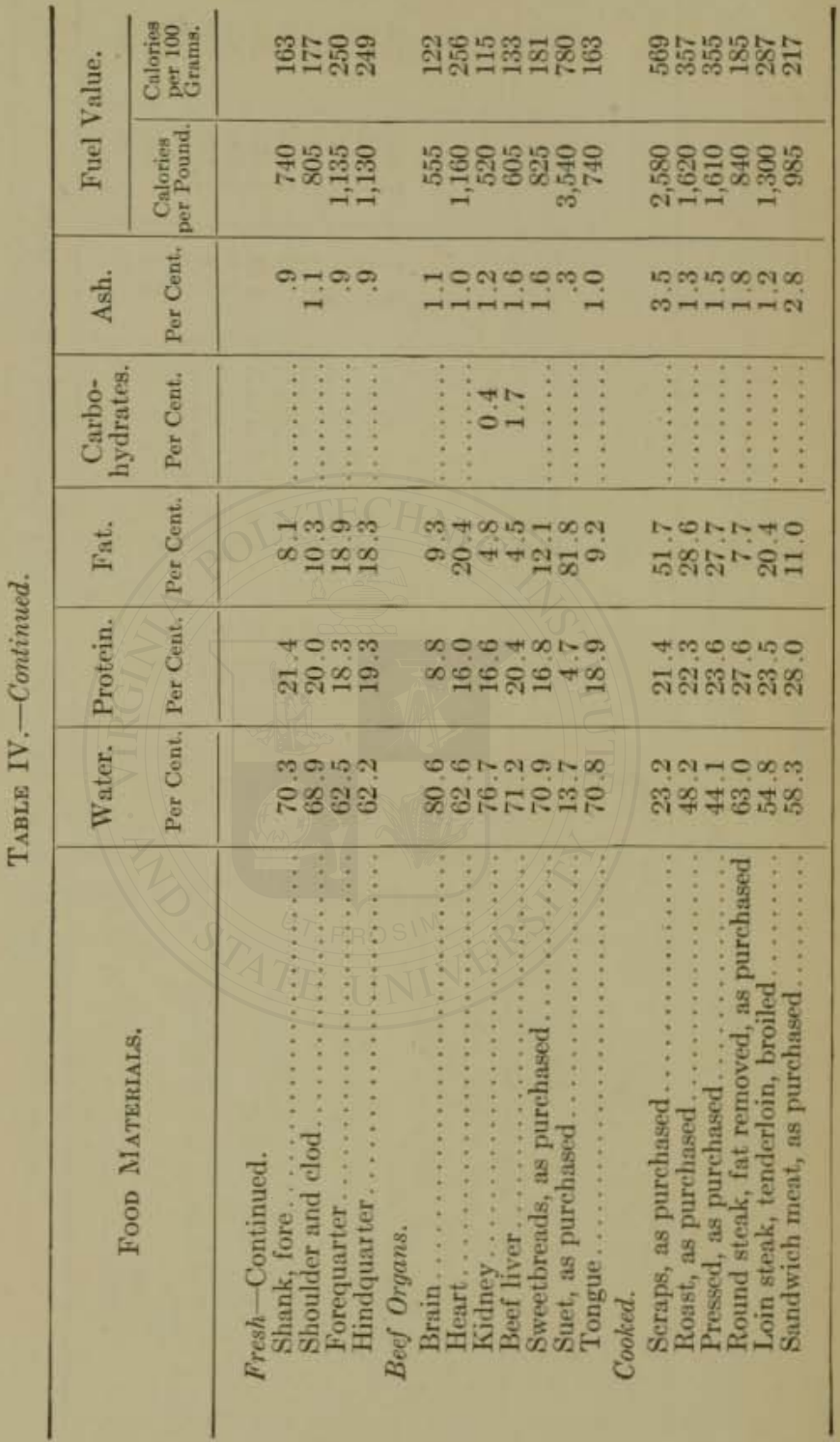




\section{COMPOSITION OF AMERICAN FOODS 65}

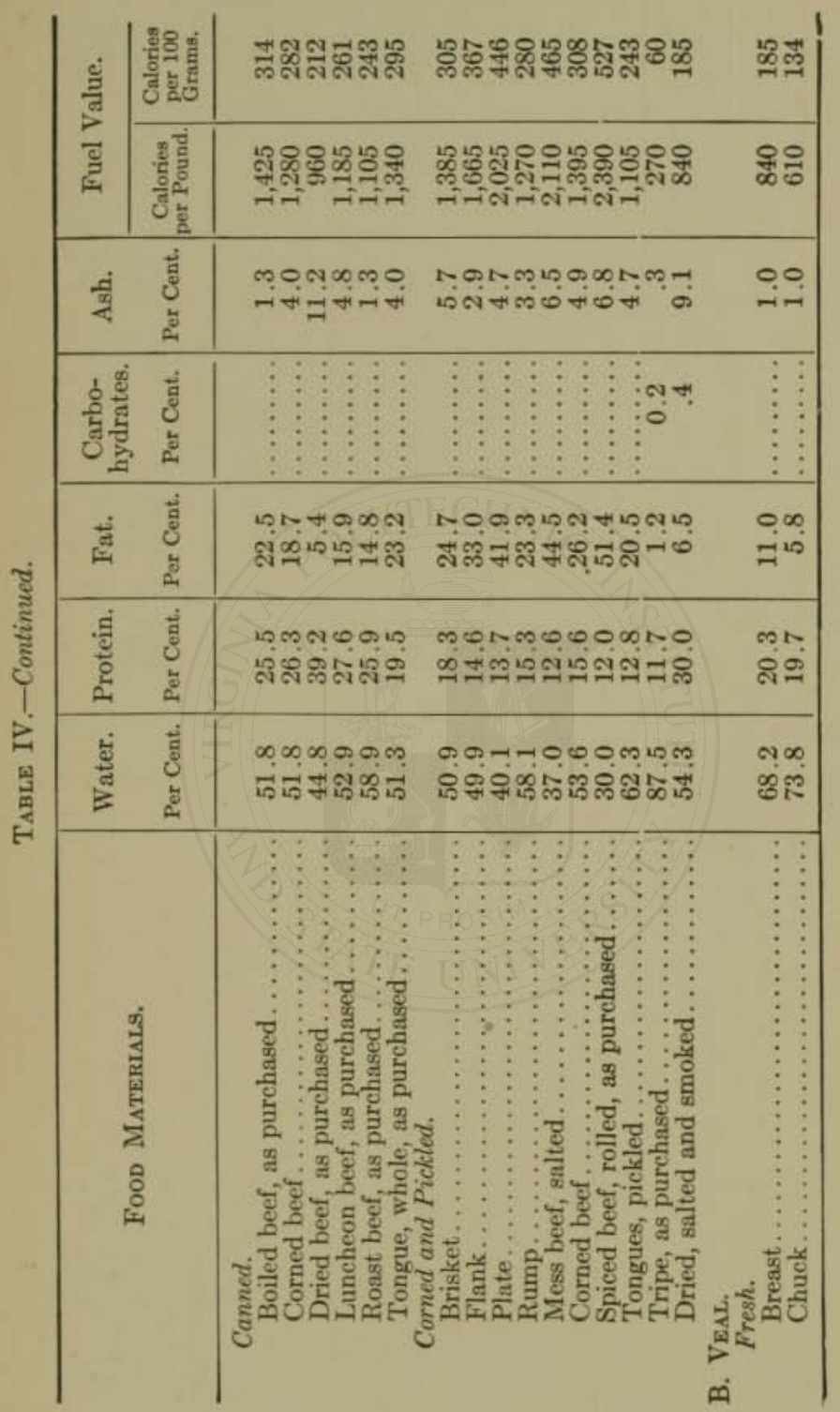




\begin{tabular}{|c|c|c|c|}
\hline हु & 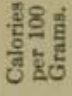 & 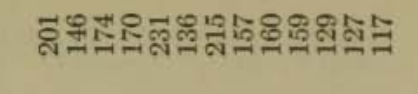 & 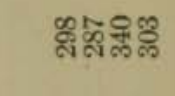 \\
\hline ङ & 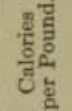 & 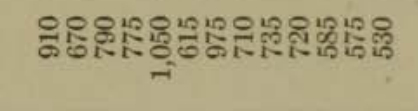 & 옹ำ \\
\hline 睭 & $\begin{array}{c}\vec{g} \\
\dot{b} \\
\dot{b}\end{array}$ & 0ேーーー0ー0.000000 & 0000 \\
\hline 官离 & 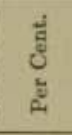 & 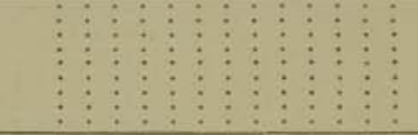 & $\vdots \vdots \vdots \vdots \vdots$ \\
\hline 鹿 & 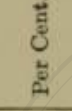 & 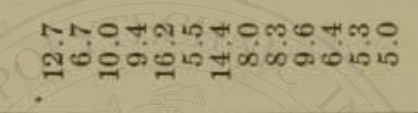 & फल्क \\
\hline$\frac{\dot{\Xi}}{\stackrel{5}{0}}$ & 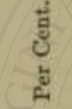 & 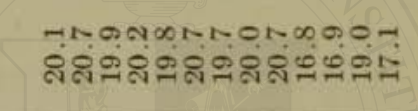 & SON \\
\hline$\frac{\dot{s}}{\xi}$ & 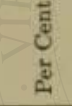 & 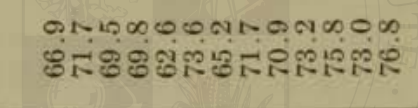 & 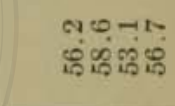 \\
\hline & 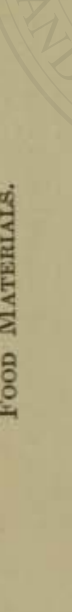 & 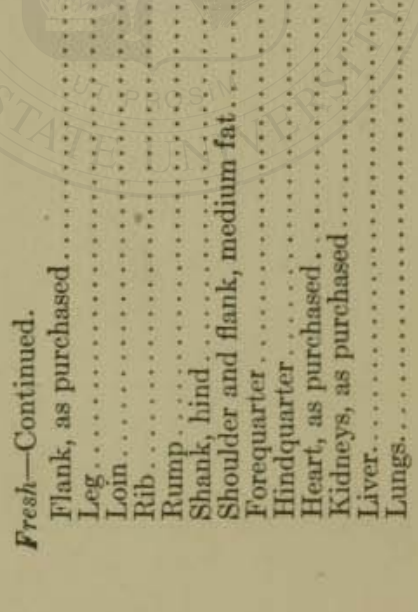 & 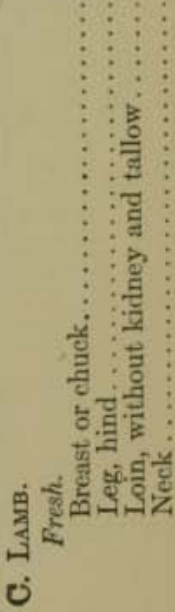 \\
\hline
\end{tabular}


COMPOSITION OF AMERICAN FOODS 67

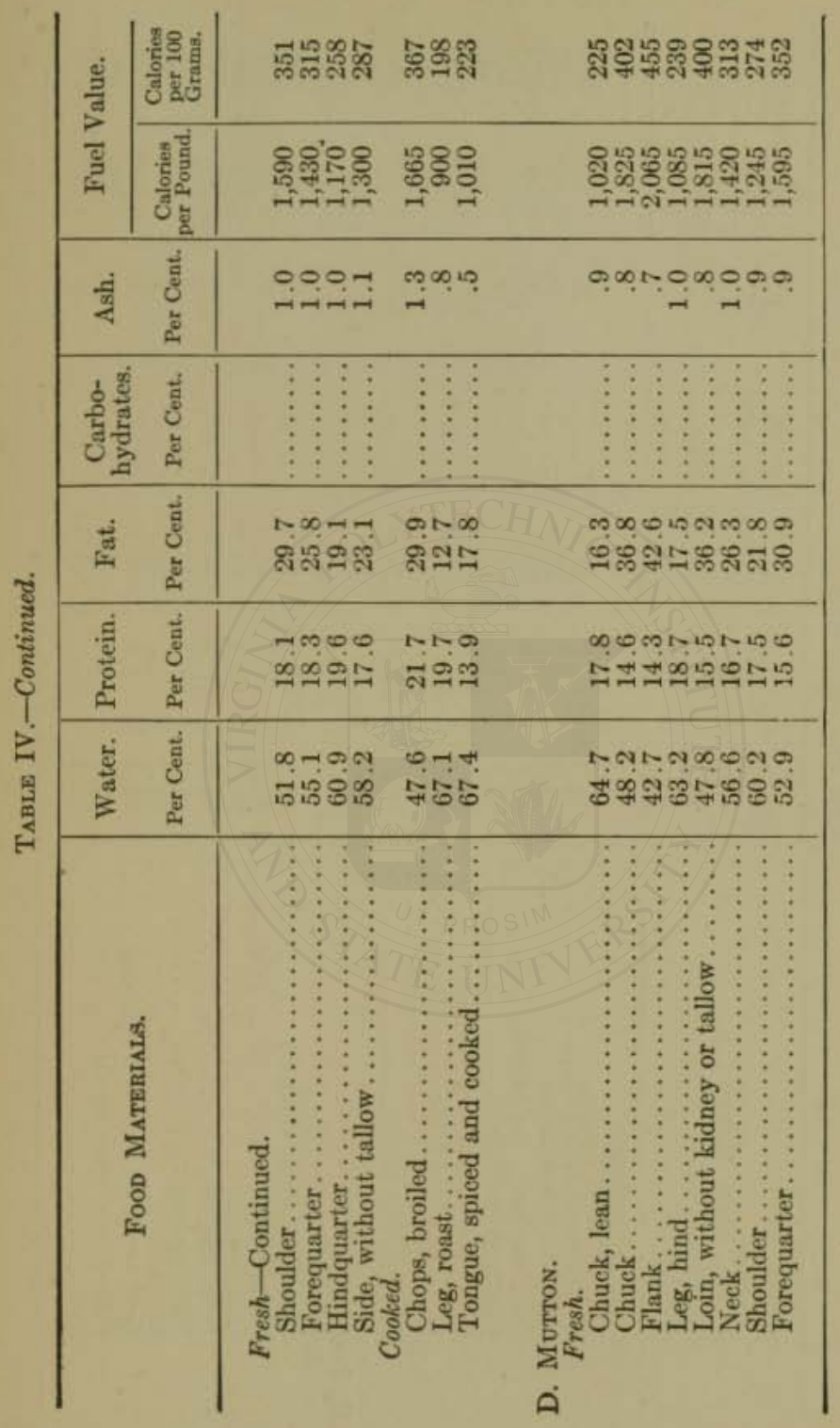




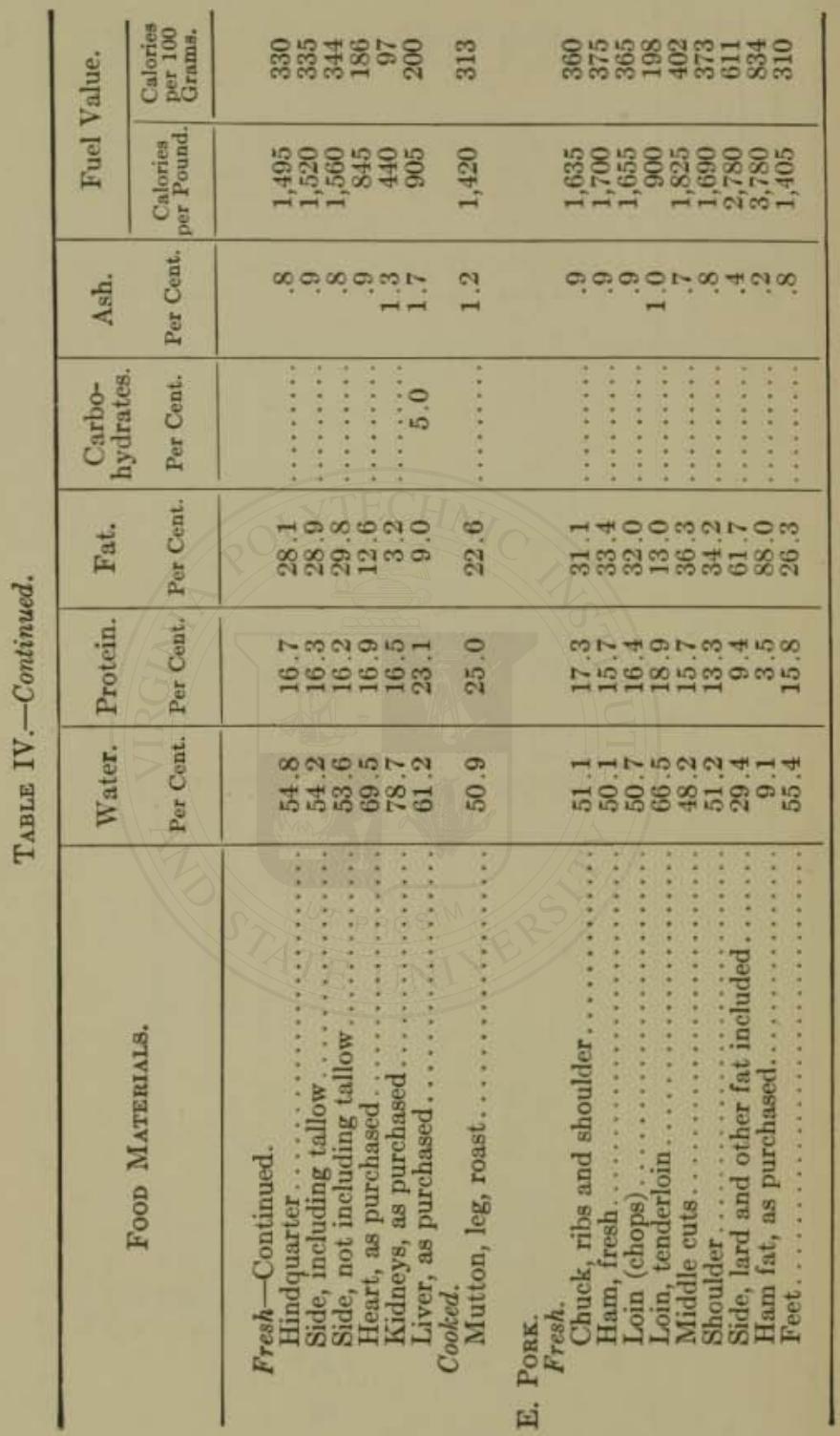


COMPOSITION OF AMERICAN FOODS 69

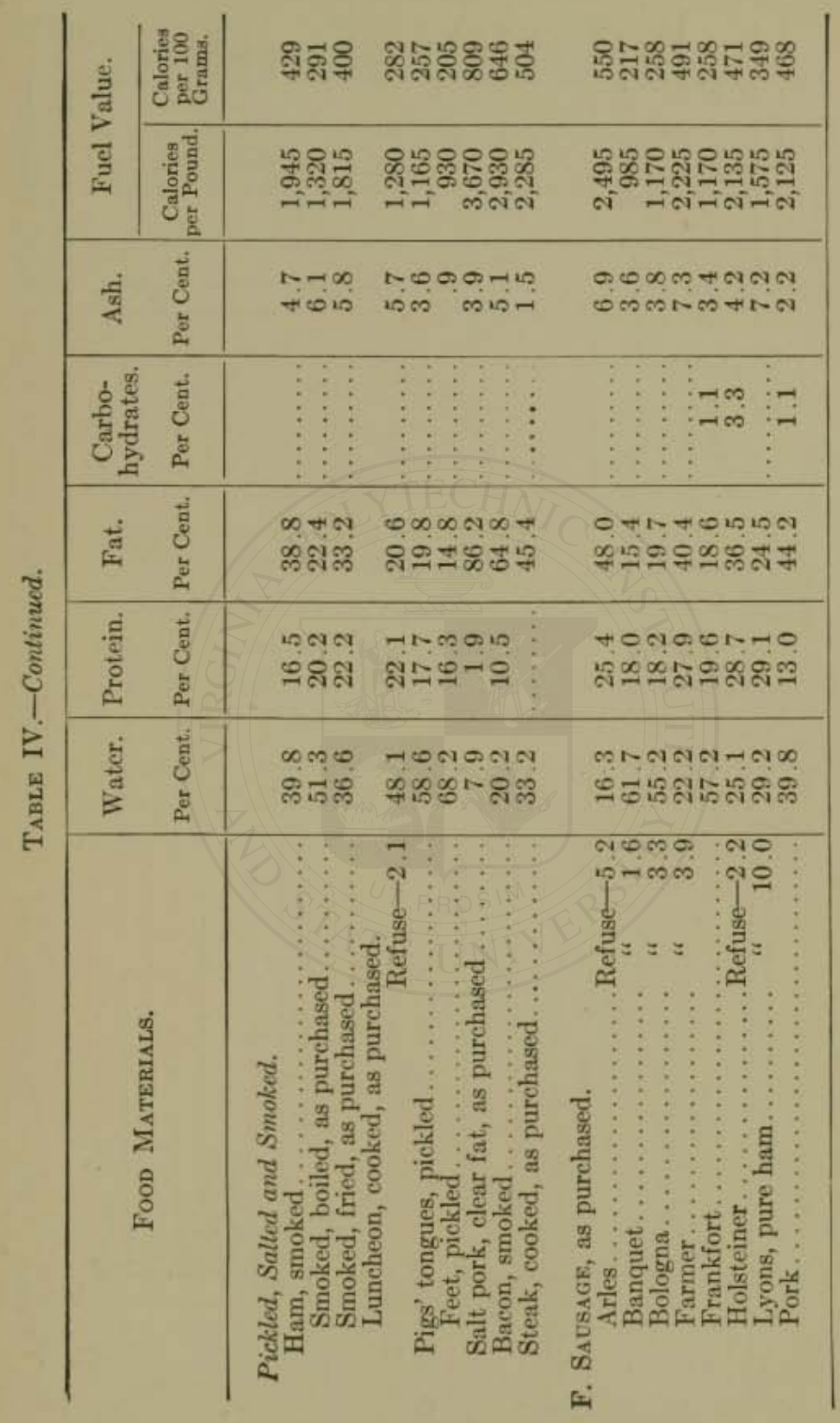




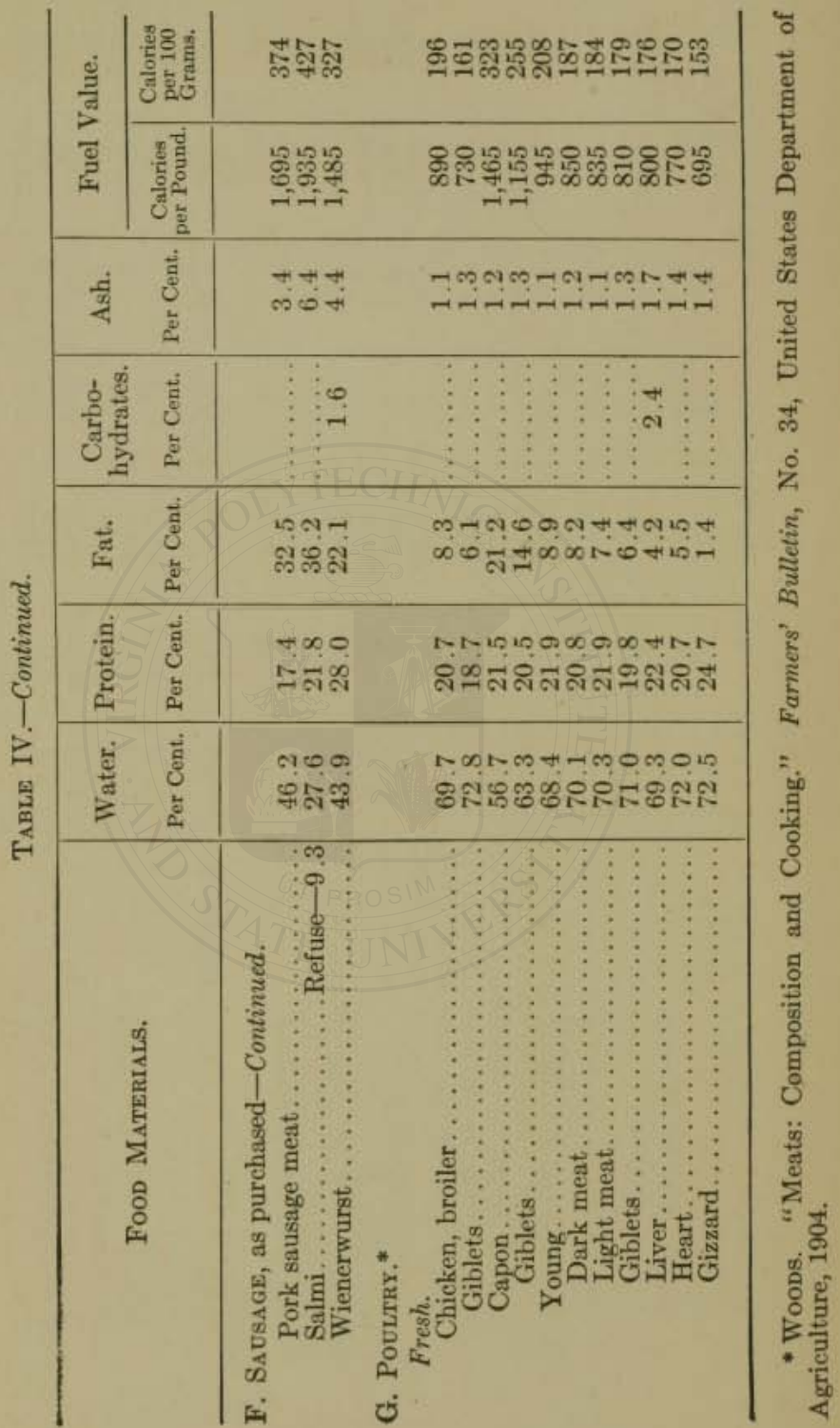




\section{COMPOSITION OF AMERICAN FOODS $\mathbf{7 1}$}

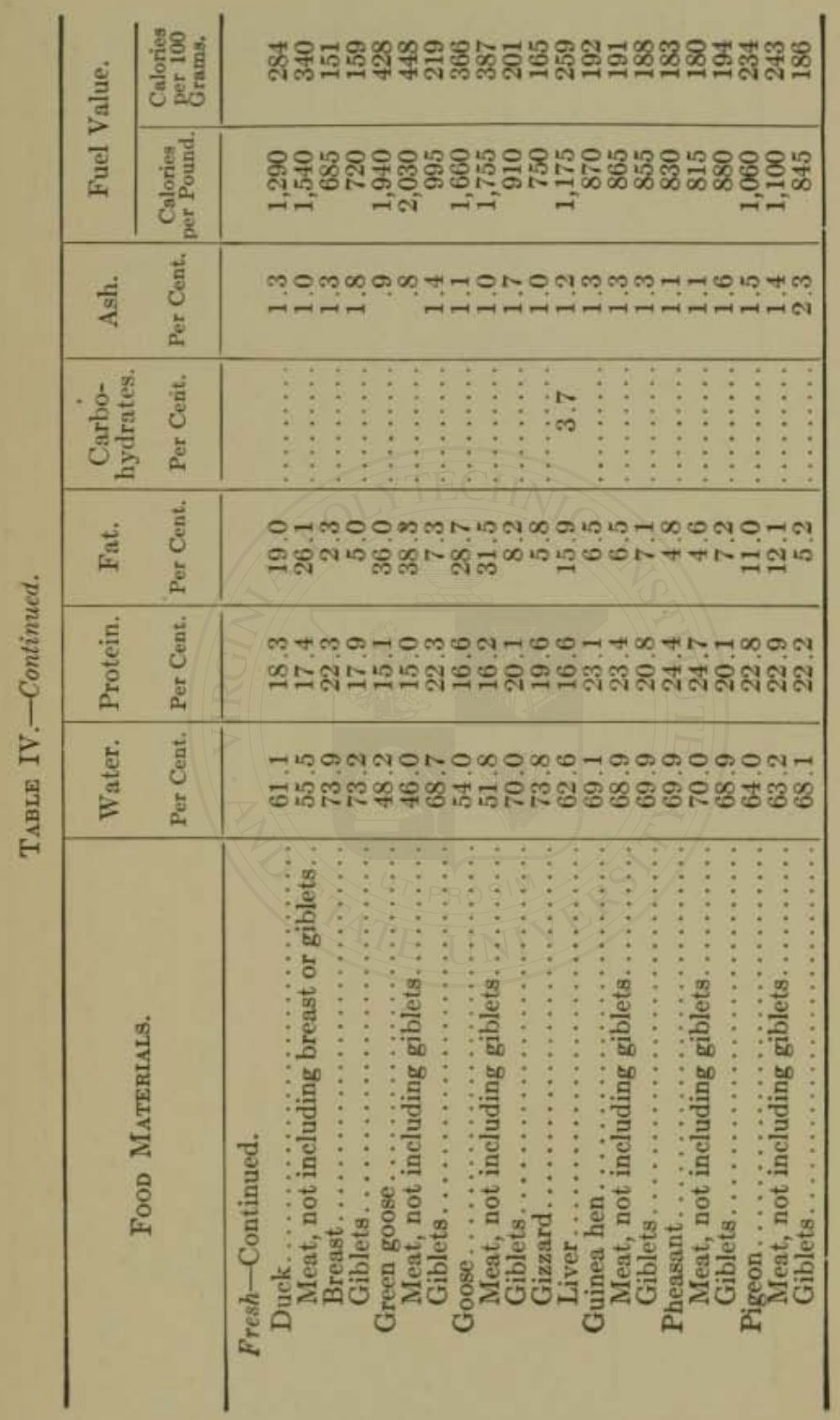




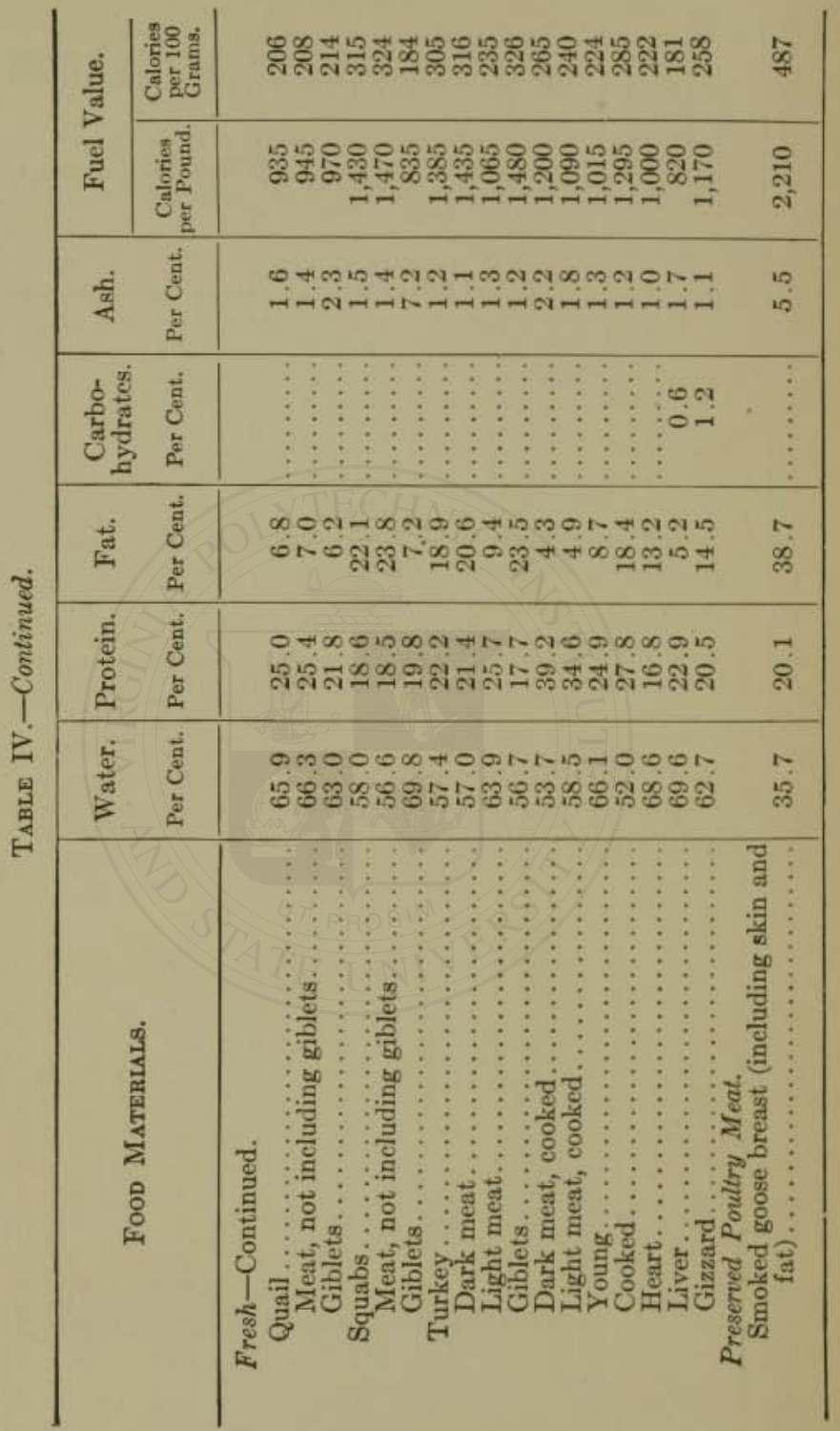


COMPOSITION OF AMERICAN FOODS

73

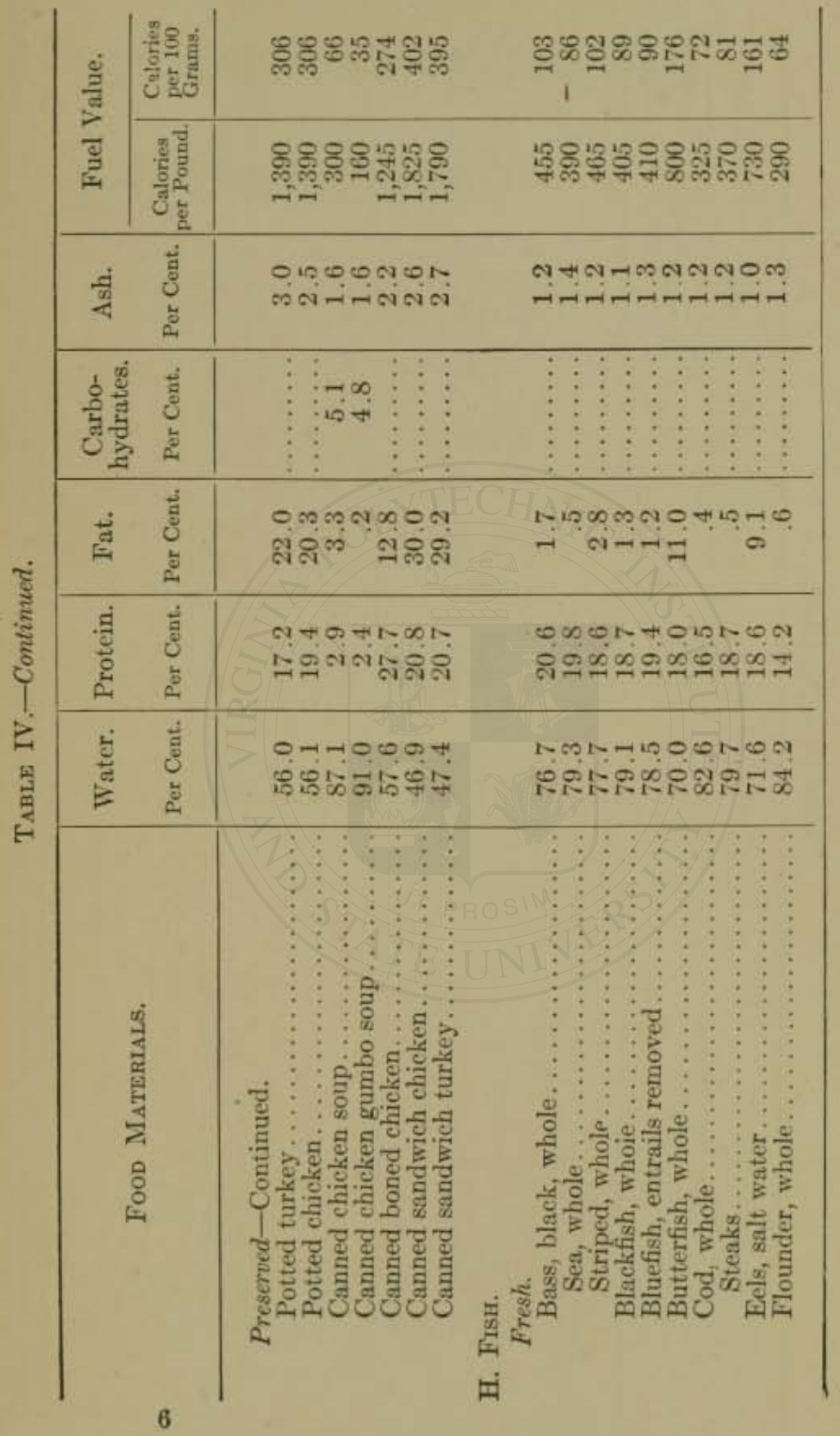




\section{FOOD VALUES}

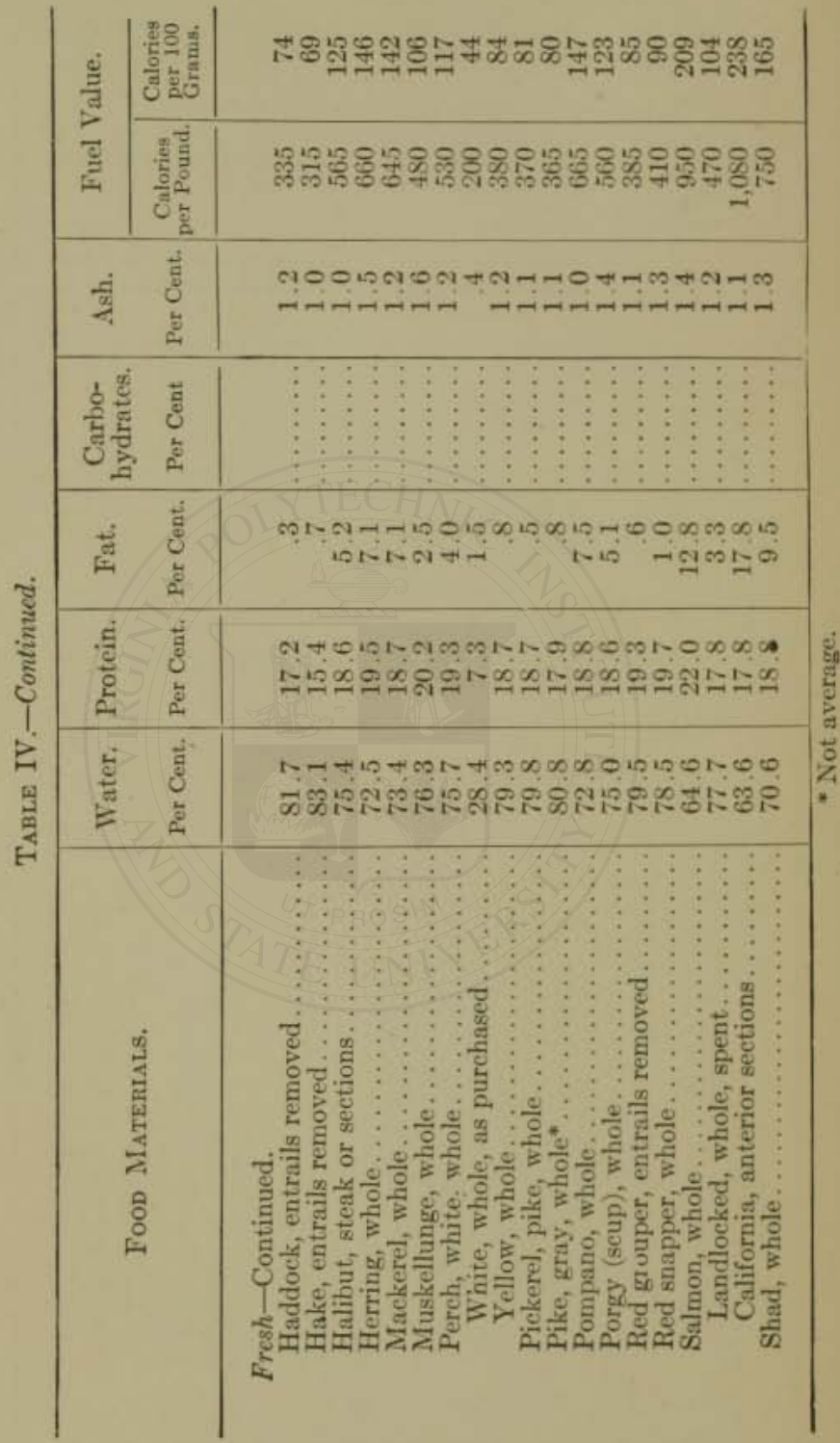




\section{COMPOSITION OF AMERICAN FOODS $\mathbf{7 5}$}

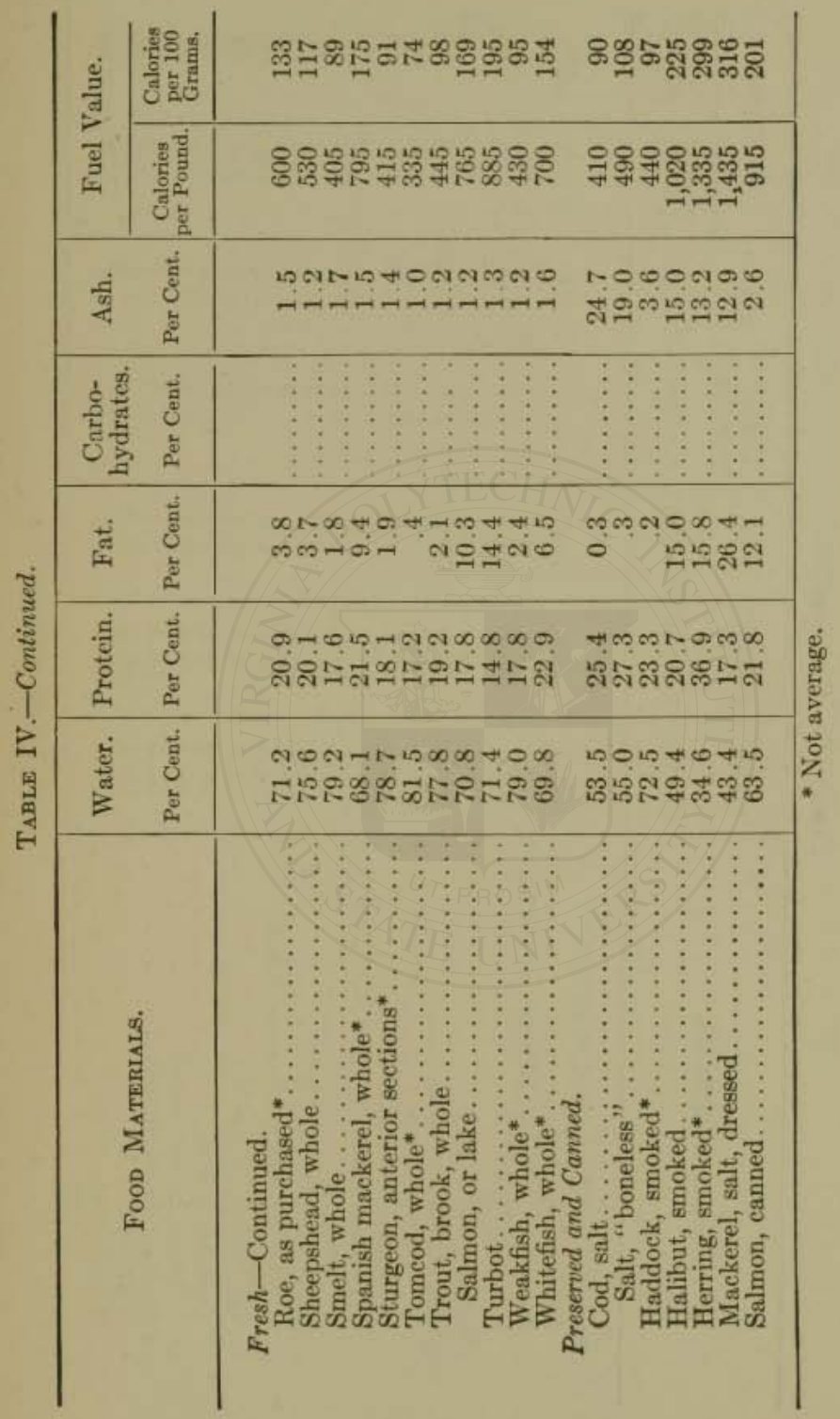




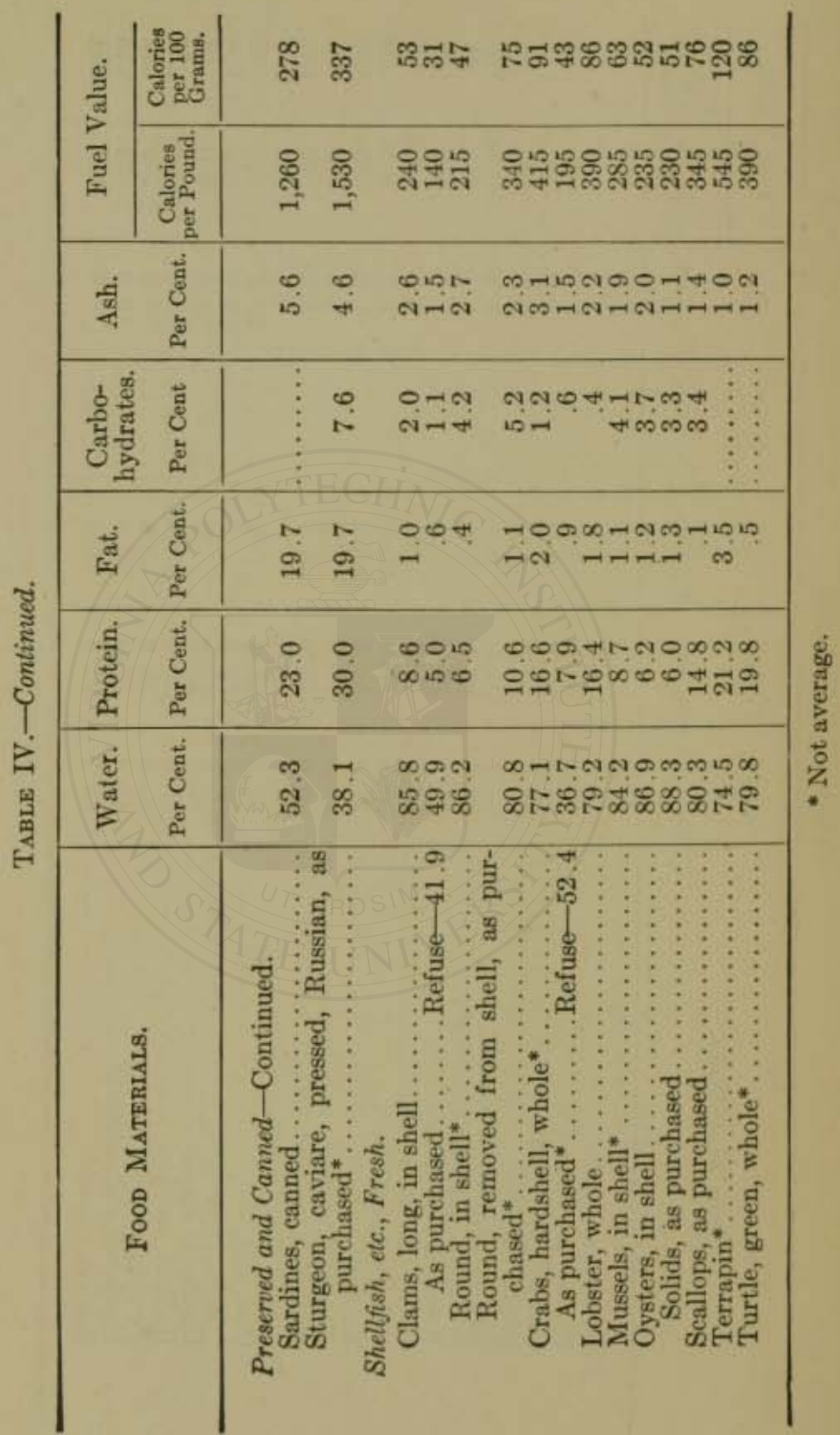


COMPOSITION OF AMERICAN FOODS

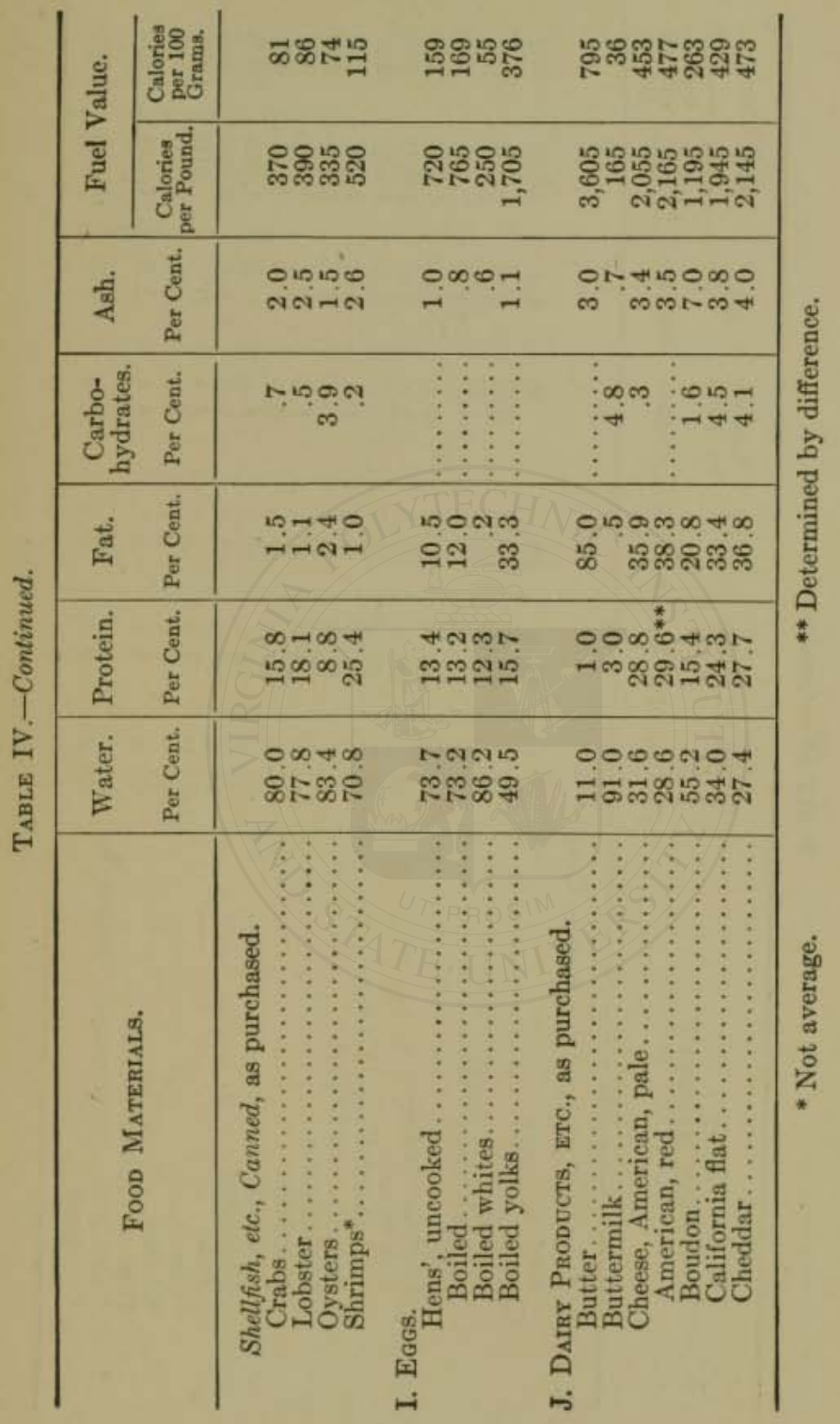




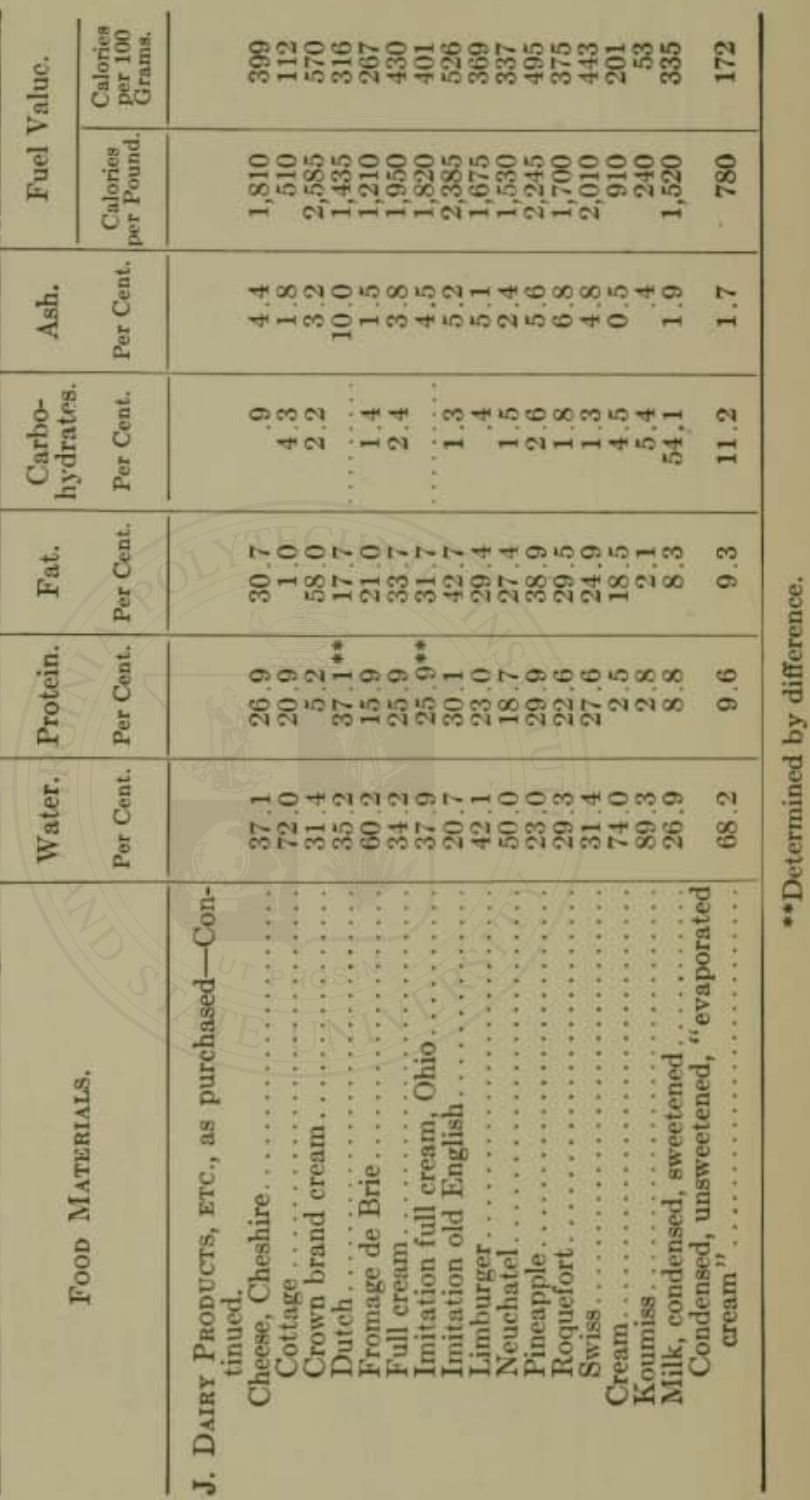


COMPOSITION OF AMERICAN FOODS 79

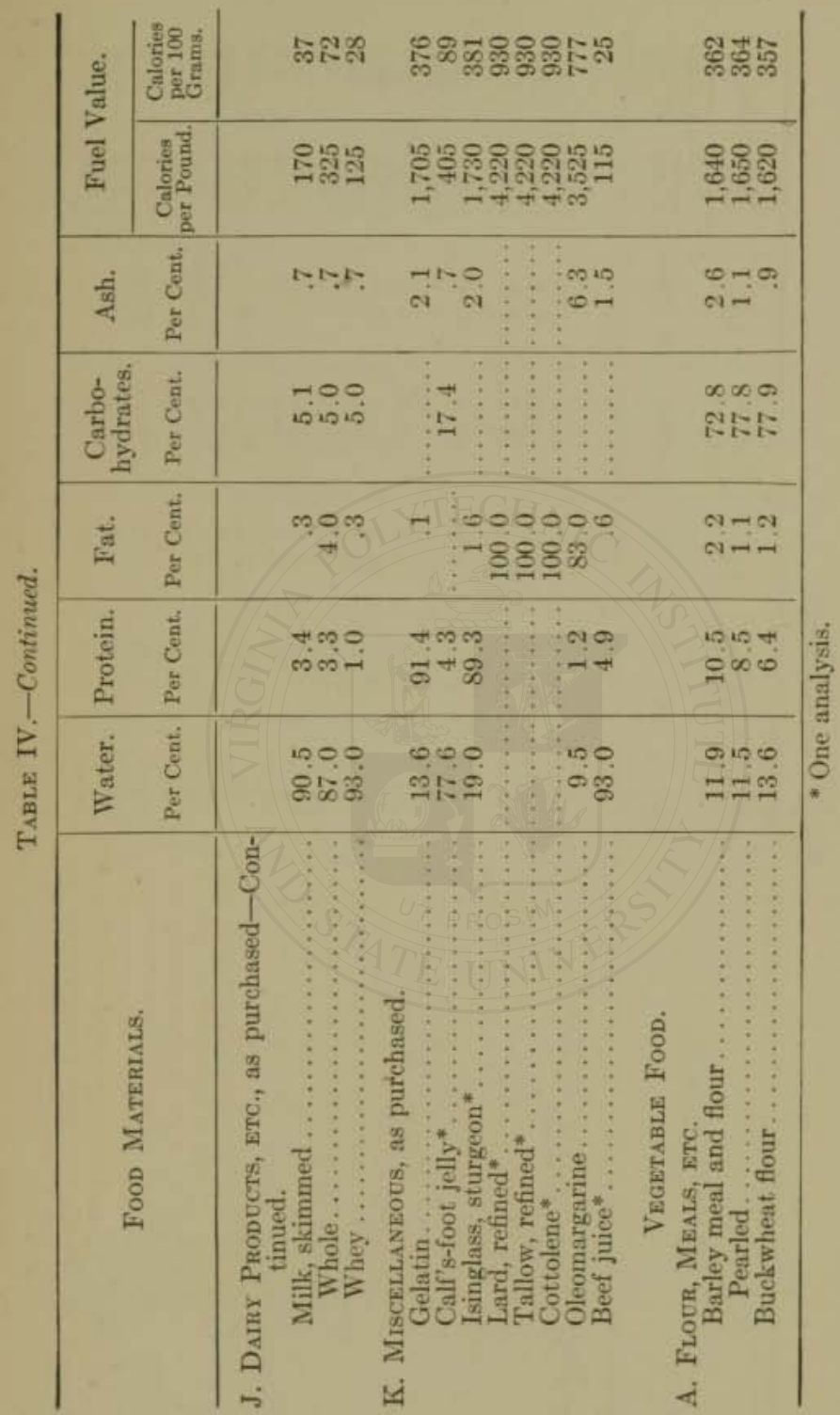




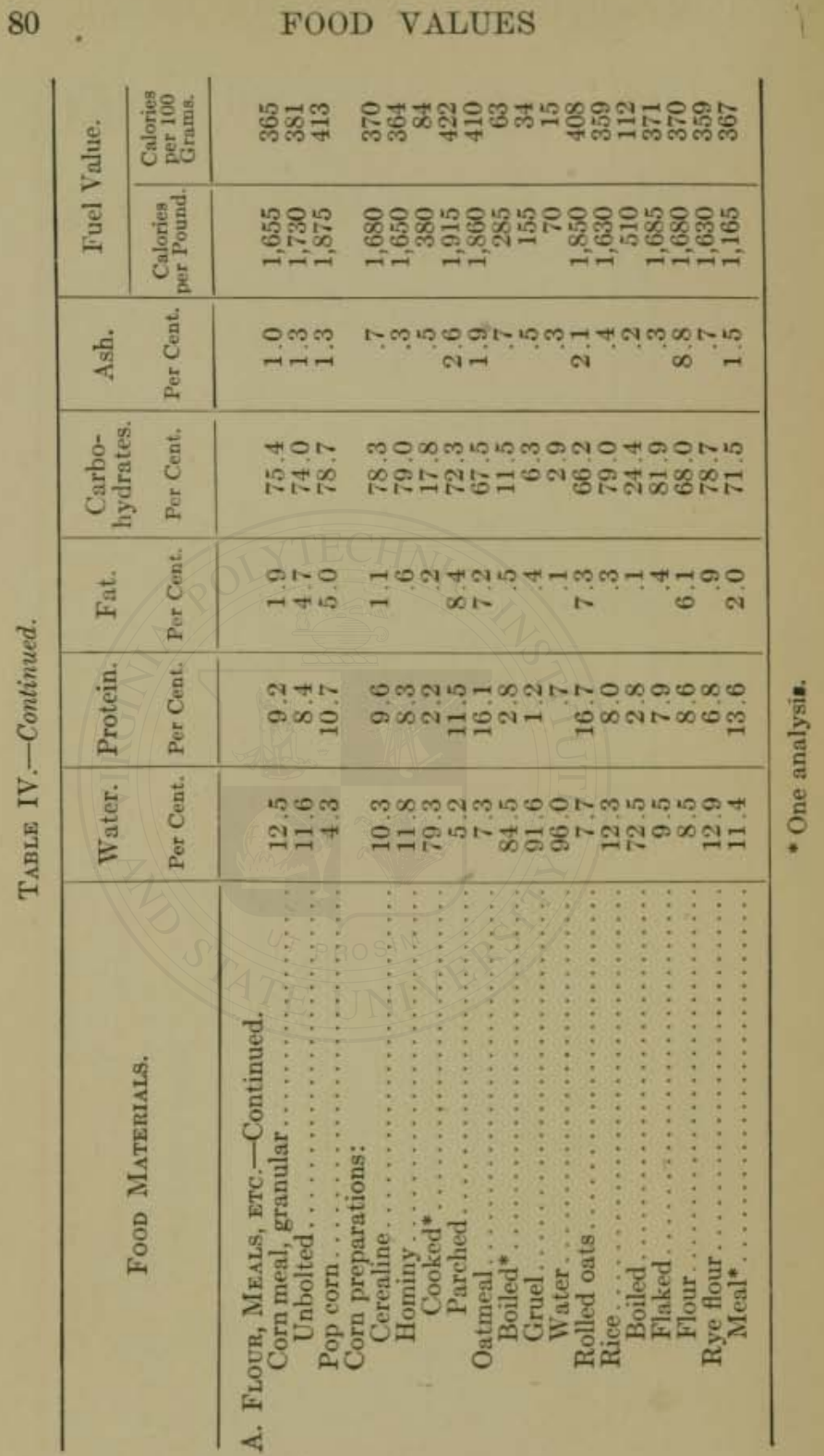


COMPOSITION OF AMERICAN FOODS 81

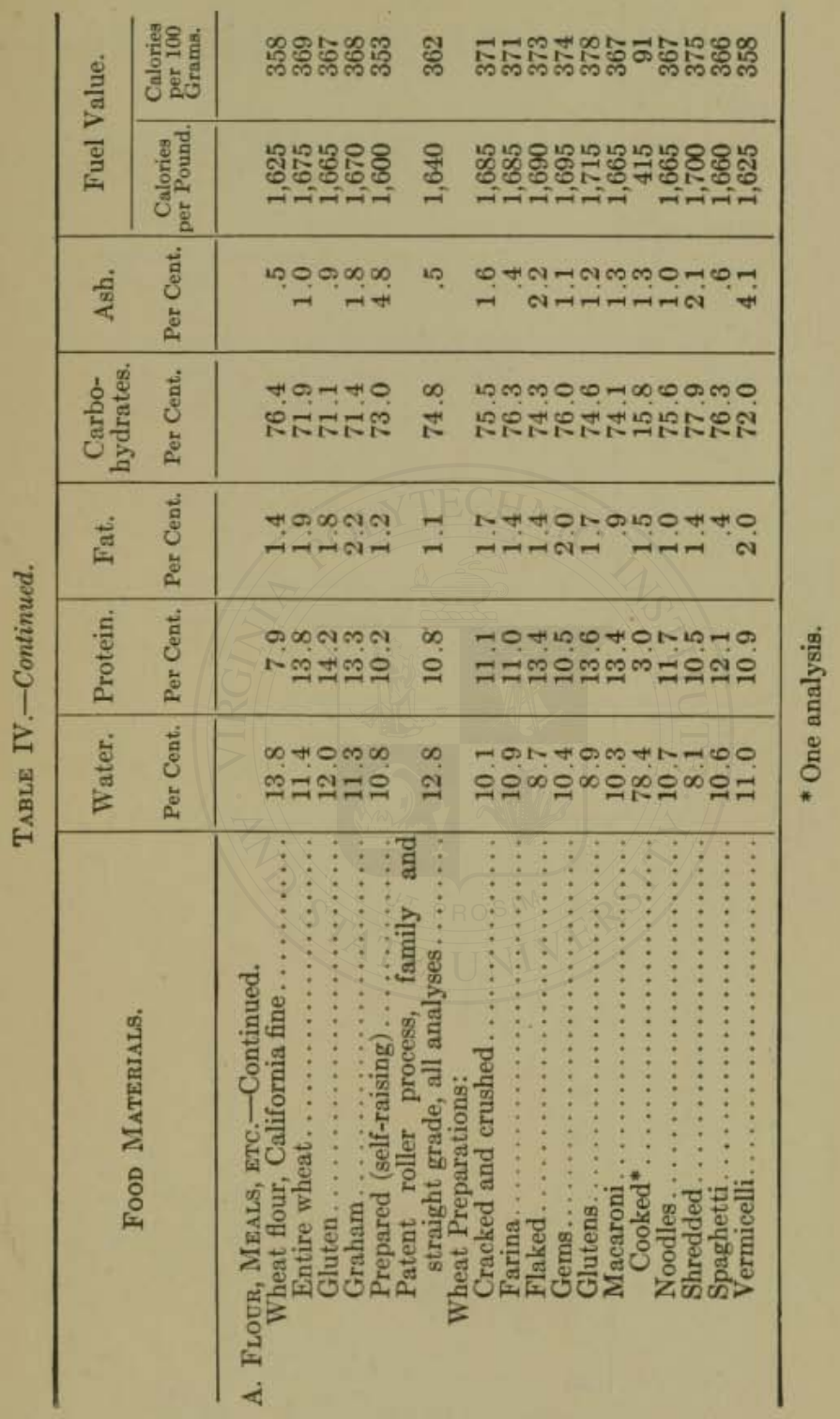




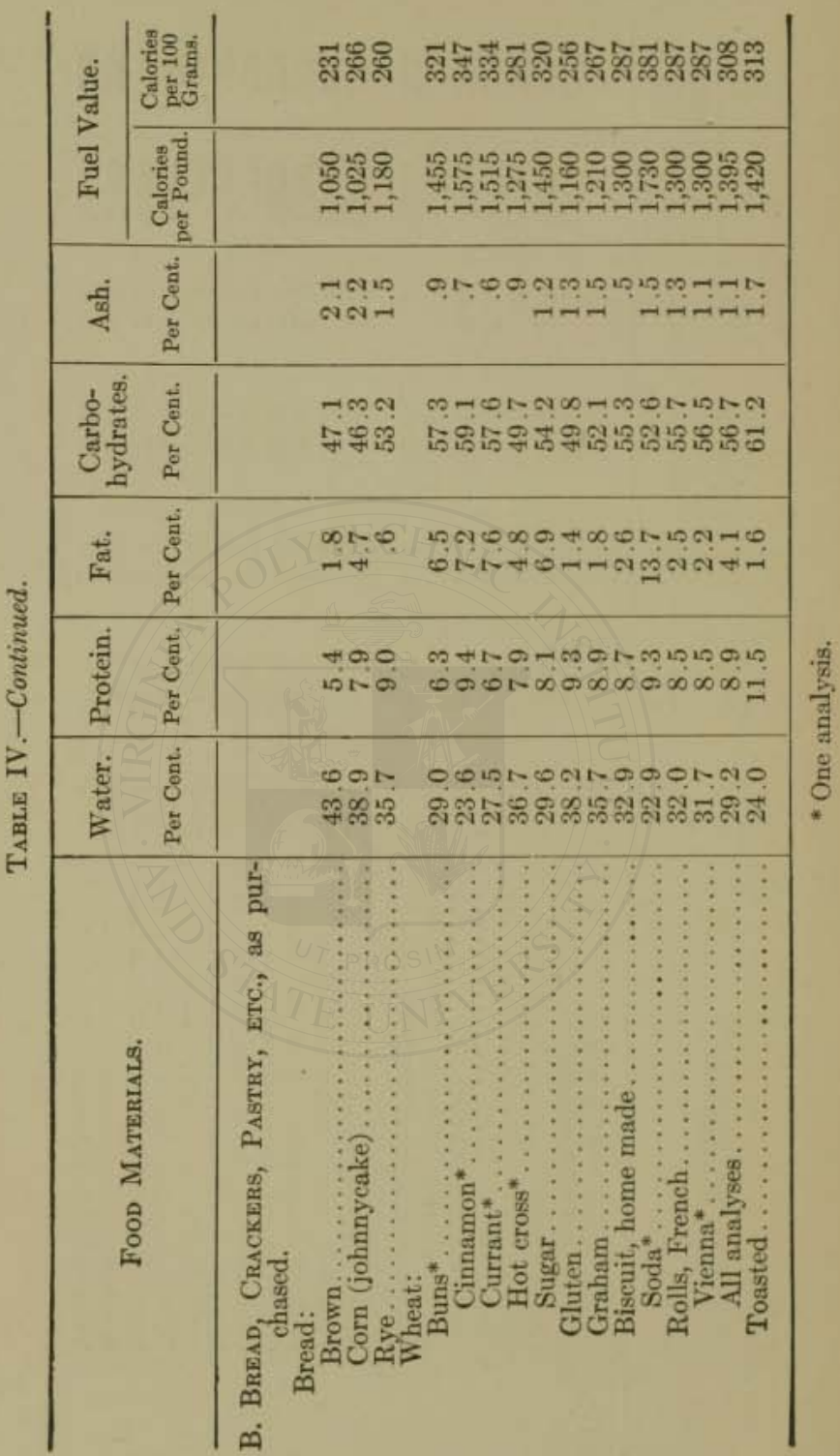


COMPOSITION OF AMERICAN FOODS 83

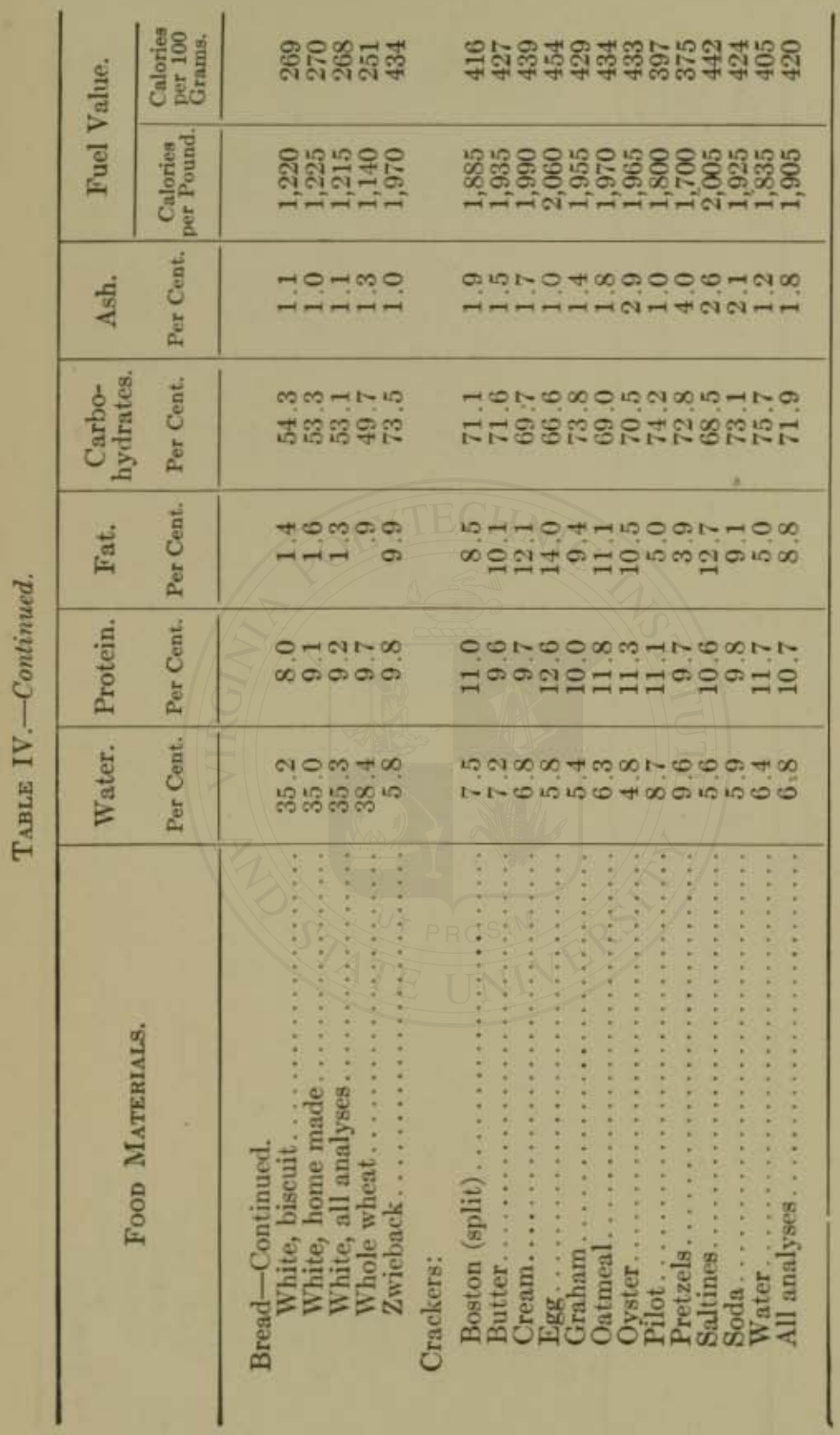




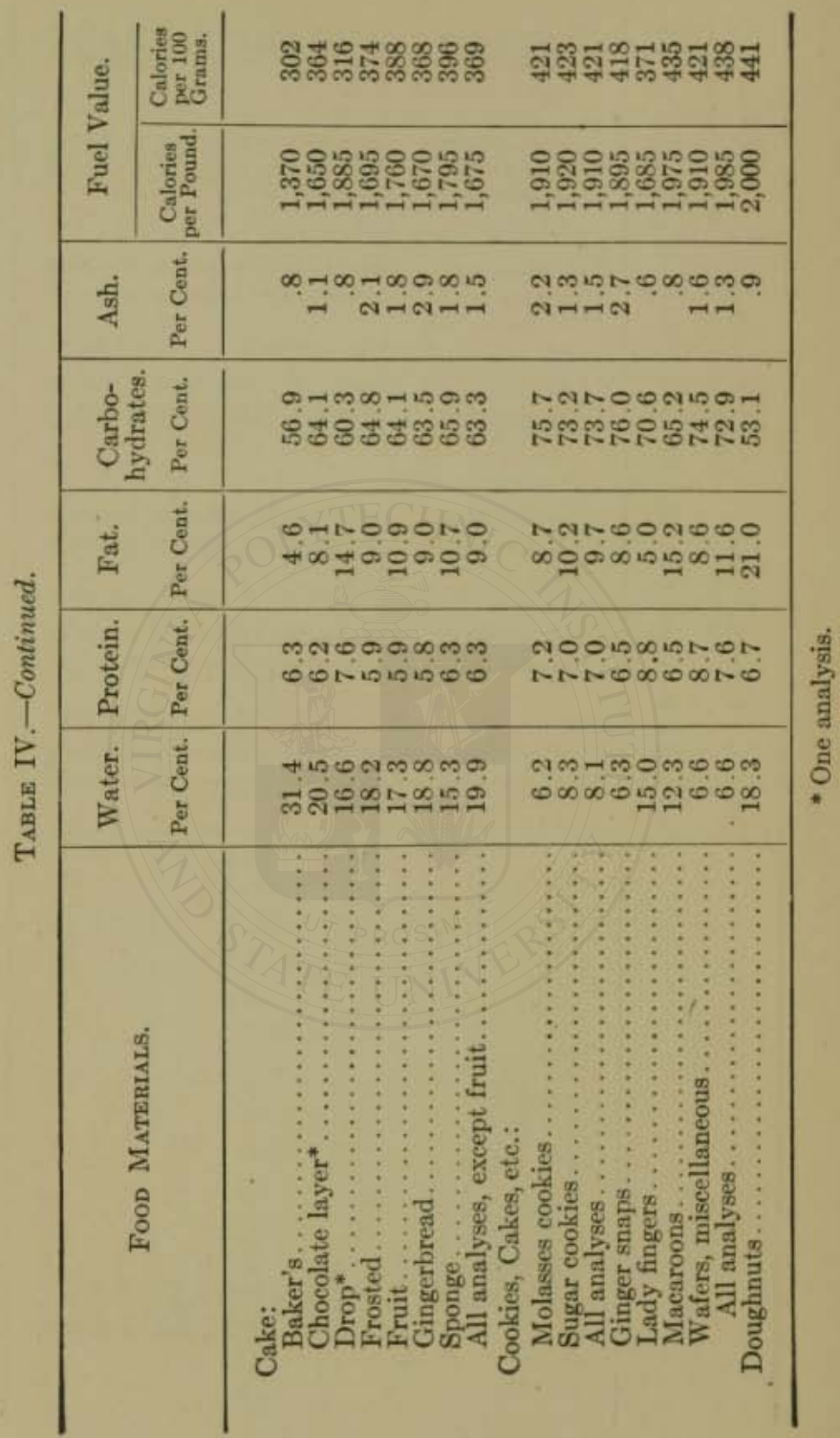


COMPOSITION OF AMERICAN FOODS 85

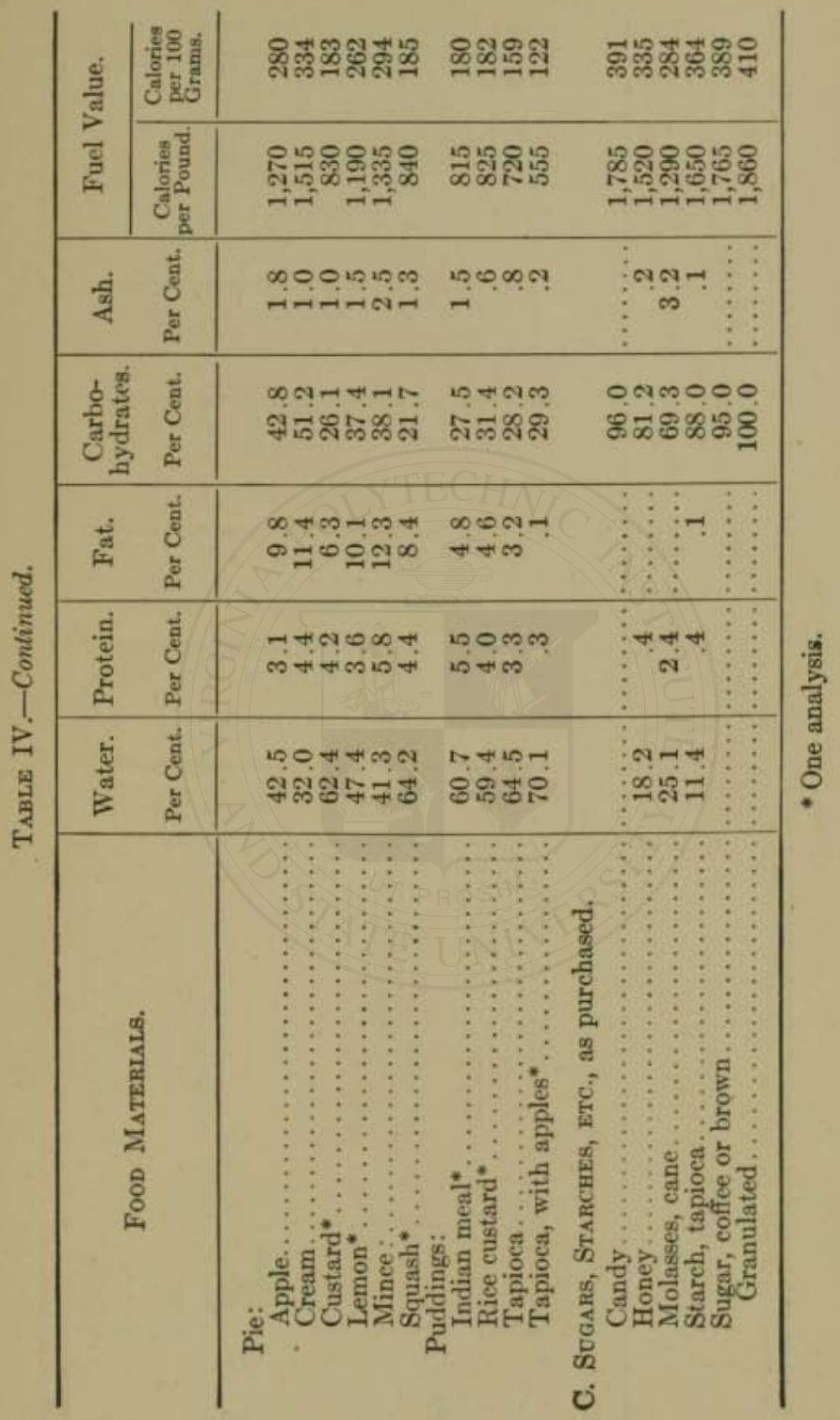




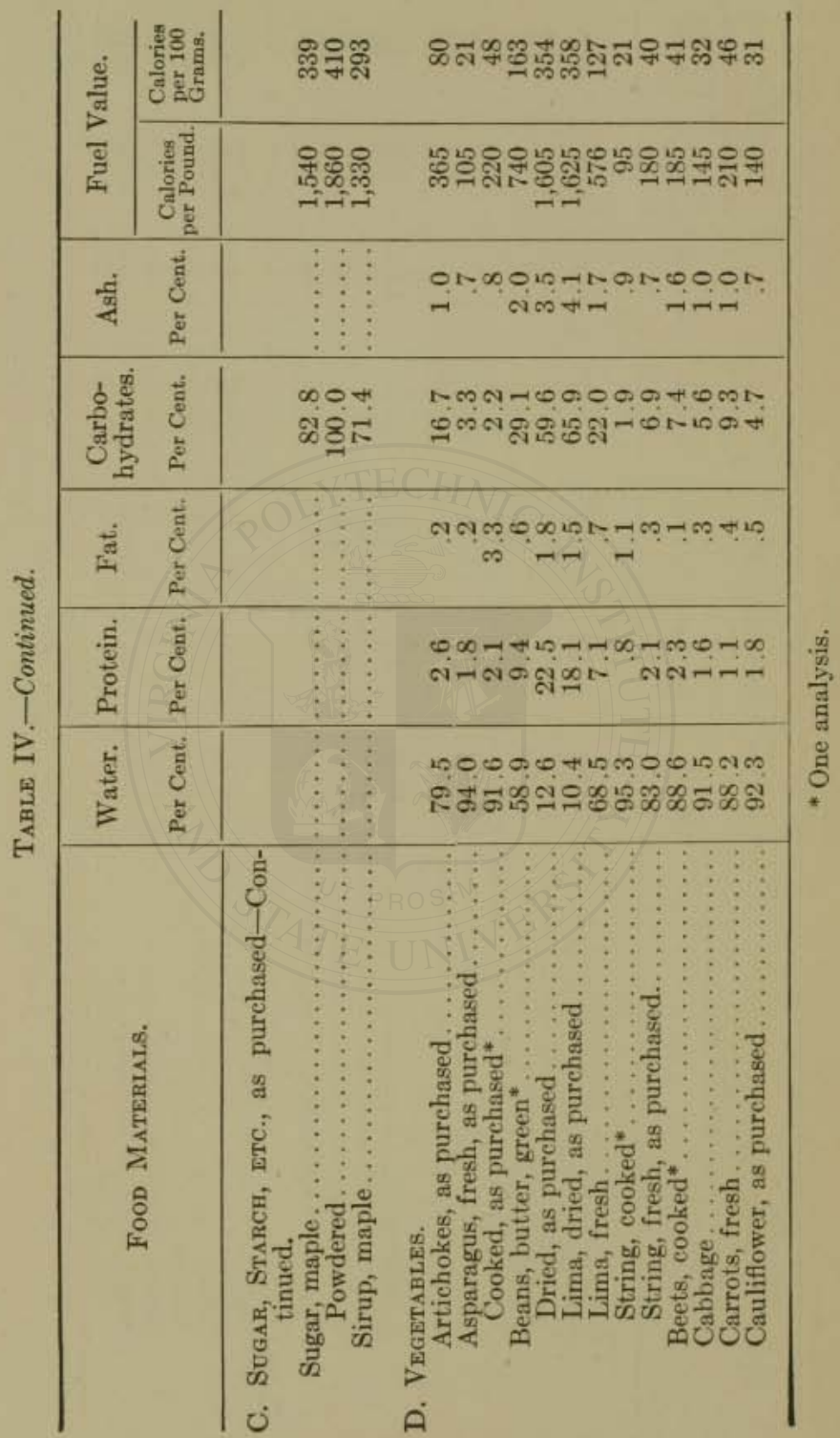


COMPOSITION OF AMERICAN FOODS 87

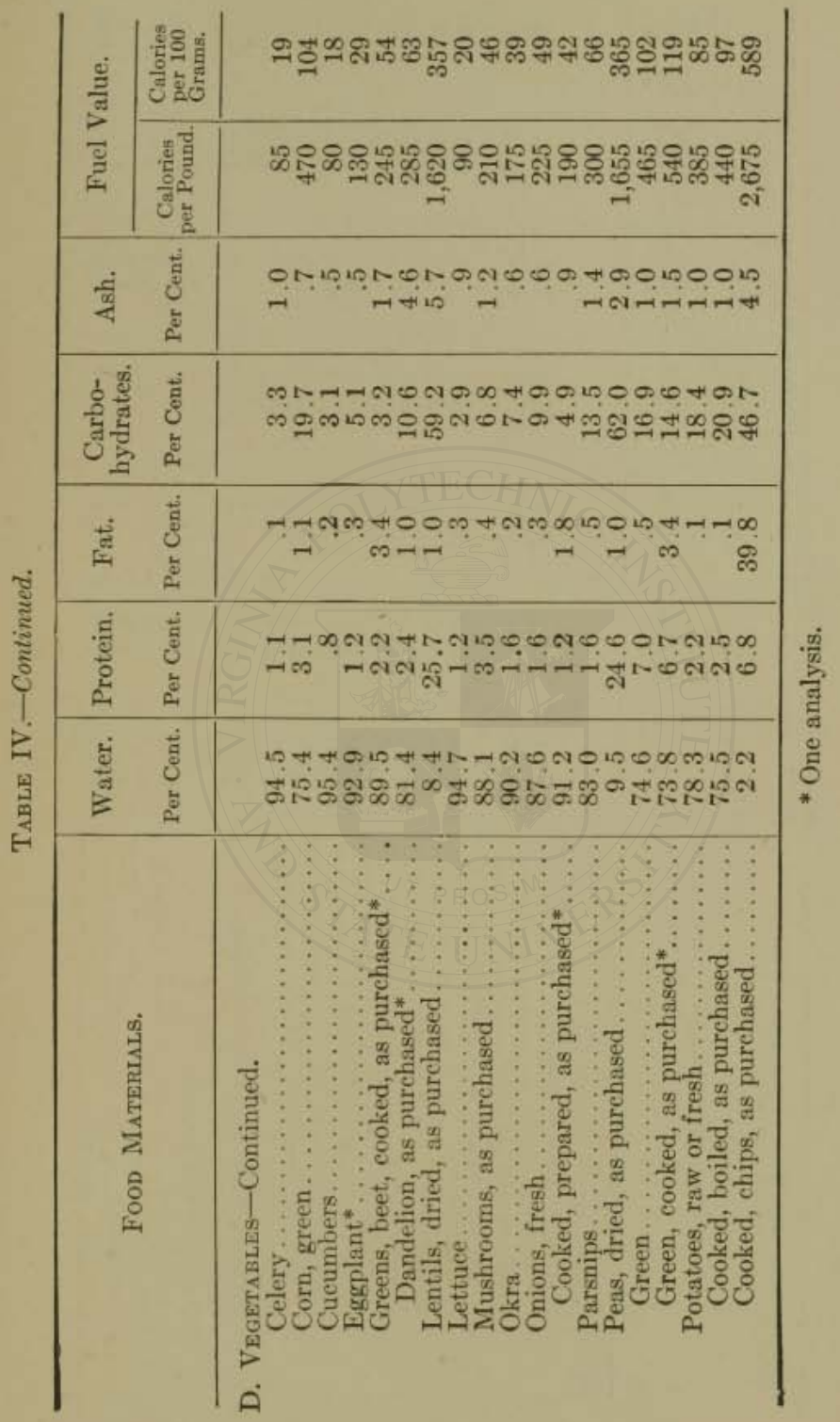




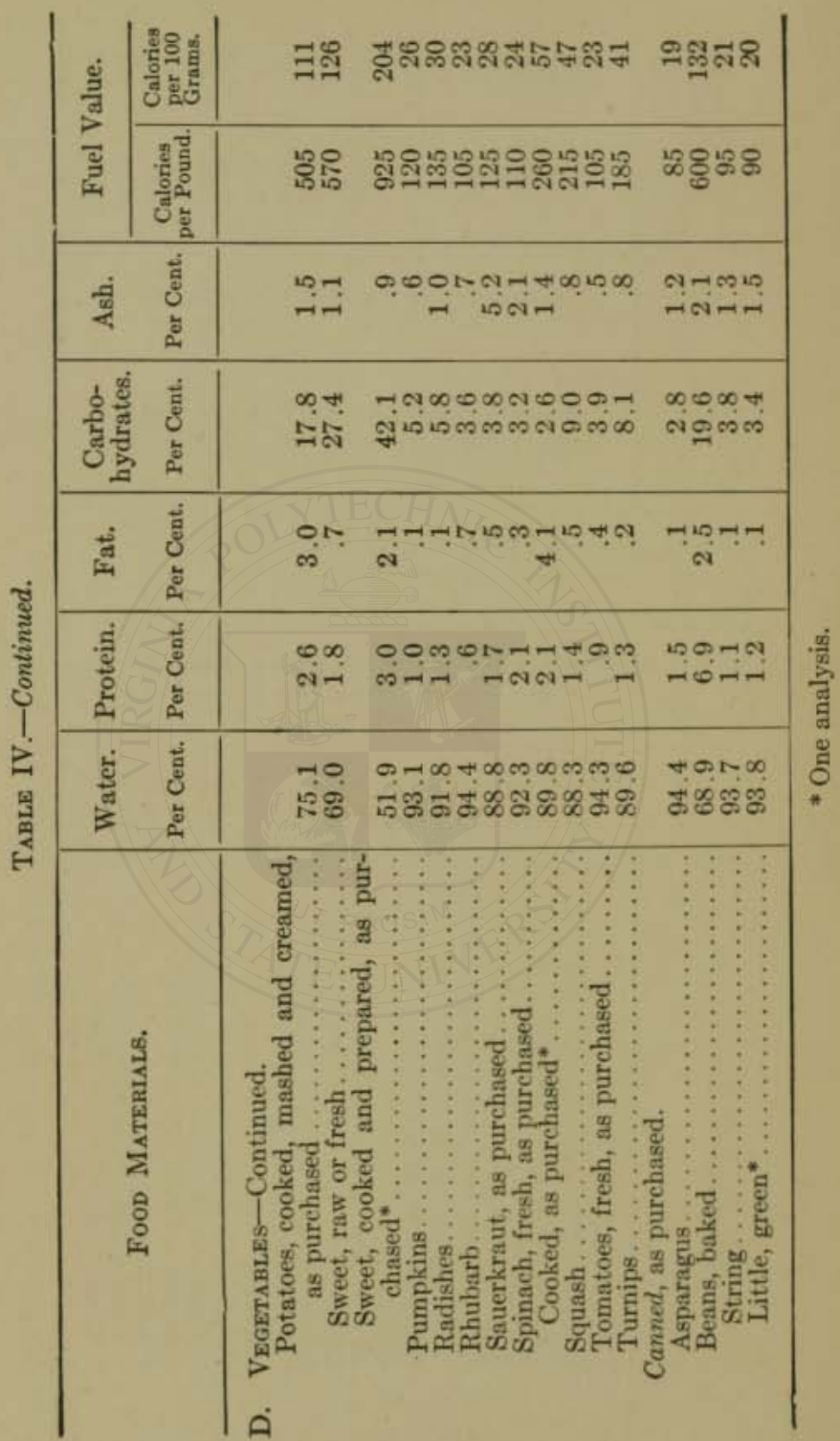


COMPOSITION OF AMERICAN FOODS 89

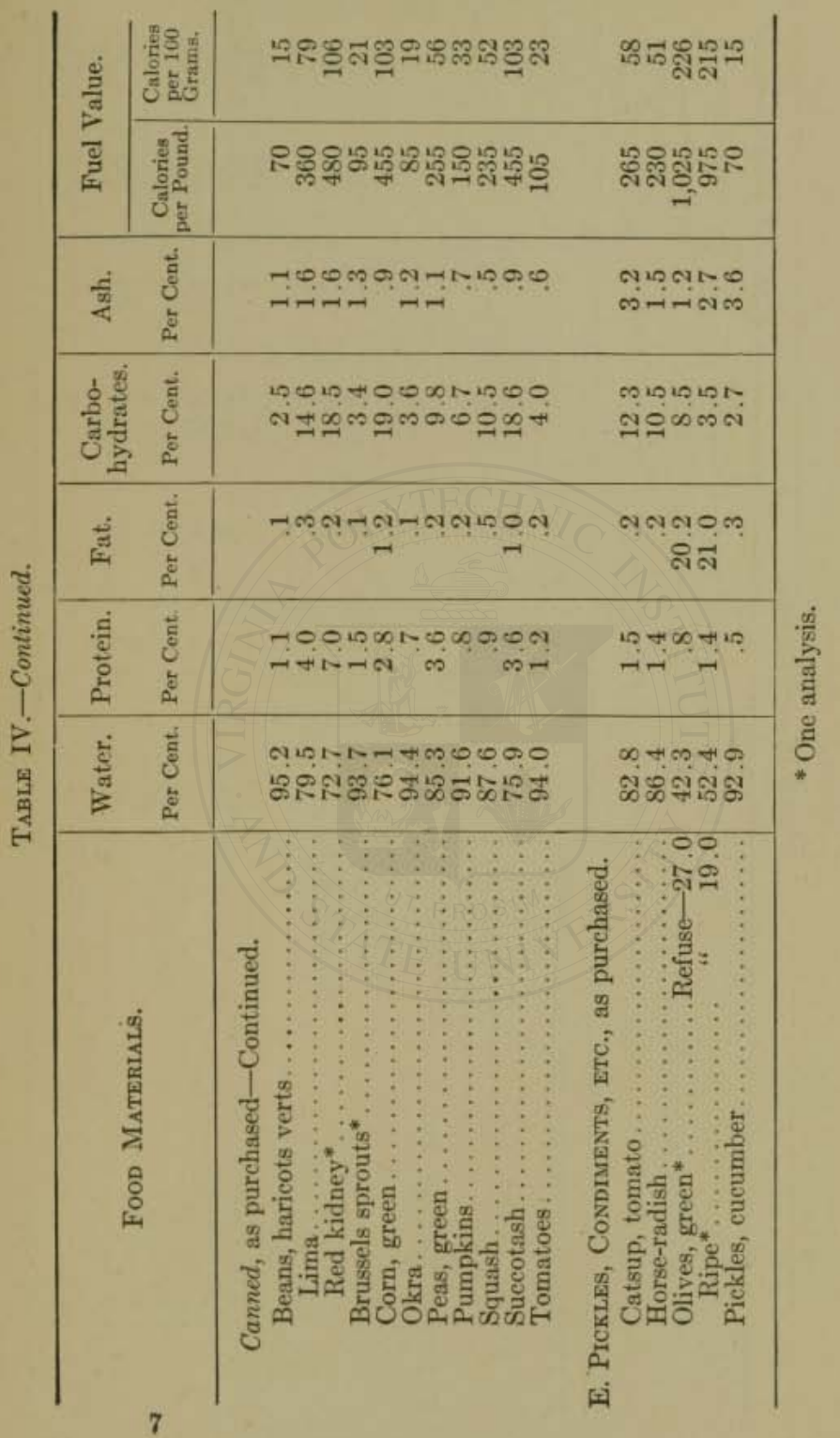




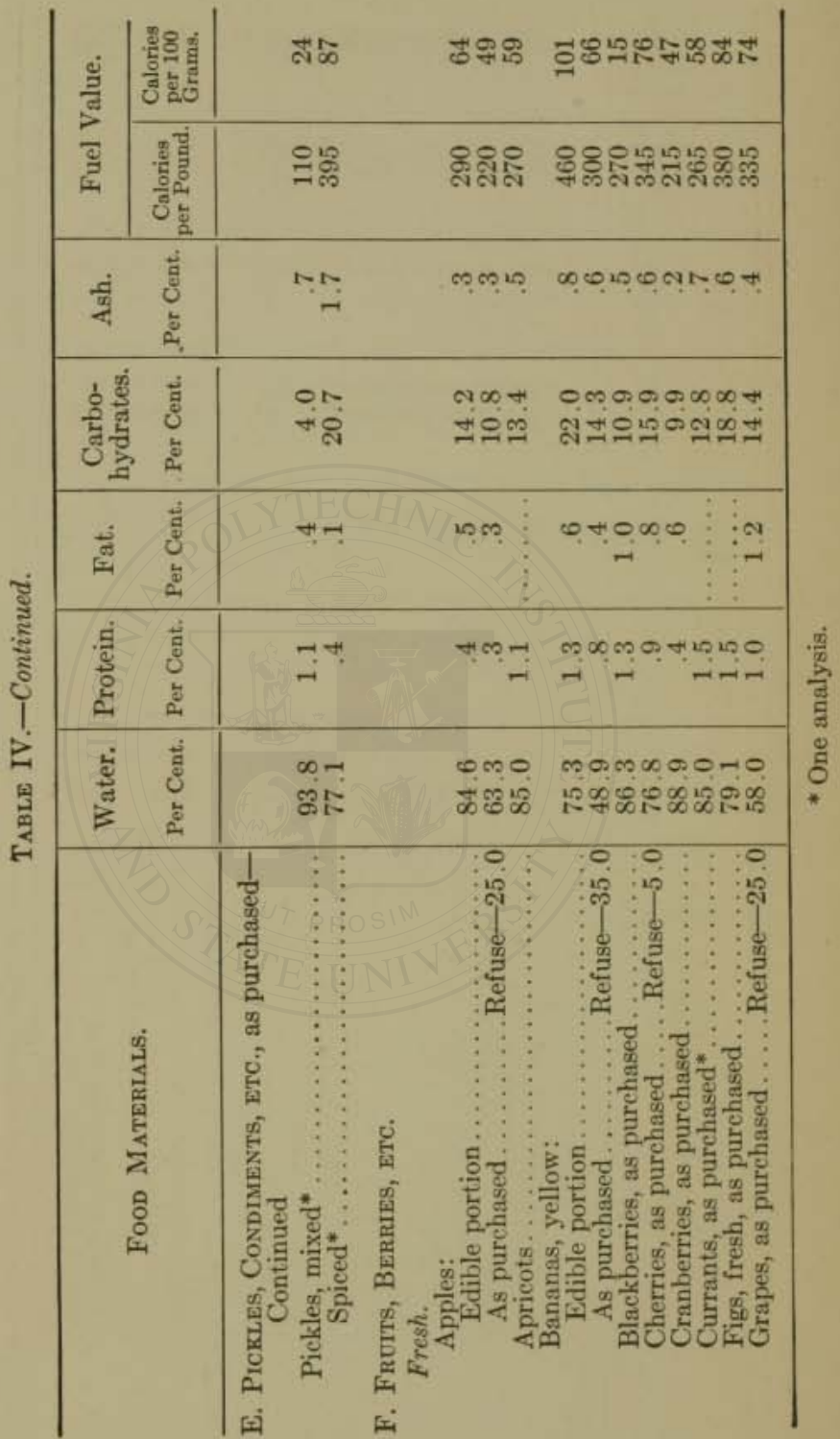


COMPOSITION OF AMERICAN FOODS 91

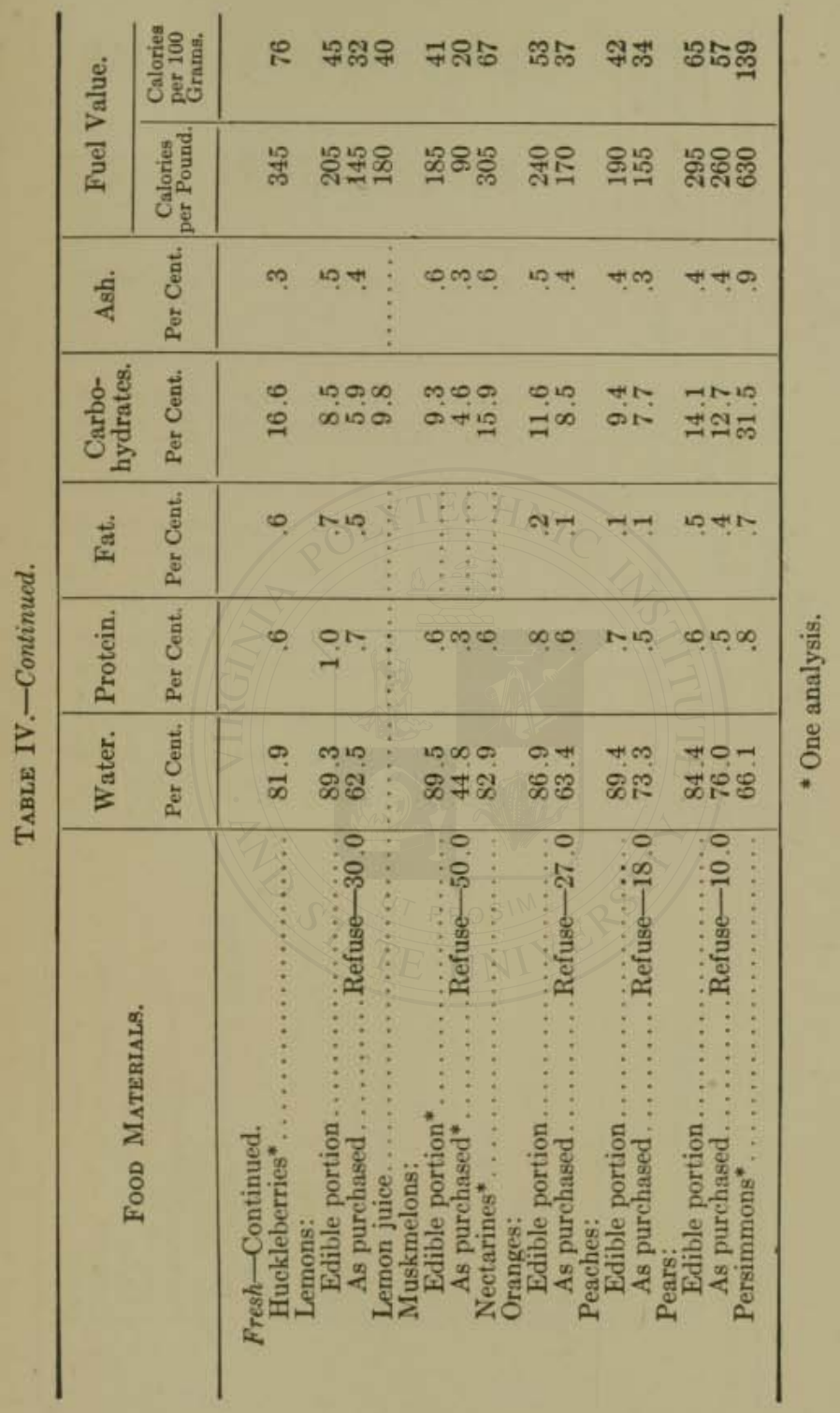


COMPOSITION OF AMERICAN FOODS 93

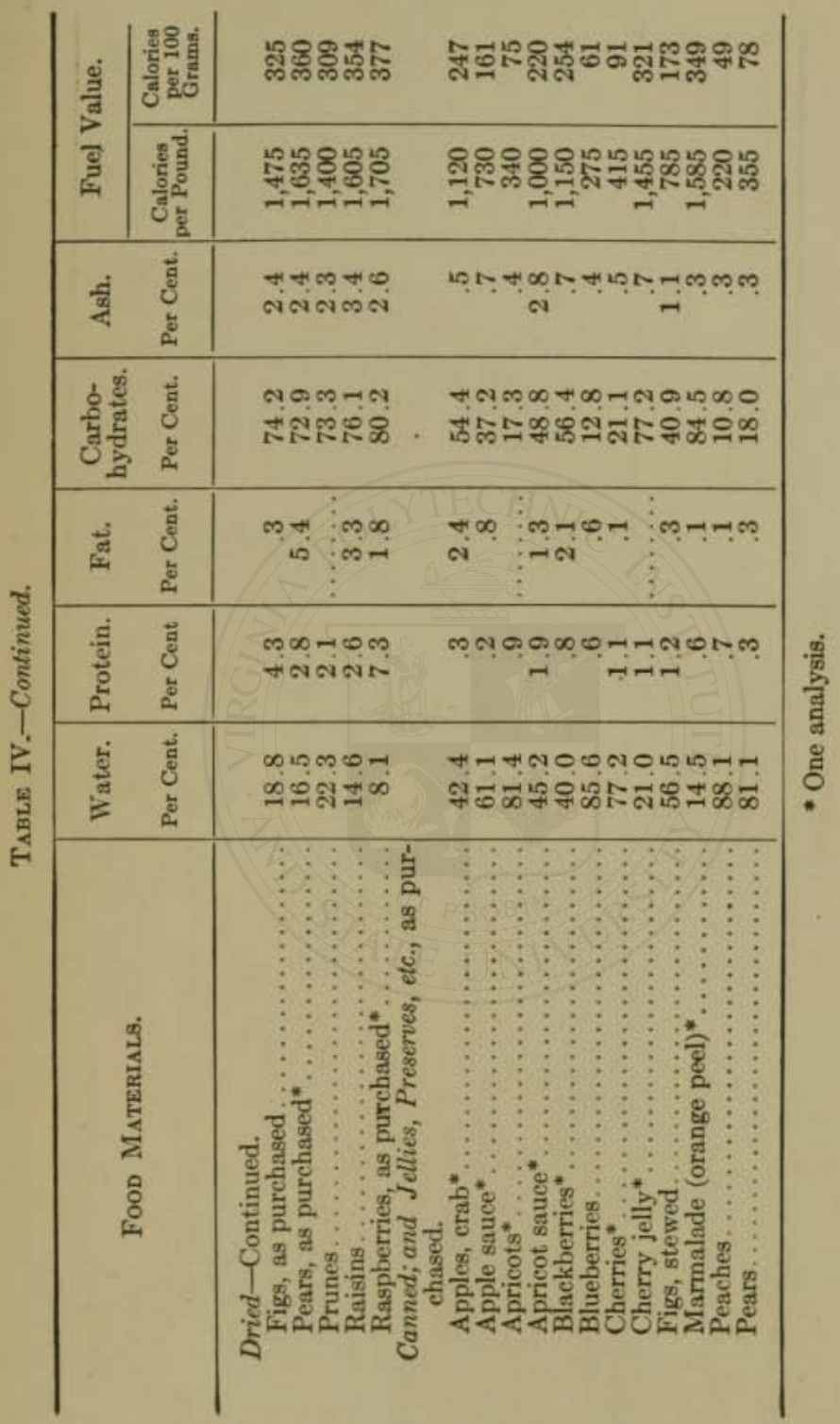


FOOD VALUES

\begin{tabular}{|c|c|c|c|c|c|}
\hline$\stackrel{\text { gี }}{3}$ & 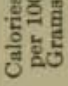 & 맴유유 & 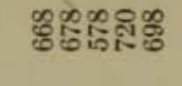 & సี่ั\% & क्ञ⿰氵 \\
\hline$\stackrel{\Xi}{\Xi}$ & 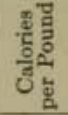 & 두웡ㅇㅇㅇ & 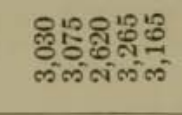 & 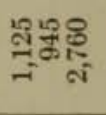 & ำเ \\
\hline दूं & 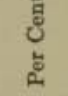 & R M & 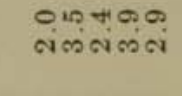 & $\begin{array}{l}9-1 \\
-i-1\end{array}$ & $\stackrel{0}{-\infty}$ \\
\hline 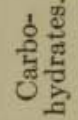 & 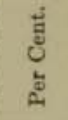 & 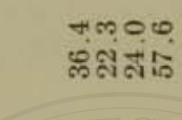 & 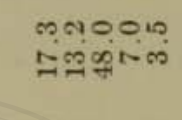 & 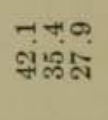 & 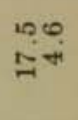 \\
\hline हैं & 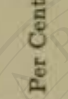 & $\begin{array}{c}n-7 \\
\vdots\end{array}$ & 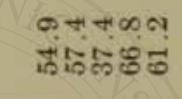 & $\begin{array}{l}+100 \\
10+8\end{array}$ & $\stackrel{m}{\infty}$ \\
\hline$\frac{\text { ज़ }}{0}$ & $\begin{array}{l}\text { हैं } \\
0 \\
\text { aें }\end{array}$ & t!? & $\begin{array}{l}00-00 \\
\text { ลี }\end{array}$ & $\begin{array}{l}\text { Nont } \\
\text { ois is }\end{array}$ & $\oplus^{\circ}$ \\
\hline 岁 & 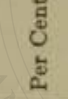 & $\begin{array}{l}\infty+\infty \theta \\
-0019\end{array}$ & 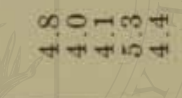 & $\begin{array}{l}0,00= \\
\sin =\end{array}$ & $\cos$ \\
\hline$\frac{5}{2}$ & & 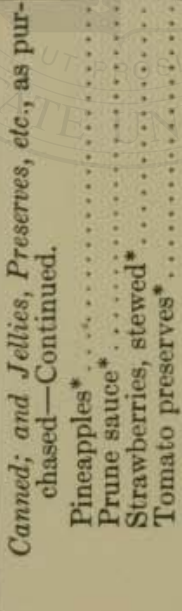 & 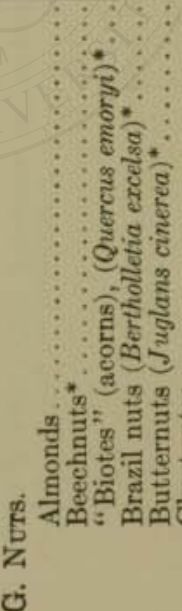 & 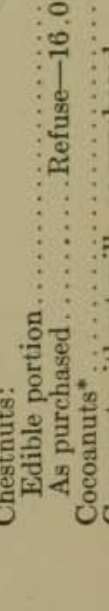 & 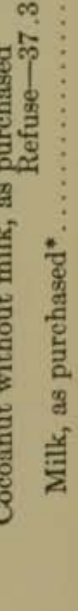 \\
\hline
\end{tabular}


COMPOSITION OF AMERICAN FOODS 95

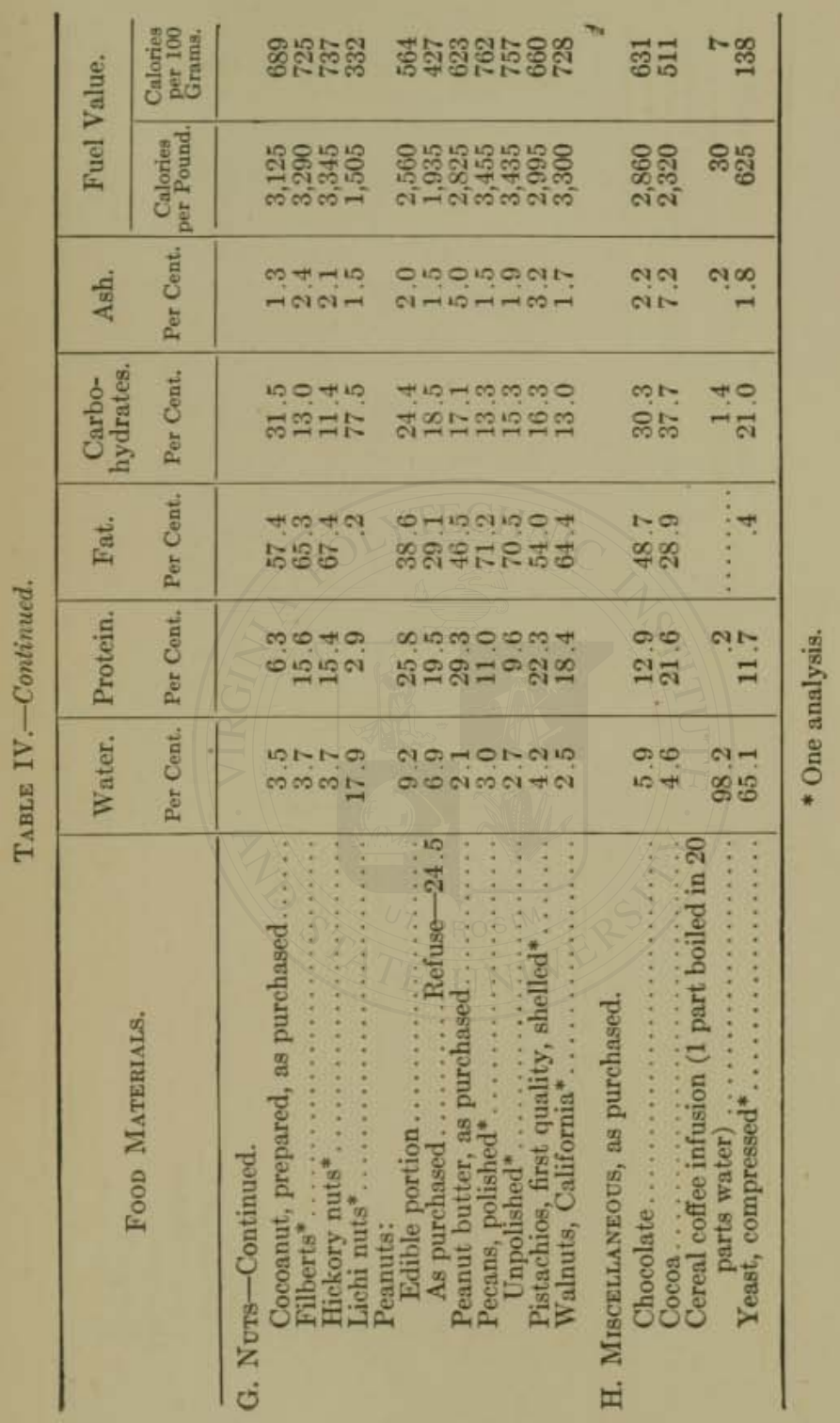




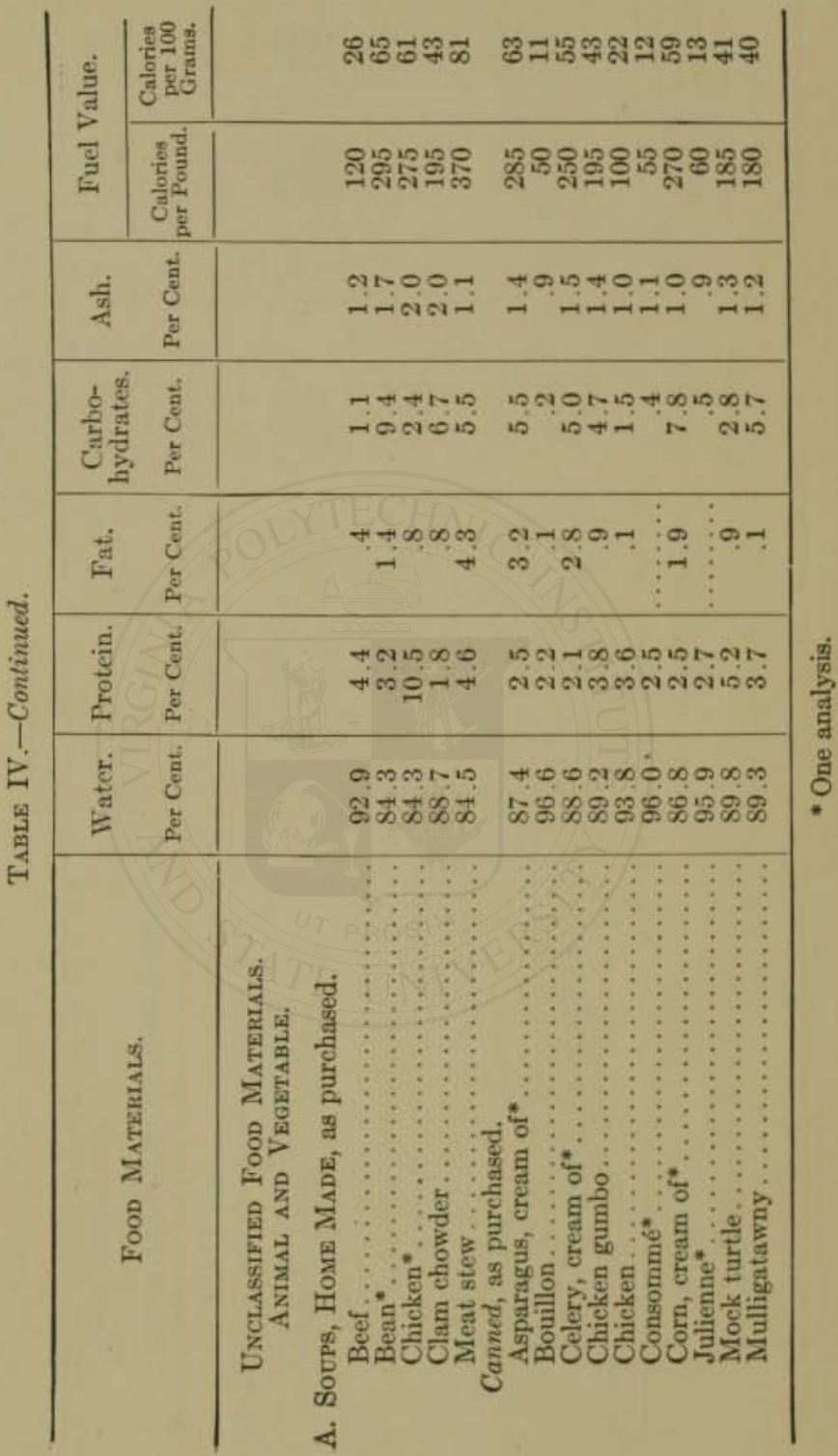




\section{COMPOSITION OF AMERICAN FOODS $\mathbf{9 7}$}

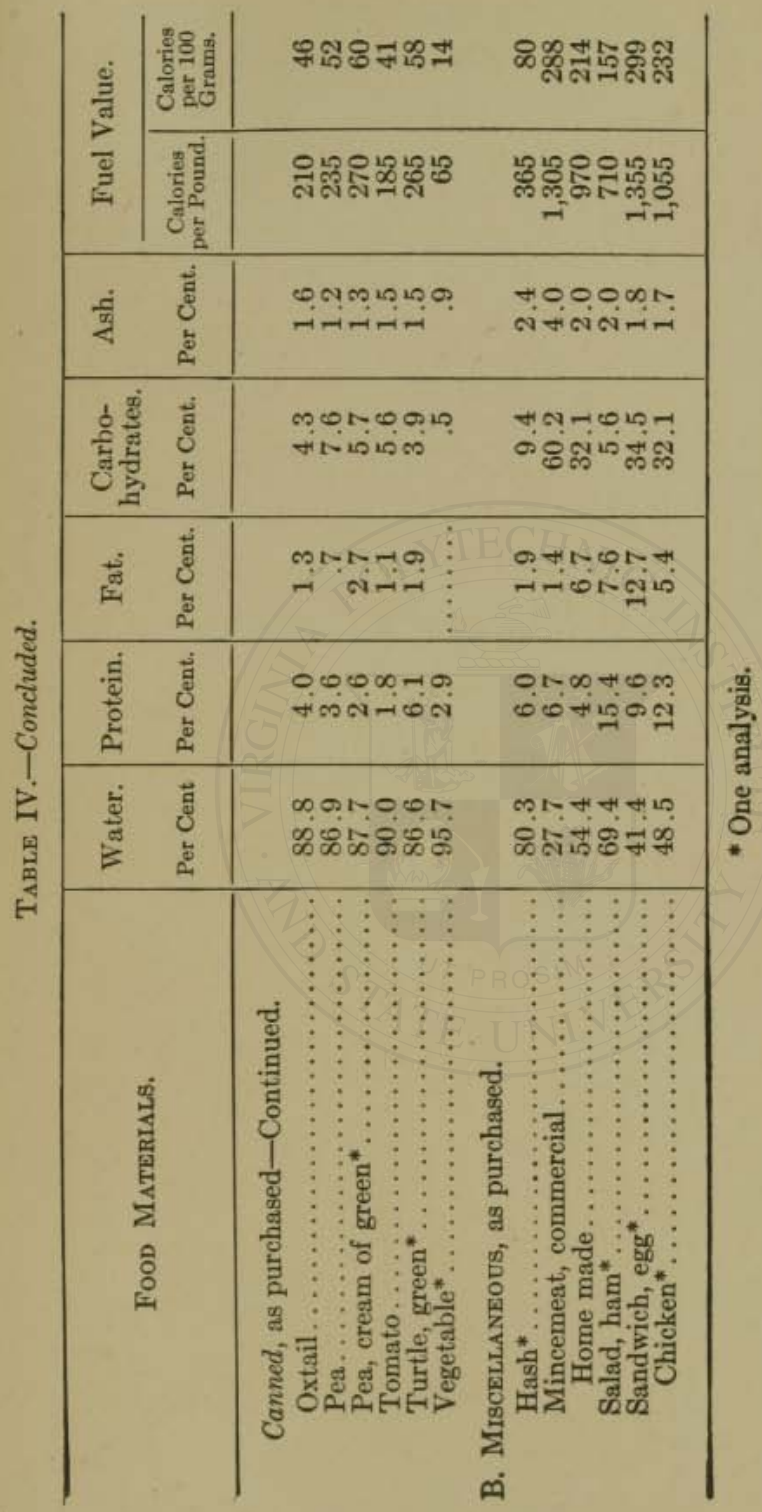




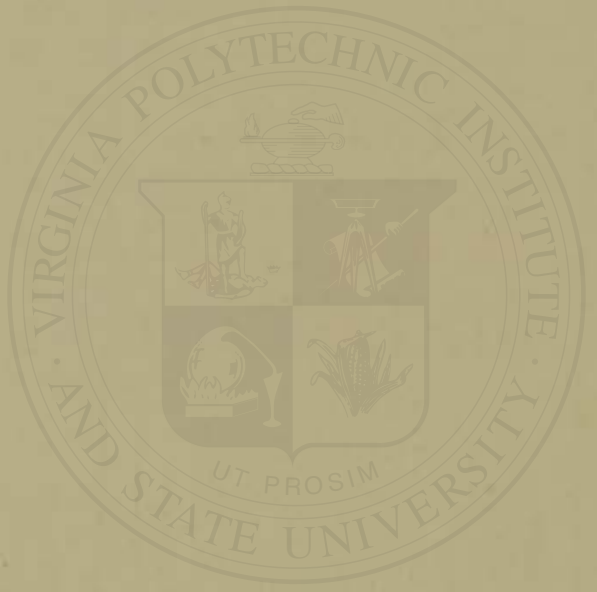




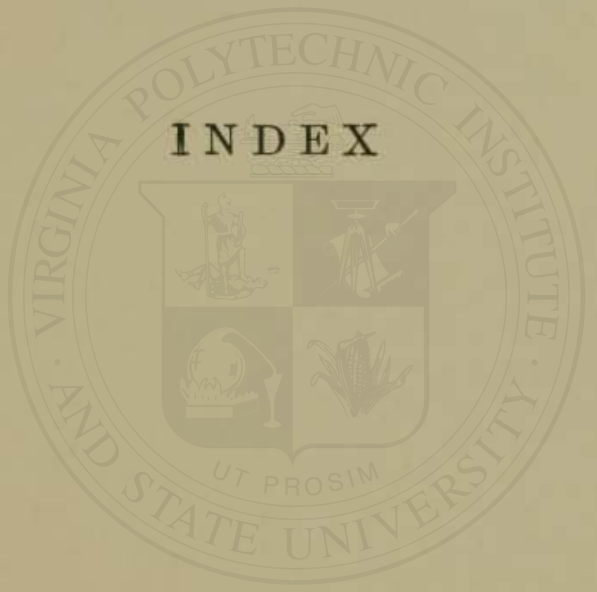





\section{IN DE X}

Abbreviations, table of, 24. Acorns, 94.

Alcohol, food value of, 4.

Alcoholic beverages, 58, 59, 60, 61.

Ale, 61 .

Almonds, 53, 94.

American fermented cider, 60.

American malt liquors, 61.

American sweet cider, 60.

American wines, 59.

Apple pie, 42, 85.

Apple sauce, 37, 93 .

Apple tapioea pudding, 46, 85.

Apples, 36, 90.

baked, 37 .

dried, 92.

Apricot sauce, 37, 93.

Apricots, 90.

eanned, 93.

dried, 37, 92.

Arrowroot gruel, 40.

Artichokes, French, 86. cooked, 34.

"As purchased," 28.

Ash, 1, 12.

Asparagus, 86.

eanned, $34,88$.

cooked, 86 .

cream of, soup, canned, 31, 96.

Availability, 7 .
Bacon, smoked, 69.

Baked beans, eanned, 34,88 . homemade, 34 .

Baked custard, 44.

Baker's cake, 84.

Bananas, 36, 90.

baked in skin, 46 . peeled, 46.

Barley, pearled, 79.

Barley gruel, 40.

Barley meal and flour, 79 .

Bass, black, 73.

sea, 73.

striped, 73.

Bean soup, homemade, 30, 96.

Beans, 34, 86.

butter, green, 86 .

dried, 86.

haricot verts, 89 .

little green, eanned, 88 .

red kidney, eanned, 34, 88.

string, canned, 28.

cooked, $34,86$.

fresh, 86 .

Beechnuts, 94.

Beef, 26, 27, 63, 64, 65.

boiled, canned, 65 .

brains, 64 .

brisket, 63 .

corned, 65.

eanned, 65 .

chuck, 63 . 
Beef, cooked, 26, 27, 64. corned and pickled, 65. canned, 26, 65.

dried, salted and smoked, 65. flank, 63.

corned, 65.

fore quarter, 64 . shank, 64.

fresh, 63,64 .

heart, 64 .

hind quarter, 64 .

kidney, 64.

liver, 64 .

loin, 63.

luncheon, 65 .

mess, 65 .

organs, 64 .

plate, corned, 65 .

porterhouse steak, 63.

pressed, 64 .

ribs, 63.

roast, $26,64,65$.

very lean, 26.

round, 63.

round steak, cooked, 64 .

rump, 63.

corned, 65.

sandwich meat, 64 .

scraps, cooked, 64.

shoulder and clod, 64 .

sirloin butt, 63 .

sirloin steak, 63 .

spiced, 65.

suet, 64 .

sweetbreads, 64 .

tenderloin, 63.

broiled, 64 .

tongue, 64 .

canned, 27, 65 .

pickled, 65.

Beef juice, 26, 79.

Beef soup, home made, 30, 96 .
Beer, 61.

Beet greens, cooked, 34, 87 .

Beets, cooked, 34, 86 .

Benedictine, 59.

Berries, 36, 90, 91, 92.

Biscuits, 82.

home made, 38,82 .

Blackberries, 36, 90.

canned, 93.

Blackfish, 73 .

Blane mange, 47.

Blueberries, canned, 93.

Bluefish, 73. cooked, 29.

Bock beer, 61 .

Boston crackers, 39,83 .

Bouillon, canned, 30, 96 .

Brandy, California, 58.

cherry, 58.

cognac, 58.

Brazil nuts, 53, 94.

Bread, 38, 82, 83.

Bread pudding, 43 .

Breakfast foods, 40 .

Brown bread, baker's, 38, 82.

Brussels sprouts, eanned, 89.

Buckwheat flour, 79.

Buns, cinnamon, 38, 82.

currant, 38,82 .

hot eross, 82 .

sugar, 82.

Butter, 31, 77.

Butter beans, cooked, 34 .

Butter erackers, 39, 83.

Butterfish, 73.

Buttermilk, 33, 77.

Butternuts, 94.

Cabbage, 86.

cooked, 34 .

Calf's-foot jelly, 28, 79.

California red wine, 59. 
California white wine, 59.

Calorie, 5.

Cake, 42, 84.

Candy, 85.

Canned soups, 97.

Cantaloupe, 36 .

Capon, 27, 70.

Caramel sauce, 50.

Carbohydrates, 1, 2.

Carrots, 86. cooked, 34.

Catawba sweet wine, 59.

Catsup, tomato, 51, 89.

Cauliflower, 86. cooked, 34.

Caviare, 29, 76.

Celery, 34, 87 . cream of, soup, $31,96$.

creamed, 34 .

Cereal coffee, 95.

Cerealine, 80.

Champagne, 59, 60.

Chartreuse, 59.

Chaud eau sauce, 51.

Cheese, 32, 77, 78 .

American pale, 32, 77 .

American red, 77 .

Boudon, 77.

California flat, 77 .

Camembert, 32.

Cheddar, 32, 77.

Cheshire, 32, 78 .

cottage, 78 .

cream, 78.

Duteh, 32.

Fromage de Brie, 32.

full-cream, 32 .

imitation full-eream, 78.

imitation old English, 78.

Limburger, 32, 78.

Neuchatel, $32,78$.

pineapple, 32,78 .
Cheese, Roquefort, 32, 78.

Stilton, 32.

Swiss, 32, 78.

Cherries, 36, 90.

eanned, 93.

Cherry jelly, 93.

Chestnuts, 53, 94.

Chicken, 27, 70.

boned, canned, 73 .

broilers, 70 .

creamed, on toast, 27.

dark meat of, 70 .

fricasseed, 27.

giblets, 70 .

gizzard, 70 .

heart, 70 .

light meat of, 70 .

liver, 70 .

potted, 73 .

roast, 27.

sandwich, eanned, 73 .

young, 70 .

Chicken gumbo, canned, 30,73 ,

96.

Chicken sandwich, $39,97$.

Chicken soup, canned, 73, 96.

homemade, $30,96$.

Chocolate, 95.

Chocolate custard, 44.

Chocolate layer eake, 42, 84 .

Chocolate pudding, 43.

Cider, 59, 60.

Citron, dried, 92.

Clam ehowder, home made, 30.

96.

Clams, long, 29, 76.

round, 29,76 .

Claret, 60.

Cocktail, 58.

Cocoa, 54, 95.

Cocoanut, 53, 94.

prepared, 95. 
Cocoanut milk, 94.

Cod, cooked, 29.

salt, 75 . boneless, 75 .

steak, 73.

whole, 73 .

\section{Coffee, 54.}

Condensed milk, 33, 78.

Condiments, 50, 51, 52, 89, 90.

Consommé, canned, $30,96$.

Cookies, 49, 50, 84 .

Cooking, loss of weight in, 17 .

Corn, canned, 34, 89.

eream of, soup, 31,96 .

green, 87 .

cooked, 34 .

preparations of, 80 .

Corn bread, 38, 82.

Cornmeal, granular, 80 . unbolted, 80 .

Cornmeal gruel, 41.

Cottolene, 79.

Crab-apple jelly, 93.

Crabs, eanned, 77 . hardshell, 30, 76.

Crackers, 39, 83.

Cranberries, 90. stewed, 37.

Cream, 32, 78. whipped, 32 .

Cream lunch crackers, 39, 83.

Cream pie, 42, 85.

Cream sauce, 51.

Cream soups, 31.

Cream toast, 40.

Creamed oysters on toast, 30 .

Creme de menthe, 59.

Cucumber, 34, 87.

Curaçao, 59.

Currant jelly, 37.

Currants, 36, 90. dried, 92.
Custard pie, 42, 85.

Custards, 44, 45.

Dairy products, $31,32,33,77$, 78,79 .

Dandelion greens, 87 . cooked, 34.

Dates, dried, 37, 92.

Desserts, $42,43,44,45,46,47$, $48,49,50,84,85$.

Diet, regulation of, 15 .

Digestibility, 6 .

Distilled liquors, 58, 59.

Doughnuts, 47, 84.

Drop cake, 84 .

Duck, breast, 71 .

giblets, 71 .

meat, 71 .

"Edible portion," 1.

Educators, 39.

Eels, salt-water, 73.

Egg crackers, 83.

Eggnog, 55.

Egg plant, 87.

Egg sandwich, 39, 97.

Egg souffle, 48.

Eggs, 33, 77.

boiled, 33,77 .

Entire wheat flour, 81.

Equivalents, table of, 24.

European malt liquors, 61 .

European wines, 60.

Export beer, 61.

Farina, 81 . cooked, 40.

Fats, 1, 2.

Figs, dried, 37, 93.

fresh, 90 .

stewed, $37,93$.

Filberts, 53, 95. 
Fish, cooked, 29.

fresh, $73,74,75$.

preserved and eanned, 75, 76.

Floating island, 48.

Flounder, 73.

Flour, 79, 80, 81.

Food requirements in health, 13.

with mental work, 13.

with muscular work, 11.

Food stuff, elassification of, 1.

Food values, method of calculating, 5, 19.

Foods, cooking of, 16. uses of, in body, 3 .

Force, 40.

French dressing, 51.

French red wine, 60.

French white wine, 60.

Frosted eake, 42, 84 .

Fruit, canned, 93, 94. dried, $37,92,93$. fresh, 36, 90, 91, 92. stewed, 37 .

Fruit cake, 42, 84 .

Gelatin, 79.

Gin, 58.

Gingerbread, 42, 84 .

Ginger snaps, 48,84 .

Gluten bread, 38,82 .

Goose, breast, smoked, 72 . giblets, 71.

gizzard, 71 .

liver, 71 .

meat, 71 .

Gooseberries, 36.

Graham bread, $38,82$.

Graham erackers, 39, 83.

Graham flour, 81.

Grapefruit, 36.

Grapenuts, 40.
Grapes, 36, 90.

Green goose, giblets, 71 . meat, 71 .

Green peas, canned, 89.

Green turtle soup, canned, 31, 97.

Guinea hen, giblets, 71 . meat, 71 .

Haddock, 74. cooked, 29. smoked, 75 .

Hake, 74 .

Halibut, cooked, 29. smoked, 75 .

steaks, 74 .

Ham, boiled, smoked, 28, 69. cooked, luncheon, 69. fresh, 68 . fried, smoked, 28,69 . smoked, 69.

Ham salad, 97.

Ham sandwieh, 39.

Hash, 26, 97.

Hens' eggs. See Eggs.

Herring, 74 . smoked, 75 .

Hickory nuts, 95.

H-O, boiled, 41 .

Hollandaise sauce, 52.

Hominy, 80. cooked, 41, 80 .

Honey, 53, 85.

Horse-radish, 89.

Huckleberries, 36, 91.

Iee cream, 48 .

Indian-meal mush, 41.

Indian-meal pudding, 45, 85 .

Isinglass, 79 .

Jellies, 37, 93.

Julienne soup, canned, 31, 96. 
Koumiss, 32, 78.

Kümmel, 59.

Ladyfingers, 49, 84 .

Lager beer, bottled, 61 . draft, 61 .

Lamb, 27, 66, 67. breast, 66 . ehops, broiled, 27, 67 . forequarter, 67 . fresh, 66,67 . hindquarter, 67 . leg, 66. roast, 27,67 . loin, 66. neck, 66 . shoulder, 67 . side, 67 .

tongue, spiced and cooked, 67.

Lard, refined, 49.

Lemon juice, 91.

Lemon pie, 42, 85 .

Lemonade, 55, 56. egg, 55. with white of egg, 55 .

Lemons, 36, 91.

Lentils, dried, 87 .

Lettuce, 87.

Lichi nuts, 95.

Light beer, 61 .

Lima beans, 86 . eanned, 89. cooked, 34 . dried, 86.

Liqueurs, 59.

Lobster, 30, 76. eanned, 77 .

Macaroni, 81. baked with cheese, 41 . cooked, 41, 81 .
Macaroons, 49, 84.

Mackerel, 74. cooked, 29. salt, 75 .

Spanish, 29, 75.

Madeira wine, 60.

Malaga wine, 60.

Malt liquors, 61.

Malted milk, 56 .

Maple sirup, 53, 86.

Maple sugar, 53, 86.

Marmalade, orange, 37, 93.

Marsala wine, 60.

Mayonnaise dressing, 52.

Meals, 79, 80, 81 .

Meat stew, 31, 96.

Meats, 26.

Mellin's food, 56.

Milk, 33, 79.

Milk gruels, 40 .

Mincemeat, 97 .

Mince pie, 43, 85 .

Mineral matter, 1, 2 .

Miscellaneous sweets, 53.

Mock-turtle soup, canned, 31 , 96.

Molasses, eane, 85.

Molasses cookies, 49, 84 .

Moselle and Saar wine, 60 .

Mulligatawny soup, eanned, $31,96$.

Munich heavy beer, 61 .

Mushrooms, 35, 87.

broiled on toast, 35 .

Muskellunge, 74 .

Muskmelon, 91.

Mussels in shell, 76.

Mutton, 28, 67, 68.

boiled, lean, 28.

chop, lean, 28.

ehuck, 67.

lean, 67 . 
Mutton, flank, 67.

forequarter, 67 .

heart, 68.

hindquarter, 68.

kidneys, 68.

leg, 67 .

roast, 28,68 .

liver, 68 .

loin, 67 .

neck, 67 .

shoulder, 67 .

side, 68 .

Nectarines, 91.

Nonalcoholic beverages, 54,55 , 56.

Noodles, 81.

Nuts, 53, 54, 94, 95.

Oatmeal, 80. boiled, 41,80 .

Oatmeal erackers, 39, 83.

Oatmeal gruel, 41, 80.

Oatmeal water, 80 .

Okra, 87 .

canned, 89.

Oleomargarine, 79.

Olive oil, 52.

Olives, green, $52,89$. ripe, 89.

Omelet, 33.

Onions, cooked, 35,87 .

fresh, 87.

Orange ice, 49.

Orange marmalade, 37, 93.

Oranges, 36, 91.

Overfeeding, 14.

Oxtail soup, canned, 31, 97 .

Oyster crackers, $39,83$.

Oyster stew, 30.

Oysters, canned, 77 .

in shell, 30,76 .
Parsnips, 87. cooked, 35 .

Pastry, 42, 84, 85.

Pea soup, eanned, 31, 97. eream of, $31,97$.

Peaches, 36, 91. canned, 93.

Peanut butter, 95.

Peanuts, 53, 95.

Pears, 36, 91. canned, 93. dried, 93.

Peas, dried, 87. green, 35,87 . canned, 89. cooked, 35.

Pecans, 54, 95.

Perch, white, 74 . yellow, 74 .

Persimmons, 91.

Pheasant giblets, 71 . meat, 71 .

Pickerel, 74 .

Pickles, cucumber, 89. mixed, 90. spiced, 90.

Pies, 42, 43, 85.

Pigeon giblets, 71 . meat, 71 .

Pigs' feet, 68. pickled, 69.

Pigs' tongues, pickled, 69.

Pike, gray, 74.

Pilot bread, 39, 83.

Pilsen export beer, 61 .

Pineapples, 36, 92. canned, 94.

Pistachios, 54, 95.

Plums, 36, 92.

Pomegranates, 92.

Pompano, 74.

Pop corn, 80. 
Porgy, 74.

Pork, 28, 68, 69, 70. chops, 68.

cooked, 28.

ehuck ribs and shoulder, 68 . fat, salt, 69 .

feet, 68 .

middle cuts, 68 .

roast, 28 .

sausage, 28.

side, 68 .

shoulder, 68 .

steak, cooked, 69 .

tenderloin, 68 .

Port wine, 59, 60.

Porter, 61.

Potato soup, cream of, 31 .

Potatoes, sweet, 88 . boiled, 35,88 .

white, 87 .

baked, 35 .

boiled, 35, 87 .

chips, 35,87 .

creamed, 35 .

mashed and creamed, 35, 88.

Poultry, fresh, 70, 71, 72. meat, preserved, 72,73 .

Preserves, 72, 73, 93, 94.

Pretzels, 39, 83.

Protein, 1, 12.

Prune sauce, 37, 94.

Prune souftlé, 49.

Prunes, 92.

dried, $37,93$.

Puddings, 43, 85.

Puffed rice, 41.

Pumpkins, 88.

canned, 89.

Q:a ail giblets, 72 .

meat, 72 .
Radishes, 88 .

Raísins, 37, 93.

Raspberries, 36, 92.

dried, 93.

Raspberry juice, 92.

Red grouper, 74 .

Red snapper, 74 .

Refuse, 1.

Rhein wine, 60 .

Rhubarb, 88 . stewed, 37.

Rice, 80.

boiled, 41, 80 . flaked, 80.

Rice custard, 44, 85 .

Rice flour, 80 .

Rolled oats, 80 .

Rolls, 38, 82 .

French, 38, 82.

Vienna, 38, 82.

Rum, 59.

Rye bread, 38,82 .

Rye flour, 80 .

Rye meal, 80.

Salmon, 74.

California, 74 .

canned, 75.

cooked, 29.

landlocked, 74.

Saltines, 39, 83 .

Salts, 1.

Sandwiches, 39.

Sardines, canned, 29, 76.

Sauces, 50, 51, 52 .

Sauerkraut, 88.

Sausage, 69, 70.

Arles, 69.

banquet, 69 .

Bologna, 69.

farmer, 69 .

Frankfort, 69. 
Sausage, Holsteiner, 69.

Lyons, pure ham, 69. pork, 69.

Salmi, 70.

Wienerwurst, 70.

Scalloped oysters, 30 .

Scallops, 76.

fried, 30 .

Scraped beef, 26.

Shad, 74 . roe, 75 .

Sheepshead, 75 .

Shellfish, 29, 76, 77 . eanned, 77 .

Sherry, 59, 60.

Shredded wheat, 41, 81 .

Shrimp, canned, 77.

Skimmed milk, 33, 79.

Smelt, 75 . cooked, 29.

Snow pudding, 45.

Soda biscuit, 38, 82 .

Soda erackers, $39,83$.

Soft eustard, 45.

Soups, 30, 96. canned, 97.

Spaghetti, 81 . baked, with tomatoes, 42 .

Spanish cream, 50.

Spanish mackerel, $\mathbf{7 5}$. broiled, 29.

Spinach, 88. cooked, 35, 88.

Sponge cake, $42,84$.

Squab giblets, 72 . meat, 72 .

Squash, 88 . canned, 89. cooked, 35 .

Squash pie, 43, 85.

Steak, porterhouse, 63. round, 27,63 .
Steak, sirloin, 63. tenderloin, 27, 63.

Strawberries, 36, 92. canned, 94.

Sturgeon, 75 .

Suceotash, canned, 89.

Sugar, 53, 85, 86.

brown, 85 .

cube, 53.

domino, 53.

granulated, 53, 85 .

maple, 53, 86 .

powdered, 53,86 .

Sugar cookies, 49, 50, 84 .

Sweet wines, 59, 60.

Sweetbreads, 27.

Tallow, 79 .

Tapioca, 85. and apples, 46, 85 .

Tapioca pudding, 46,85 .

Tea, 54.

Terrapin, 76.

Toasted bread, 38,82 .

Tokay wine, 60 .

Tomato catsup, 51, 89.

Tomato preserve, 94 .

Tomato soup, eanned, 31, 97. eream of, 31 .

Tomatees, 35, 88. canned, $35,89$.

Tomeod, 75 .

Tongue, canned, 27, 65 .

Tripe, piekled, 65.

Trout, brook, 75 .

cooked, 29. salmon, 75 .

Turbot, 75 .

Turkey, 72. dark meat, 72 . cooked, 72 .

giblets, 72 . 
Turkey, gizzard, 72.

heart, 72 .

light meat, 72. cooked, 72.

liver, 72. potted, 73 .

roast, 28.

sandwich, eanned, 73 . young, 72 .

Turnips, 88.

cooked, 35 .

Turtle, green, 76.

Underfeeding, 14.

Uneeda biseuit, 39 .

Veal, 28, 65, 66. breast, 65 . ehuck, 65 . cutlet, 28. flank, 66 . forequarter, 66 . heart, 66 . hindquarter, 66 . kidneys, 66.

leg, 66 .

liver, 66. loin, 66 . lungs, 66. rib, 66 .

roast, 28. rump, 66.

shank, 66 . shoulder and flank, 66.

Vegetable soup, canned, 31, 97. Vegetables, 34, 35, 86, 87, 88, 89.
Vegetables, canned, 88, 89. cooked, 34, 35.

Vermicelli, 81 . boiled, 42 .

Wafers, 84 .

Walnuts, 54, 95.

Water, 13.

Water crackers, 83.

Watermelon, 36, 92.

Weakfish, 75.

Weights and measures, table of, 25.

Weissbeer, 61.

Wheat, eracked and erushed, 81.

flaked, 81 .

Wheat bread, 38,82 .

Wheat flour, 81 .

Wheat gems, 81 . boiled, 42 .

Wheat glutens, 81 .

Wheat preparations, 81 .

Whey, 33, 79.

Whipped eream, 32.

Whiskey, 59.

White bread, 38, 83.

Whitefish, 75 .

Whole-wheat bread, 38, 83 .

Wine sauce, 52 .

Wines, 59, 60.

Yeast, compressed, 95.

Zephyrs, 39.

Zwieback, 38, 83. 


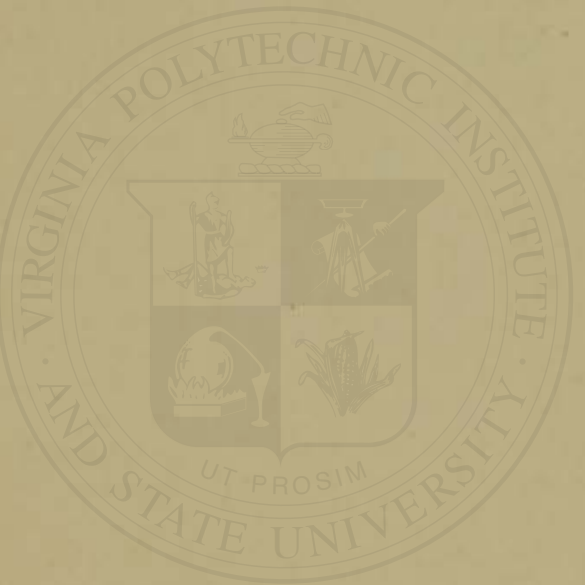




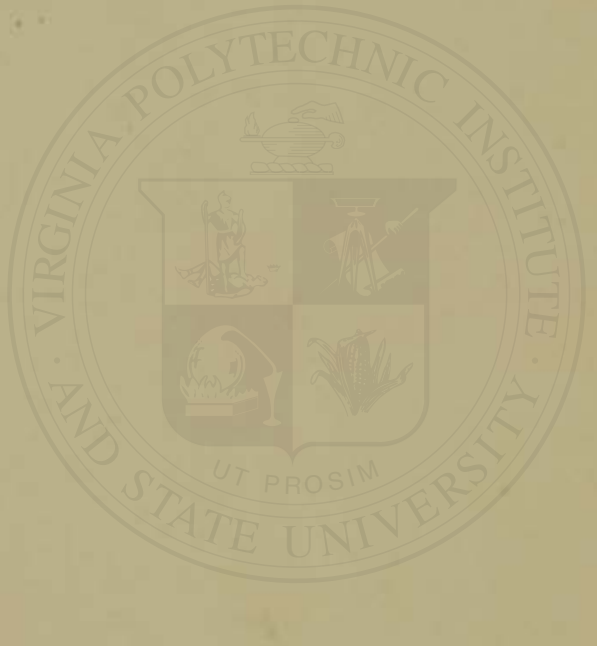




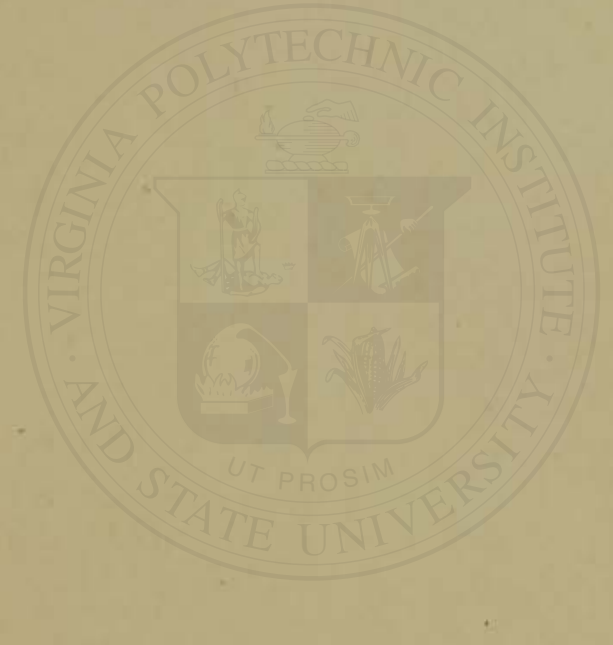




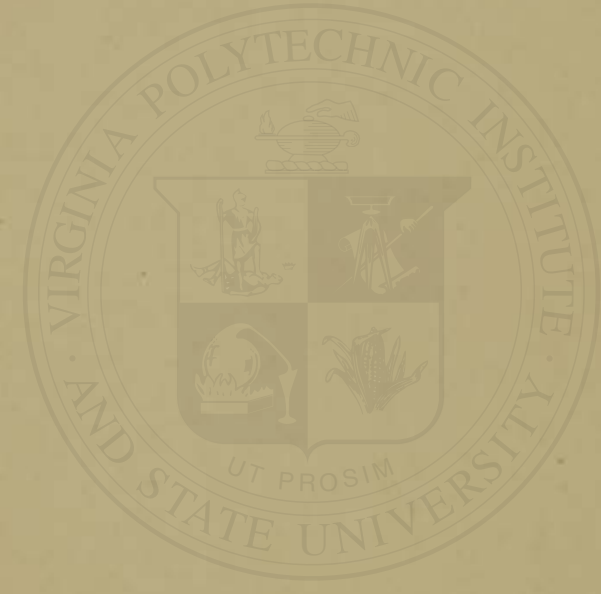




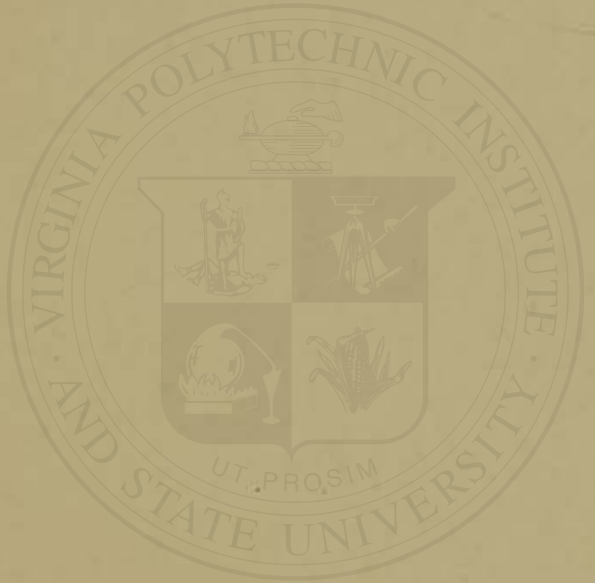


